\title{
わが国の住居暖房と暖房用燃料の 現状ならびに問題点*
}

\author{
一昭 和 42 年 9 月 7 日 受 理一
}

\section{I. 総 論}

I . 1 わが国における住居暖房の考え方

冬期に暖房を行ない，仕專の能率をあげることの必 要性は, わが国に拉いても大分以前より認められ, 事 務所, 事業所などではすでにかなり進歩した暖房設備 が備えられている。しかし一般の家庭では暖房, すな わち部屋全体を暖める, といら考え方はあまり進んで いないといらのが従来の通説であつた。これは一部の 地方をのぞき，わが国の冬期の気温があまり低くない こと，家屋構造が暖房に適していなかつたことがあげ られるが，同時にアメリカ, 西欧とくらべて, 生活程 度の点などから冬期の住居内の生活をもつと快適にす るといらことが実行できなかつたことにもよる。

そのかわり，わが国では，かいろ，こたつなど身体 の一部をあためて寒気を防ぐといら方法はかなり進歩 していた。これは暖房に対し暖身とでも呼ばれるべき ものであろう。比較的最近までわが国における冬期の 暖のとり方にはこのような特色があつた。

I.2. 暖身から暖房への転回

最近10年間にわが国の家庭の暖房といわれるもの は, その形式上からを, 使用燃料の点からも急激な変 化を示した。堀りごたつの一般化, 電熱利用の增加, 木炭使用の激減，などの現象があるが，その中でも最 も大きな影響を与えたものはポータブル式石油ストー ブの爆発的な普及であろら。

この石油ストーブは後に述べるごとく完全な意味で の暖房設備には遠いものであるが, わが国の家屋構造 に比較的よく適合し，火鉢にかわりそれより暖房效果 の高いものとして広く用いられるよらになつた。これ がわが国に就ける住居の暖房に詨する考え方の変化の

* Survay of the Present Status of Domestic Heating in Japan and its Problems.

** Subcommittee on the Combustion of Domestic, Fuels, Division of Combustion, Fuel Society of Japan.
燃料協会家庭燃料の燃燒小委員会**

契機となつたように思われる。

ポータブル式石油ストーブは単なる手あぶりにすぎ ないともいわれるが，外気温度があまり低くないとき は暖房として十分効果を㐫げることができる。一方本 報告でのベるようにこの石油ストーブは家庭用の暖房 設備として種々の問題点を持つている。そしてもしそ の理由でこのストーブの使用をやめるとすれば,つぎ にはもつと完全な意味での暖房設備を欲求するように なるのは当然の勢であろう。

I . 3. 所得水準と住居暖房形式の関係

家庭において部屋全体あるいは家屋全体を暖房する ことは考えてみれば一種のぜいたくである。したがつ て何らかの計算にもとづいてその使用がきまるわけで はない。しかし所得の増加にともなつて暖房に使用す る熱量も増加するといら傾向は明らかにみられる*。 石油ストーブや電気暖房器具の使用の増加はわが国の 国民所得の伸びと無関係ではない。

国民所得が現在の伸び率で増加し，生活程度が向上 すればわが国の住居暖房が一般的に現在よりさらに 進んだ形式のものに変わる可能性は十分にある。外国 の例をそのままわが国にあてはめることはできない が，西欧諸国においてもそのような意味の住居暖房の 革新が比較的近い過去に㧍いておこり, 現在もそれが 進行しているようである。西欧諸国の国民所得の水準 がわが国より数歩先んじていることを考えれば，この ことはわが国の住居暖房の将来を考えるとき大いに参 考になるものと考えられる。

I . 4. 住居暖房の現状認識とその将来像

わが国の住居暖房の形式が将来どのように変化し， 使用熱量がどの程度增加するかは，然料供給者，家庭 䁔房器具製造者にとつて直接関係のある問題である。 また建築関倸者, さらに消費者で㐫る一般家庭でも, 十分関心があるであるう。しかしとくに直接関係のあ る企業としては単なる推論や外国の例のひきうつしに よる予想で将来計画をたてることは危険であろう。 
将来を予測するためには現状に関するできるだけ正 確な情報をあつめ，それを分析し，さらに外国の例安 参考にして十分根拠の亦る予測索行晾う必要がある。 本報告は小委員会においてまとめられた住居暖房の現

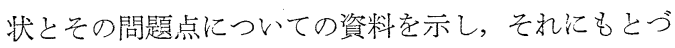
いて若干の分析を行なつたものである。これが各方面 の関係者の参考となり,このような調査を発展させる 契機となれば幸である。

\section{II. わが国の家屋構造と住居暖房の方式}

II. 1. 住居としての家屋構造の現状とその変遷

III. 1.1 家屋構造の変遷

（1）従来の和風木造住宅

わが国の和風木造住宅は，南方民族の系統のもの で,われわれの祖先が南方から持つてきたものと考え られる。すなわち古い神社にみられるように床が高 く, 部屋の周囲注すつかりあけ放たれて，外側に縁を めぐらして晾り，屋根は高く組み上げられている。こ れは南方の暑くじめじめした地方に適した形式で風通 しがよくて涼しく，しつけないことを主とした建て方 である。このような建物は, 時代の移り変わりと生活 様式の変化汇ともなつて次第に発展し, 明治以後は洋 風住宅の影響も受けてはいるが，北欧や英国風のレン ガ造の住宅に比べれば，はるか開放的である。

室内気候的にみた和風木造住宅の特徴としては, つ ぎの諸点をあげることができる。

(a) 開口部が非常に大きく換気量が多いこと。

（b）外面した壁，建具などの熱担抗が小さいこ と。

（c）屋根汸日射による熱侵入にたいして比較的抵 抗が大きいこと。

（d）ひさしが深く日射が室内に入ることを防いで いること。

（e）建物の熱容量が小さいこと。

以上のことからわかるように，和風木造住宅夏に 涼しくすることを主として考えたものであつて，日射 による熱唚入を防ぎ，通風をよくして適当な気流をた もち，また熱容量が小さいから昼間に建物が受けた熱 が夜間に室内に放散されることもなく, 夜は涼しい夜 気をたのしむことができる。しかし一方，冬はすき間 風が多く, 周壁や建具の保温が不十分であつて室を暖 ためることは不可能である。したがつて従来はわが国 では暖房はあきらめて，こたつやいらりなどで，もつ ぱら身体を暖める(暖身)ょうにしていたのである。

(2) 最近の洋風木造住宅

最近の建築技術と建築材料の准歩は, わが国の住宅
の形式を次第に変えつつある。よい断熱材料や気密な 建具の開発によつて, 徒来通り夏に涼しい特徴を生か しながら，冬には十分暖かく暖房のできる住宅が生ま れている。

こ礼らの特性は

(a) 熱容量が小さいこと。

（b）換気量は和風木造往宅に比べて小さい。

（c）屋根が鉄板ぶきやスレートぶきなどの熱抵抗 の小さい場合が多い。

（d）一般に空面積が大きい。

建物の熱容量が小さいので, 室内温度の変化がはげ しい。しかし金属製のサッシュが用いられているの で，一般の木造住宅に比べて換気量が小さく，また壁 の断熱も比較的よいので暖房しやすい。ガスストーブ など用いるとすぐ暖かくなる。

（3）コンクリートアパート

わが国には戦後多くのコンクリートアパートが建設 されているが，その熱的性質はかなり徒来の和風木造 住宅とはちがつている。その特徵をあげると，つぎの 諸点である。

(a) 換気量が非常に小さいこと。

（b）外壁の面積が小さいこと。

(c) 熱容量が大きいこと。

以上のことからわかるように，住宅全体として熱損 失が少なく，かつ熱容量が大きいために室温の変動が 緩慢であって，これまでは一般庶民の住宅では行なわ れていなかつた室全体を暖めることが，それ程の費用 をかけないで行なえるようになつた。

II. 1. 2. 気密性の向上

（1）サッシュの改良

従来の和風木造住宅の自然換気は, 空, 出入口など の開口部ばかりでなく，天井，壁のすき間，らんまな ぞの多くのすき間によつて行なわれていた。しかし， 最近の住宅では，天井，壁などのすき間はほとんどな くなり, 自然換気の行なわれるすき閒は, 大部分建具 のすき間である。

建具には，木製のものと，鉄またはアルミニウム製 のものがあるが，木製の建具はくるい易く，すき間が 大きくなり易い。鉄やアルミニウム製のものは，建具 だけででなく，枠組も一緒にして，いわゆるスチール サッシュやアルミニウムサッシュとして市販されてい る。これらは, 非常にすき閏が少なく, 木製のものに 比して格段と気密性が向上している。とくに気密サッ シニと呼ばれて市販されているものは，ほとんどすき 間風が大らない。 
(2) サッシュの透気量

各種のサッシュの誘気、量を图1 亿示す。

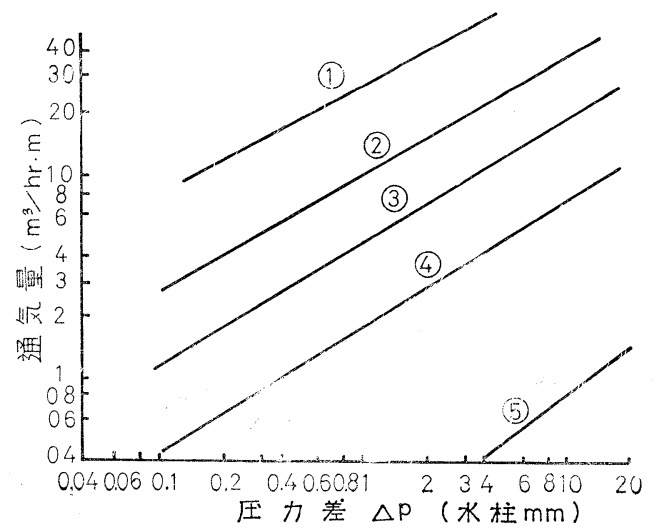

(1)木製サッシュ（引違い）(2)金属サッシュ（引違 い）(3)金属製気密サッシュ（モへア付）（引違い） (4)金属性製気密音ッシュ（こヘア付）（上下片引 き,開き戸)

図 1 すき間 $1 \mathrm{~m}$ 当たりの通気量

実際の建物に打ける自然換気は, 外界の風の圧力に よるものと, 室内外の温度差で生じた圧力差によるも のとがあるが，いくらか風のあるときは，風圧力によ る換気量の方が温度差による換気量よりも大きい。し たがって暖房計算には，風圧による換気量を計算すれ ばよい。

建物の風上側と風下側に大体同程度のサッシュがあ るとして, 室内外の圧力差を

$$
\Delta P=0.6 \frac{\rho}{2 g} v_{2}
$$

$v:$ 外気風速 $(\mathrm{m} / \mathrm{sec})$

$\rho:$ 空気密度 $\left(\mathrm{kg} / \mathrm{m}^{3}\right)$

$g:$ 重力の加速度 $\left(9.8 \mathrm{~m} / \mathrm{sec}^{2}\right)$

で求め, 図1とサッシニのすき間の長さから, 換気量 $Q$ が計算できる。

図 2 は, 各種の建具を有するコンクリートアパート の換気量である。また, 各種の住宅の自然換気量の大 体の見当は，表1亿示すとおりである。

\section{表 1}

室の種 類 コンクリートアパート 木造大壁造洋室 木造真壁和室(従来のもの)

" (やや気密なもの) 内外壁板張り洋室 $\underset{(\mathrm{m} / \mathrm{sec})}{\text { 速 }}$ 自然換気回数

$$
3 \sim 5 \quad 0.6 \sim 2.0
$$

$" \quad 1.0 \sim 3.0$

" $\quad 2.0 \sim 10.0$

" $\quad 1.0 \sim 5.0$

" $\quad 1.0 \sim 5.0$

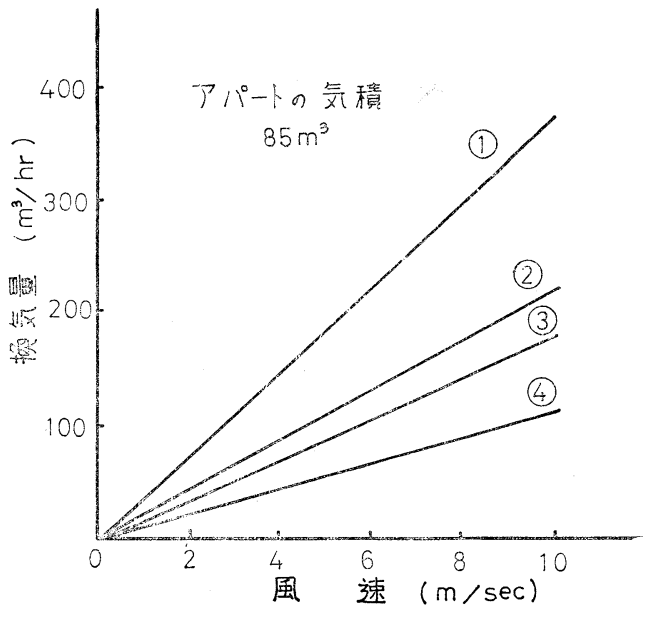

(1)木製建具（建具普通のもの) (2)木製建具（建具 のよいもの) (3)金属サッシュ（普通）(44金属サッ シニ（気密）

図 2 コンクリートアパートの換気量

II. 1. 3. 壁, 床, 屋根などの断熱性の向上

(1) 断熱材の開発

戦前は建物の保温に用いられていた断熱材は，炭化 コルク，牛毛フエルトなどに過ぎず，冷凍倉庫などの 特殊な建物にしか用いられていなかつた。戦後, 非常 に優秀な断熱材が数多く開発され, 価格も安くなつた ためにほほとんどすべての住宅に断熱材が使用されて いる。断熱材の主要なものはつぎのとおりである。

(a) 軟質せんい板

軟質せんい板は，植物せんいを原料として作られた ものでインシュレーションボードとも呼ばれ，A級 とB級とに分けられる。B 級はテックスとも呼ばれ る。A 級注吸水量が少なく断熱性は非常によい。

（b）岩綿（ロックウール）

蛇敘岩などを高温で溶かしてせんい状にしたもの で，断熱材として広く用いられている。皮膚にささる ので使いにくい難点があるが最近はせんいが細く使い 易いものもできている。防火性のあるのが特長であ る。

（c）ガラスせんい

ガラスを溶かしてせんい状にしたもので, 断熱性は 非常によく, 不然性であり, また作業性もよいので広 く用いられている。最近せんい径が細くなり，これを レジンで焼付けて弾力性のあるマット状にしたものが 多く用いられている。

(d) 発泡プラスチック

近年, プラスチックの発泡体が断熱材として建築の 
分野に現われてきた。施工性のよさと断熱性能の優秀 なために，価格は幾分高いにもかかわらず非常に多く 使われている。耐熱性や防火性の乏しいことが欠点で ある。

その主要なものは, ユリヤ系, 塩化ビニル系, ポリ
ウレタン系，スチロール系などで，スチロール系のも のは安価であるから一番多く用いられている。現場発 泡の必要なときは，ユリヤ，ポリウレタンが使用され る。

表 2 に各種の材料の断熱性能 (熱伝導率) を示す。

\section{表 2 各種材料の熱特性}

\begin{tabular}{|c|c|c|c|c|c|c|}
\hline 料 & $\begin{array}{l}\text { 密 度 } \rho \\
\left(\mathrm{kg} / \mathrm{m}^{3}\right)\end{array}$ & $\begin{array}{c}\text { 比 熱 } c \\
\left(\mathrm{kcal} / \mathrm{kg}^{\circ} \mathrm{C}\right)\end{array}$ & $\begin{array}{l}\text { 温 度 } \\
\text { 顀率 } \\
\left(\mathrm{m}^{2} / \mathrm{hr}\right)\end{array}$ & $\begin{array}{l}\text { 熱伝導率 } \lambda \\
\mathrm{kcal} / \mathrm{m} \mathrm{hr}{ }^{\circ} \mathrm{C}\end{array}$ & $\begin{array}{c}\text { 熱伝導 } \\
\text { 比抵抗 } \\
1 / \lambda\end{array}$ & 温 \\
\hline 軽 量 コンクリ一ト (1) & 1,720 & & & 0.58 & 1.73 & \\
\hline 㪕 量 コンクリート (2) & 800 & & & 0.23 & 4. 35 & \\
\hline 気泡コンクリート (1) & 767 & & & 0.16 & 6.25 & $\lambda=0.148+0.00028 \theta$ \\
\hline 気 泡 コンクリート (2) & 718 & & & 0.11 & 9.1 & $\lambda=0.095+0.00031 \theta$ \\
\hline パーライトモルタル & 619 & & & 0.09 & 11.1 & $\lambda=0.087+0.00019 \theta$ \\
\hline 気 泡 コンクリート (3) & 589 & & & 0.14 & 7.2 & $\lambda=0.125+0.00036 \theta$ \\
\hline 気泡コンクリート (4) & 500 & & & 0.11 & 9.1 & $\lambda=0.087+0.00030 \theta$ \\
\hline 気 泡コンクリート (5) & 433 & & & 0.10 & 10.0 & $\lambda=0.095+0.00018 \theta$ \\
\hline 板 状岩綿 (1) & 720 & & & 0.10 & 10.0 & \\
\hline 繊維板 & 494 & & & 0.014 & 71.4 & \\
\hline 綿状岩 綿 (1) & 350 & 0.20 & 0.00095 & 0.038 & 26.4 & \\
\hline 板 状 岩 綿 (2) & 330 & 0.20 & 0.0008 & 0.053 & 18.9 & $* \lambda=0.0482+0.00023 \theta$ \\
\hline 綿 状 岩 綿 (2) & 300 & & & 0.052 & 19.3 & \\
\hline 板状岩綿 (3) & 257 & & & 0.042 & 23.8 & \\
\hline 綿状岩綿 (3) & 240 & & & 0.046 & 21.7 & \\
\hline 板 状 岩 綿 (4) & 230 & & & 0.053 & 18.9 & \\
\hline 綿＼cjkstart状＼cjkstart岩＼cjkstart綿 (4) & 200 & 0.20 & 0.00095 & 0.038 & 26.3 & $* \lambda=0.035+0.00014 \theta$ \\
\hline 炭 化 コルク & 135 & & & 0.045 & 22.2 & \\
\hline 多泡 ポリスチレン (1) & 113 & & & & & $\lambda=0.035+0.00010 \theta$ \\
\hline コ ル ク 板 & 100 & 0.4 & 0.00072 & 0.036 & 27.8 & $* \lambda=0.035+0.00004 \theta$ \\
\hline 多泡 ポリスチレン (2) & 81 & & & & & $\lambda=0.029+0.00009 \theta$ \\
\hline 多 泡 ポリスチレン (3) & 54 & & & & & $\lambda=0.017+.000012 \theta$ \\
\hline 多 泡 ポリスチレン (4) & 33 & & & & & $\lambda=0.029+0.00015 \theta$ \\
\hline ガ ラ ス 綿 (1) & 16 & & & 0.031 & 32.5 & $\lambda=0.026+0.00018 \theta$ \\
\hline ガ ラ ス 綿 (2) & 12 & & & 0.036 & 27.7 & $\lambda=0.030+0.00019 \theta$ \\
\hline 多 泡 ポリスチレン (5) & 11 & & & & & $\lambda=0.028+0.00014 \theta$ \\
\hline ガ ラ ス 綿 (3) & 8 & & & 0.036 & 27.4 & $\lambda=0.031+0.00023 \theta$ \\
\hline
\end{tabular}

（注） *印は防寒構造 “材料の温度 $t$ と熱伝導率 $\lambda$ の割増の $\beta \%$ 関係”から逆算により求めたものである。

\section{(2) 壁の断熱}

壁の断熱をよくするには，断熱特性のよい（熱伝導 率の小さい）材料で厚い壁を作ればよいが，また壁の 中間に空気層を作ることも非常に有効である。たとえ ば，下見板だけの壁は断熱が悪く, 熱貫流率 (温度差 $1^{\circ} \mathrm{C}$ のとき, $1 \mathrm{~m}^{2}$ の壁から 1 時間に逃げる熱量) は
3.8 であるのに, 中空層を設けてベニヤ板を張ると, 3.0 に減る。できれば，中空層に断熱材を㣣むと非常 によくなる。図 3 によると $2.5 \mathrm{~cm}$ の岩綿を挾むと， 熱貫流率が $1.0 \mathrm{kcal} / \mathrm{m}^{2} \mathrm{hr}{ }^{\circ} \mathrm{C}$ になる。空気層にアル ミ䇴が熱放射を防止するので，これも断熱に役立 つ。 


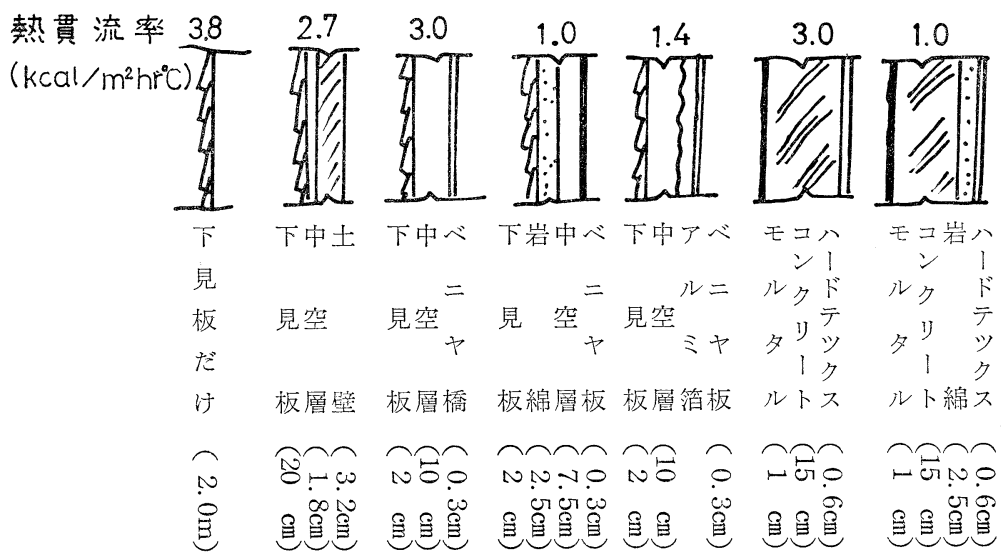

図 3 各種の壁の断熱性の比徬

\section{（3） 屋根の断熱}

屋根だけで天井がないと，断熱が十分でない。とく に鉄板ぶきの屋根の断熱は非常に悪い。天井をはると 断熱性が相当に向上する。たとえば木造のかわら屋根 の場合, ベニヤ板で天井を張ると, 張る前に比べて逃 げる熱量は 7 割ぐらいに減る。屋根の断熱をよくする ことは，冬だけでなく夏に凉しくするためにも大変有 効であるから，必ず実施するようにしたい。図４に示 すように，天井裏に断熱材を敷きつめると一層よい。

屋根に天井のあるときは，屋根裹の換気があるの で, 総合的な熱貫流率を求めなければならない。

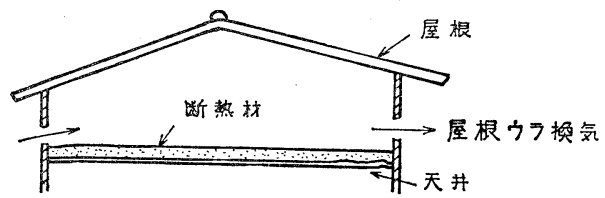

図 4 天井の断熱

（4）床の断熱

たたみは非常に断熱がよい。板張りの床は二重張り にして，その間に断熱材を入れる。じゆうたんを敷く のも断熱効果がある。

表 3 に各種の液の熱貫流率を示す。

\section{表 3 表各種の床の熟貫流率}

構造 $\quad\left(\mathrm{kcal} / \mathrm{m}^{2} \mathrm{~h}{ }^{\circ} \mathrm{C}\right)$

\begin{tabular}{|c|c|}
\hline $\begin{array}{l}\text { コンクリート } 15 \mathrm{~cm}, \text { 岩綿 } 6 \mathrm{~cm}, \\
\text { 椽甲板 } 1.4 \mathrm{~cm}, \text { リノリウム } 0.5 \mathrm{~cm}\end{array}$ & 0.45 \\
\hline $\begin{array}{l}\text { コンクリート } 15 \mathrm{~cm} \text {, 中空層 } 6 \mathrm{~cm} \text {, } \\
\text { 床板 } 1.2 \mathrm{~cm} \text {, たたみ } 6.1 \mathrm{~cm}\end{array}$ & 0.73 \\
\hline 板 $1.2 \mathrm{~cm}$ ，たたみ 6 . & 1.0 \\
\hline 反. $1.4 \mathrm{~cm}$ ，リノリウ & 2.05 \\
\hline
\end{tabular}

III. 2. 住宅暖房の諸形式

II. 2. 1 . 設計温度

住宅においては，人間が生活するのに最も健康的で 快適な温度に保持すれ将よいのであるが，居間，台 所，玄関などは，その使用状態ならびに人の生活状態 が異なつているために，適当な温度に相違がある。こ れを表 4 に示す。

\section{表 4}

用途

$\stackrel{\left.\text { 適 }{ }^{\circ} \mathrm{C}\right)}{\text { 温 }}$
$16 \sim 20$
$12 \sim 14$
$15 \sim 17$
$18 \sim 20$
$10 \sim 15$

居間あるいは食堂として使用する室

$16 \sim 20$

夜間就寝に使用する室

$2 \sim 14$

嘼房

$18 \sim 20$

洋式, 浴室, 水洗便所

$10 \sim 15$

この表は湿度が 40〜75\%，ほとんど無風(1.0 0.3 $\mathrm{m} / \mathrm{sec}$ ) の場合である。また人体に直接当たる気流 は，10〜 20cm/sec にとどめるようにし，天井と床の 温度差はなるべく小さくし， 5 $5^{\circ} \mathrm{C}$ 以ないほうがの ぞましい。

寝室は病気のときや，書斎・子供室などに転用する ときのことも考えて，居間なみに暖房できる手段を講 じておくことが望ましい。

厨房では各種の発熱作業が行なわれるから，どの程 度の熱負荷を考えたらよいかがはつきりしない。しか し発熱作業を行なわない場合にも十分なだけの容量を 設計負荷に見込んでおくのがよい。

外部設計温度は和風住宅や軽量鉄骨住宅は熱容量が 小さいから外気の最低温度を考えるべきであるが，コ ンクリート住宅では熱容量が大きいので割引きをして 
差支えない。

II. 2. 2. 各個暖房

各個暖房には，石炭ストーブ・煉炭ストーブ・ガス ストーブ・石油ストーブなどがあるが，然燒廃ガスが 室内に排出されるものは望ましくない。将来は，各個 暖房を用いるとしても，廃分スを屋外に出す種類のも のに変わることと思われる。この意味で，住宅に中央 暖房方式の装置を設けない場合には，必ず煙突をどこ に付けるかをあらかじめ計画しておく必要がある。

コンクリートアパートで永，在では各個に煙突を つけるのを禁じている場合が多いが将来は集合煙突を 考えておくべきであろう。

III.2.3.中央暖房

中央暖房とは，住宅の中央に熱源となる装置をもう
けて，住宅全体を暖ためる方法であつて，いろいろの 方式がある。

(1) ペーチカ

ペーチカは完全な中央暧房ではない多，建物を建て るときに設備しておくこと, 建物の比較的広い部分を 暧房するという意味で，中央煖痑に近いものといえ る。

円筒型，角型，壁型などの各種があり，構造はレン ガ積みのものが多いが，大型ブロックを使用したもの もある。レンガまた泣ブロックを暖めるふく射暖房の 一種であつて，一日中暖房を必要とする寒地にもいて いる。

困５は住宅にペーチカを用いた例定示す。

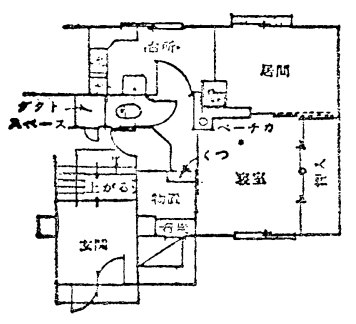

(a) アパートの留面

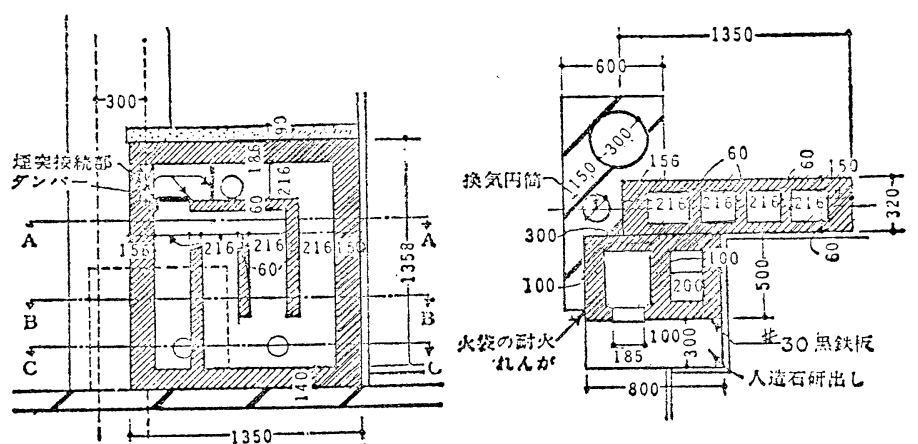

(b) ペーテカの紽断面（左）とB〜B断面（右）

図 5

\section{（2）温水暖房就よび蒸気暖房}

機械室に設置するポイラで温水また蒸気を作り， これを各室の放熱器に送る方式である。温水暖房は蒸 気暖房に比べて室内気候が温和で水の熱容量により循 環をとめてもなかなか冷えない利点がある。しかし放 熱器が大きくなることと凍結のおそれがある点などの 欠点もある。

放熱器としてベースボードヒーターがよく用いられ る。これは室の幅木の位置につけるもので, 既存の住 宅にもとりつけることができる（図6）。熱媒として は温水が最適で， $90^{\circ} \mathrm{C}$ 程度以上にすると上昇気流の ため壁がよごれるので注意を要する。空下や外に面し

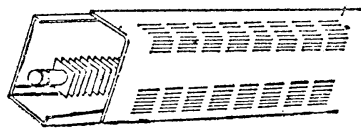

図 6
た壁に配置すれば冷たいドラフトが防げ，室内の温度 分布が均一になる。図 7 はその配置の一例である。

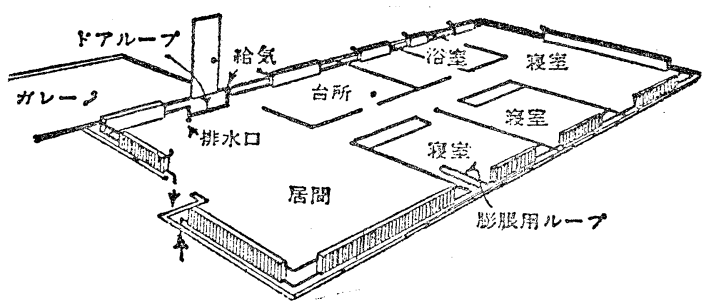

図 7

風炉

石油，ガス，石炭などで加熱した空気を送風機によ つて建物全体に送り暖房するもので，ダクトによつて 各室に送大する場合方多い。最近は住宅でも盛んに用 いられはじめている。 


\section{(4) パネル暖房}

床，天并，壁などを適当に加熱して，主としてそこ から低温ふく射によつて暖かさを得ようとするもので 建築全体と完全に組み合わされた建築化暖房とでもい らべきものである。パネル暖房の特長は，放射熱によ る感覚温度の上昇によりすぐれた快適性が得られ, 放 熱器がないので室内がきれいに保たれる。しかし床や 天井などの熱容量が大きいので 1 日中暖房するのには よいが，短時間の暖房や熱負荷の急激な変動には追從 できない。また建設費も高くなる。

多くは温水配管を床, 天井, 壁などに埋込んだもの であるが，電熱線を埋込んだり，温風ダクトを図 8 の よらに埋込んだものもある。朝鮮で用いられるオンド ルも床のパネル暖房の一種と考えてよい。
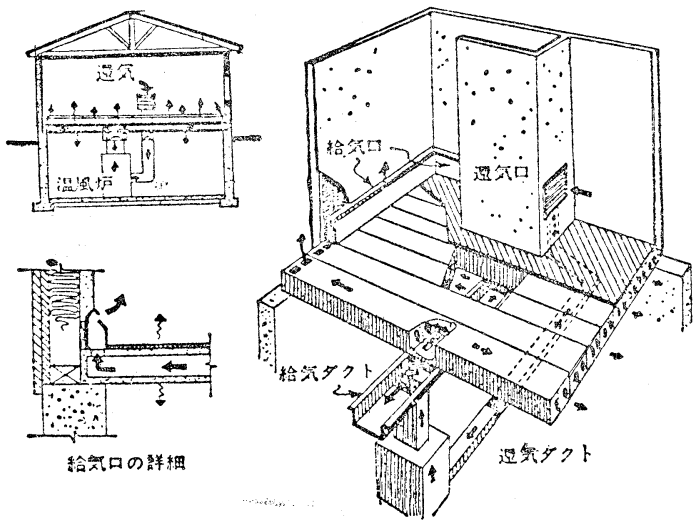

図 8

II. 2. 4. 地域暖房

アパートのよらにある地区に集団をなしている住宅 においては，地域暖房が考えられる。将来のコンクリ ートアパートの団地では地域暖房が主体となるである 5。

II. 3. 家屋構造と所要熱量

II . 3. 1. 所要熱量の算出法

暖房時の所要熱量の算出は, 一般には室内外の温度 は定常状態にあるものと仮定して行なら。実際には, 外気の温度は変動していて，その最低温度を外気温と して定常計算を行ならと, かなり安全側の所要熱量が 算出される。とくにコンクリート造の建物のように熱 容量の大きい場合には, 算出值と実際の所要熱量の差 が大きいので，いろいろの補正が行なわれる。

定常状態では，室内から外部に逃げる熱量はほぼ室 内外の空気の温度差 $t_{i}-t_{0}$ に比例するから, 単位時 間に室内に供給する熱量 $H$ は次式で示される。

$$
H=C\left(t_{i}-t_{0}\right)(\mathrm{kcal} / \mathrm{hr})
$$

ただし C は比例係数であつて，ほぼ常数を考えて 差し支えない。

室内から失われる熱量はつぎの三と㧍りのものに大 別することができる。すなわち第 1 は建物の周囲の 壁, 空, 出入口の扉, 天井, 床などの材料を熱伝導に よつて外部へ逃げるものである。これを貫流熱損失と いら。第 2 ののは，暖められた空気とともに直接に 建具や天井などの隙間, 換気口を通つて外気に出るも のである。これを掺気熱損失という。第 3 注などか らの熱ふく射による熱損失であるが，これは計算が困 難でありかつ熱量も少ないので, 無視して計算しな い。このほか暖められた建物の表面からのふく射によ る熱損失もあるが，普通湨流熱損失に含めて考它 る。

\section{（1）貫流熱損失}

\section{(a) 壁体からの熱損失}

壁体から定常状態において失われる熱量は，壁の熱 貫流抵抗がわかると計算できる。すなわち 1 時間に壁 体から流出する熱量 $H_{w}$ は

$$
H_{w}=\frac{A_{w}}{R_{w}}\left(t_{i}-t_{0}\right)(\mathrm{kcal} / \mathrm{hr})
$$

ただし $A_{w}$ は壁の表面積， $R_{w}$ は壁体の熱貫流抵抗 である。

（b）天井, 屋根加らの熱損失, 天井, 屋根加ら熱の 失われる経路は，まず室から天井をとおつて屋根裏に 熱が流れ，つぎに屋根裏から屋根をとおつて外に熱が 流れる。また一部は屋根裹の換気で空気とともに外に 流出する。天井，屋根からの熱の損失を知るために， 天井，屋根の総合熱貫流抵抗といらものを考える。こ れは天井，屋根を一体と考えたときの熱貫流抵抗であ つて, 室内外の温度差 $1^{\circ} \mathrm{C}$ のき天井 $1 \mathrm{~m}^{2}$ 当たり の流出熱量の逆数である。天井, 屋根からの熱損失 $H_{c}$ は, 天井, 屋根の総合熱貫流抵抗を $R_{t}$ その面積 を $A_{c}$ としたとき

$$
H_{c}=\frac{A_{c}}{R t}\left(t_{i}-t_{0}\right)(\mathrm{kcal} / \mathrm{hr})
$$

となる。ここで注意しなければならないのは， $t_{i}$ は基 準室温である。天井の温度は, 冬季には室内気温に上 下分布が生ずるため $t_{i} よ り$ 高くなるので，天井，屋根 からの熱損失量は，(3) 式で求められた值の $20 \%$ 増 しとする。

(c) 床面からの熱損怣 床面からの熱損失は土間 床のときと, 揚げ床の場合とで異なるが，いずれにし ても熱損失量を $H_{f}$ とすると 


$$
H_{f}=K\left(t_{i}-t_{0}\right)(\mathrm{kcal} / \mathrm{hr})
$$

と書くことができる。 $K$ は揚げ床の場合には床面 積 $A_{f}$ に比例し, 土閒床のときは建物の周囲の長さ に比例する。なお (4) 式における $t_{i}$ は基準室温であ るから，床面付近の温度が $t_{i}$ より低くなるので，実 際にはこの式で計算した值の $20 \%$ 減にするのが適当 である。

(2) 換気熱損失 換気による熱損失 $H_{a}$ は次式 によつて与えられる。

$$
H_{a}=q Q\left(t_{i}-t_{0}\right)(\mathrm{kcal} / \mathrm{hr})
$$

$$
\text { ここに }
$$

$$
Q: \text { 換気量 }\left(\mathrm{m}^{3} / \mathrm{hr}\right)
$$

$q$ : 空気 $1 \mathrm{~m}^{3}$ の熱容量で空気の定圧比熱に空気 の比重を乗じたものになり，約 $0.3 \mathrm{kcal} / \mathrm{m}^{3}$ ${ }^{\circ} \mathrm{C}$ である。

ただし $Q$ の值は一定のものではなく, 室内外の温 度差, 外気風速, 建物の腺間の大きさなどによつて異 なる。したがつて建物の陌閒がわかつており，また外 気風速が測られていても，Qは $\left(t_{i}-t_{0}\right)$ の関数であ る。一般には $Q$ として設計換気量を用い, 換気口を
調節するなどの方法によつて，一定の決められた換気 量が保持されているものとする。

（3）建物からの全熱損失量 定常状態においては 室内に供給される熱量 $H$ と, 熱損失の合計が等しく なるはずであるから，

$$
H=\left(\frac{A_{w}}{R_{w}}+\frac{A_{c}}{R_{t}} \times 1.2+K \times 0.8+q Q\right)\left(t_{i}-t_{0}\right)
$$

となり (1) 式と比較すれば

$$
C=\frac{A_{w}}{R_{w}}+\frac{A_{c}}{R_{t}} \times 1.2+K \times 0.8+q Q
$$

が得られる。え考える建物について $R_{w}, R_{t}$, $A_{w}, A_{c}, K, Q$ を計算して $C$ を求めておけば， $t_{i}$ と $t_{0}$ が与えられているときは，そのために必要な暖房 負荷 $H$ 㤎求められる。

II. 3. 2 一般の住宅の所要熱量

標準的な住宅についての熱損失の概算值を表 5 およ び図 9 に示す。表 6 は, 住宅の各部位の熱貫流抵抗の 標準值として推奖されているものである。
和風木造住宅（1階）

\section{表 5 (a) 建物 からの熱損失} 熱貫流による熱損失

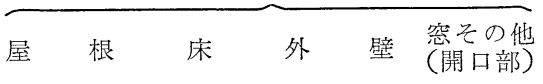

$\begin{array}{llllll}\text { 面 積 比 } & (A) & 1.00 & 1.00 & 1.00 & 0.50 \\ \text { 熱 貫 流抵抗 } \\ \left(\mathrm{m}^{2} \mathrm{hr} \mathrm{deg} / \mathrm{kcal}\right)\end{array}$

（床面積 $1 \mathrm{~m}^{2}$ 当たりの值） 換気による熱損失

2.50

( $\left.\mathrm{kcal} / \mathrm{m}^{2} \mathrm{hr} \mathrm{deg}\right)$

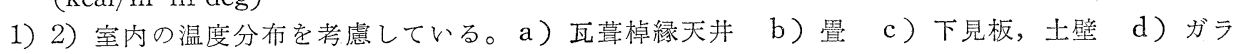

\begin{tabular}{|c|c|c|c|c|c|c|c|c|c|}
\hline \multirow{2}{*}{\multicolumn{4}{|c|}{$\begin{array}{l}\text { 面 積 比 } \quad(A) \\
\text { 熱貫流抵抗 }\left(R_{w}\right)\left(\mathrm{m}^{2} \mathrm{hr} \mathrm{deg} / \mathrm{kcal}\right)\end{array}$}} & 1.00 & 1.00 & 0.45 & 0.25 & & \\
\hline & & & & 0.6 & 1.4 & 0.4 & 0.22 & 建物 の気 積 & 2.50 \\
\hline \multirow[t]{2}{*}{ 室内外温度差比 } & \multirow[t]{2}{*}{$(\Delta \theta)$} & \multirow{2}{*}{$\begin{array}{l}\text { 中 } \\
\text { 最 } \\
\text { 最 }\end{array}$} & \multirow{2}{*}{$\begin{array}{l}\text { 階 } \\
\text { 階 } \\
\text { 階 }\end{array}$} & \multirow{2}{*}{$\begin{array}{l}0 \\
1.2 \\
0\end{array}$} & \multirow{2}{*}{$\begin{array}{l}0 \\
0 \\
\left.0.6^{b}\right)\end{array}$} & \multirow{2}{*}{$\begin{array}{l}1.0 \\
1.0 \\
1.0\end{array}$} & \multirow{2}{*}{$\begin{array}{l}1.0 \\
1.0 \\
1.0\end{array}$} & 換 気 回 数 & 2 回 $/ \mathrm{hr}$ \\
\hline & & & & & & & & 温度 差 比 & 1.0 \\
\hline 流 熱 量 & {$\left[\frac{A \Delta \theta}{R_{w}}\right]$} & $\left\{\begin{array}{l}\text { 中 } \\
\text { 最 } \\
\text { 最 }\end{array}\right.$ & $\begin{array}{l}\text { 層 } \\
\text { 層 } \\
\text { 層 }\end{array}$ & $\begin{array}{l}0 \\
2.0 \\
0\end{array}$ & $\begin{array}{l}0 \\
0 \\
0.44\end{array}$ & $\begin{array}{l}1.10 \\
1.10 \\
0.10\end{array}$ & $\begin{array}{l}1.10 \\
1.10 \\
1.10\end{array}$ & 損失熱量比 & 1.50 \\
\hline
\end{tabular}
ス戸と障子（縁側の場合はもつと小さな抵抗值をとるべきであるう）

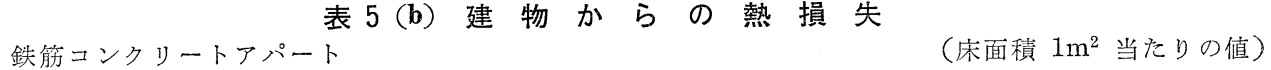 \\ 熱貫流による熱損失

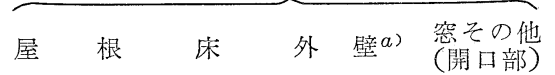 \\ 換気による熱損失} ( $\mathrm{kcal} / \mathrm{m}^{2} \mathrm{hr} \mathrm{deg}$ )

a）階段室も含む。隣家との壁は含まない。b）床下は換気口が小さいものとして計算する。 
(単位 $\mathrm{kcal} / \mathrm{hr}$ )

表 5 (c) 住宅 の 損失 熱量

（温度差 $10 \mathrm{deg}$ 床面積 $40 \mathrm{~m}^{2}$ )

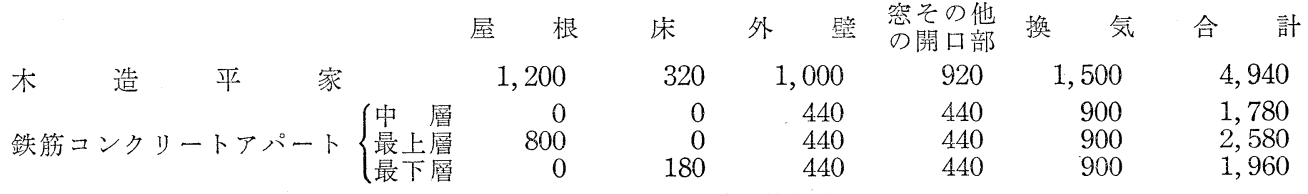

（注）プレハブ建築の部位別性能標準について プレハブ建築協会

日本建築学会設計計画委員会資料（勝田高司提出）による

表 6 地域別推奨熱貫流抵抗*

昼夜間使用する場合

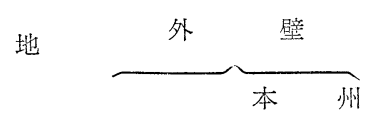

域

甲

乙 $\quad 0.83$

丙 1.00

丁

1.25

0.53

0.63

0.83

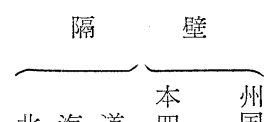

北海道置 国

$0.40 \quad 0.36$

0.43

0.38

0.50

0.40

0.59

0.43

昼間のみ使用する場合

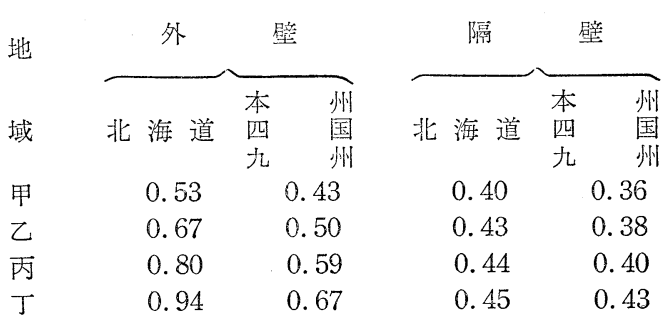

（注）熱貫流抵抗算出基䃈条件

\section{I 北 海 道}

1）地域別区分

$$
\begin{aligned}
& \text { 地 域 } 1 \text { 月, } 2 \text { 月の毎日最低気温の月平均值 } \\
& \text { 甲 } \\
& \text { 乙 } \\
& \text { 丙 } \\
& \begin{aligned}
& >-11^{\circ} \mathrm{C} \\
-11 & \sim-15 \\
-15 & \sim-20 \\
-20 & >
\end{aligned}
\end{aligned}
$$

2）設計用条件

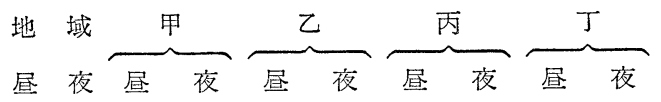

戸 $\left\{\right.$ 気温 ${ }^{\circ} \mathrm{C}-2-11-7-15-12-20-17-25$

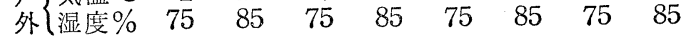

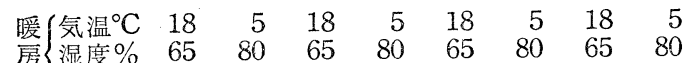
$\begin{array}{llllllll}\text { 室露天 }{ }^{\circ} \mathrm{C} 11.2 & 1.7 & 11.2 & 1.7 & 11.2 & 1.7 & 11.2 & 1.7\end{array}$

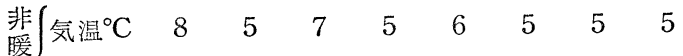

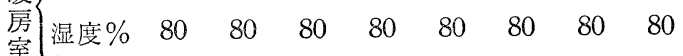

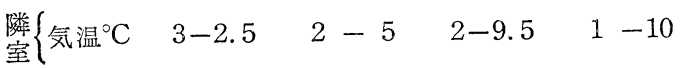

(単位 $\mathrm{m}^{2} \mathrm{hrdeg} / \mathrm{kcal}$ )

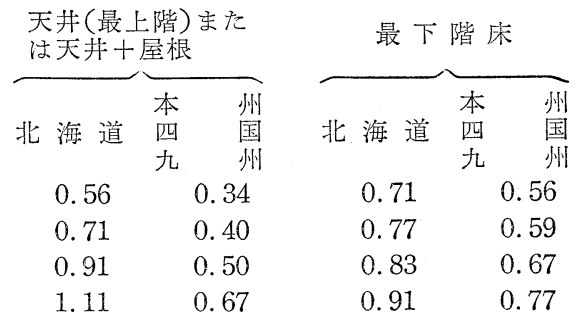

天井(最上階)また は天并十屋根

北海道呬 㖄

最下階床

$\begin{array}{llll}0.42 & 0.34 & 0.71 & 0.36 \\ 0.53 & 0.38 & 0.77 & 0.59 \\ 0.63 & 0.45 & 0.83 & 0.67 \\ 0.74 & 0.52 & 0.91 & 0.77\end{array}$

3）設計目禋

（）内壁面に結露しないこと

(口) 内壁表面温度 $13^{\circ} \mathrm{C}$ 以上

4) 設計用諸値

戸外風速 $5.0 \mathrm{~m} / \mathrm{sec}$

室内壁面 $\alpha . i=7.5$

天井下面 $\alpha_{. i}=9.5$

床 面 $\quad \alpha . i=6.0 \quad\left(\mathrm{kcal} / \mathrm{m}_{2} \mathrm{hr} \mathrm{deg}\right)$

上下温度勾配 天井面 $21^{\circ} \mathrm{C}$, 床面 $17^{\circ} \mathrm{C}$

床下気温(床面附近温度 $\left(17^{\circ} \mathrm{C}\right)+$ 外気温) $/ 2-3^{\circ} \mathrm{C}$

II 本州, 四国, 九州

1）地域別区分

地 域 1 月, 2 月の毎日最低気温の月平均值

甲

乙

$>-5{ }^{\circ} \mathrm{C}$

丙

$-5 \sim-7.5$

两

$-7.5 \sim-10$

丁

$-10>$ 
2）設計用条件

\begin{tabular}{|c|c|c|c|c|c|c|c|c|}
\hline 地 域 & & 电 & & 乙 & & 丙 & ] & $\Gamma$ \\
\hline 夜 & 昼 & 夜 & 昼 & 夜 & 昼 & 夜 & 昼 & 夜 \\
\hline $\begin{array}{l}\text { 気温 }{ }^{\circ} \mathrm{C} \\
\text { 显度 }\end{array}$ & $\begin{array}{r}2.0 \\
70\end{array}$ & $\begin{array}{r}-5.0 \\
85\end{array}$ & $\begin{array}{r}0 \\
70\end{array}$ & $\begin{array}{r}-7.5 \\
85\end{array}$ & $\begin{array}{r}-3.0 \\
70\end{array}$ & $\begin{array}{r}-10.0 \\
85\end{array}$ & $\begin{array}{r}7.0- \\
70\end{array}$ & $\begin{array}{r}-1.50 \\
85\end{array}$ \\
\hline $\begin{array}{l}\text { 温 }{ }^{\circ} \mathrm{C} \\
\text { 点\% } \\
\text { 点 }^{\circ} \mathrm{C}\end{array}$ & $\begin{array}{r}18 \\
65 \\
11.5\end{array}$ & $\begin{array}{r}5 \\
80 \\
1.7\end{array}$ & $\begin{array}{r}18 \\
65 \\
11.5\end{array}$ & $\begin{array}{r}5 \\
80 \\
1.7\end{array}$ & $\begin{array}{r}18 \\
65 \\
11.5\end{array}$ & $\begin{array}{r}5 \\
80 \\
1.7\end{array}$ & $\begin{array}{r}18 \\
65 \\
11.5\end{array}$ & $\begin{array}{r}5 \\
80 \\
1.7\end{array}$ \\
\hline $\begin{array}{l}{ }^{\text {気温 }}{ }^{\circ} \mathrm{C} \\
\text { 湿度 }\end{array}$ & 8 & 5 & 7 & 5 & 6 & 5 & 5 & \\
\hline 温 & 2 & -2 & 1 & -5 & -2 & -7.5 & -5 & -10 \\
\hline
\end{tabular}

3）設計目標

北海道に同じ

4) 設計用諸值

戸外風速 $3.0 \mathrm{~m} / \mathrm{sec}$

室内側熱伝達率 北海道と同じ

上下湿度勾配
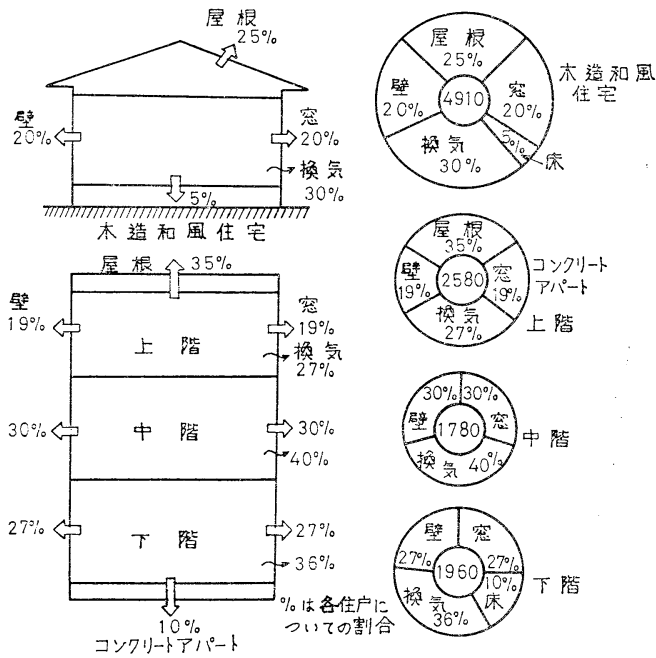

図 9

II. 4. 住宅暖房の現状

住宅おいて用いられる暖房には非常に多くの形式が あるが，ある地方で多く用いられる形式は当然その地 方の外界の条件や，燃料の供給条件などに左右され る。さらにまたその地方の慣習あるいは伝統も大きな 影響を与えている。しかし, 暖房形式は暖房器具の進 歩や経済的, 社会的変化にともなつて次第に変化して いる。

ここでは現在使われている住宅の暖房形式の列挙を 省略し, 地域的にわけてみた時の現状をごく簡単に説 明する。

北海道では，冬の寒さがきびしく，またその期間が
長いために，東北地方に比較して暖房方式としては進 んでおり，石炭ストーブ，薪ストーブなどの煙突の付 いた形式の器具がもつぱら用いられ放射熱を含めて， 室全体を暖房することが行なわれてきた。通常これら のストーブは炊事用熱源として併用される。最近は取 技いの簡単な点から石油ストーブが普及しつつある。 特に北海道の場合は，容量の点と，煙突付きストーブ になれていることもあつて，石油ストーブでも煙突の 付いたものが多く用いられる。暖房時閒は起床時から 就寝時まで連続しているのが通常でありその気温は床 上 $1.3 \mathrm{~m}$ 近くで $23^{\circ} \mathrm{C}$ 程度の場合が多い。また従来は 一室のみを採暖室として暖房している例が多かつたが 最近の住宅がコンパクトな平面を持ち，気密構造にな

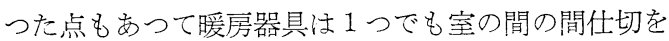
開放して家全体を暖房し，あるい活さらに補助的に煙 突のない小型の石油ストーブを用いるという暖房の仕 响いつつある。

東北，北陸などの地方は寒さのきびしい地方である が，現状では依然としてこたつ類が多く用いられてい る。近時石油ストーブ，ガスストーブが次第に普及 し，特に都市部においてその傾向がいちじるしい。し かしこれら地方で用いられる石油ストーブは煙突のな いものが多いのが現状である。

関東以南の比較的おだやかな地方では, 電気こた つ，石油ストーブ，ガスストーブが多く用いられてい る。寒さがあまりきびしくないので, 煙突付きの容量 の大きなストーブはあまり使われていない。暖房の時 間は，特に寒い期間を除いては間歇的に暖房されるの が通常で, 特に日射量が比較的多い地方では昼間は暖 房空止める場合が多い。暖房をしている場合の室内の 温度注床上 $1.3 \mathrm{~m}$ で, 大略 $20 \sim 23^{\circ} \mathrm{C}$ 程度であるが, 間歇暖房であるため昼間の平均温度は却つて北海道に 比較して低く保たれている。

\section{III. 暖房用燃料之暖屏装置}

III. 1. 暖房用燃料の使用実態

III. 1. 1. 家庭用燃料の使用量のうち暖房用の使 用量が占める割合

おのおのの種類の然料について家庭用（暖ちゆら 房，風呂用など）の然料の供給量の実態はわかつてい る $(3.2 \sim 3.5$ 参照) が, そのらち暖椖用にどの程度 使用されたかといら統計はない。そこで消費者側の統 計として,「総理府, 家計調查総合報告書 (昭和39年)」 を用いて暖房用の然料使用量を推定しようとする。

同報告書の一世帯当たりの月別の然料購大量から冬 期 (11 3 月), 夏期 ( $5 \sim 9$ 月) の購入量を合計す 
るとすべての燃料について冬期の方が多いが，その比 は燃料の種類によつて著しく異なる。そこで暖房用以 外の燃料消費量の冬と夏の比を 1.15 として暖房用燃 料の消費量を算出した。この数值は家庭用 LPG（プ ロパン）の冬と夏の消費量の比を参考にして定めたも のである。

おのおのの然料について家庭用燃料消費量のうち暖 房に使用されたと推定されるものの割合を求めると表 7 のようになる。この值を用いて一世帯当たりの暖房 用の使用熱量を求めると表 8 亿示すようになる。

\section{表 7 各燃料別の家庭用燃料使用量中 暖房に使用されるものの割合}

\begin{tabular}{|c|c|c|c|}
\hline \multirow{2}{*}{\multicolumn{2}{|c|}{ 燃料の種類 }} & \multicolumn{2}{|c|}{ 暖房用使用割 } \\
\hline & & 全 & 人口 5 万以 \\
\hline パ & ע & 0.011 & 0.0 \\
\hline & 油 & 0.640 & .6 \\
\hline 几炭・豆 & 炭 & 0.332 & 0.32 \\
\hline & 炭 & 0.200 & 0.2 \\
\hline & 崖 & 0.442 & 0.3 \\
\hline & き & 0.175 & 0.1 \\
\hline 市 ガ & x & 0.035 & 0. \\
\hline
\end{tabular}

\section{表 8 一世帯当たりの暖房使用熱量}

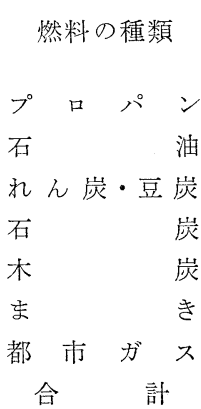

熱量 換 算率

$125 \mathrm{kcal} /$ 円 $450 \mathrm{kcal} / \mathrm{円}$

$5,400 \mathrm{kcal} / \mathrm{kg}$ $6,000 \mathrm{kcal} / \mathrm{kg}$ $7,000 \mathrm{kcal} / \mathrm{kg}$ $300 \mathrm{kcal} / \mathrm{円}$ $172 \mathrm{kcal} /$ 円
暖房使用熱量

全国人口 5 万以上の都市

$2.8 \times 10^{3} \mathrm{kcal} /$ 年
334 "
115 "
295 "
85
57 " "
28 "
917 ”

注この表は数多くの世帯についての平均であるからすべての燃料が含まれて いるが，実際には 1 つの世带ではこのうち 1 種または数種の燃料を用いて 暖房を行なっている。

参考としてポータブル石油ストーブで 6 畳一室を暖 房している例（東京都内）では年閒約 $3 \times 10^{6} \mathrm{kcal} の$ 熱量を消費している。

表 8 の計算では暖房に用いられた電熱を無視してい るが，それを考慮しても昭和 39 年度の全国平均（農家 を除く)の一世帯当たり暖房使用熱量は一室の暖房に 必要な熱量には達していないと考えられる。すなわち 暖身の段階のものがまだかなり多いことを示してい る。

III. 1. 2. 暖房用使用熱量の推移

昭和34年以降の家庭用熱エネルギーの需要の推移は 図10に示すようになる。この中で灯油，プロパンの増 加，木炭，薪の減少が著しいが，灯油の使用量の増加 はほとんど暖房用の需要によるものと思われる。一方 木炭，薪は暖，ちゅう房両用であるがちゆら房用の減 少分はプロパンの増加でまかなわれている。したがつ て木炭から灯油へと暖房用燃料が転換した部分はそれ ほど大きくない。一方都市ガスや電熱の使用量の増加 の多くは暖房用と考えられるので総体としての暖房用 熱量の増加は灯油使用量の増加より大きいものも考え られる。

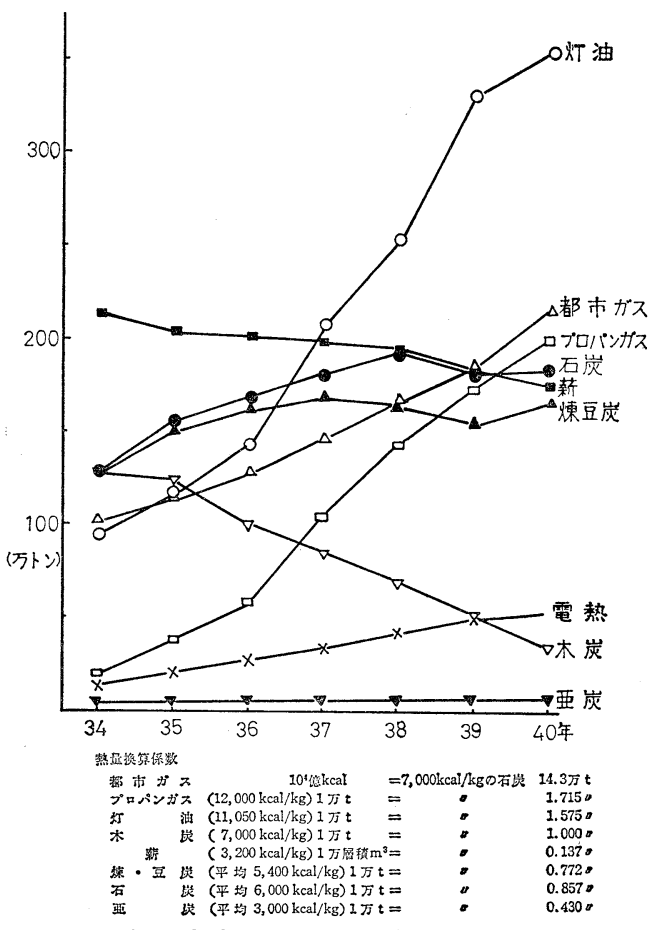

図10 家庭用熱エネルギーの需要推移 $(7,000 \mathrm{kcal} / \mathrm{kg}$ 石炭換算 $)$ 
暖房用のみの需要の実態は統計にあらわれていない ので，略算ではあるが前項の燃料別の家庭用消費のう ちの暖房に用いたものの割合を利用し，燃料別に暖房 用の使用熱量を求めて，その和をとつて全般の傾向を みよらとした。

図11にわが国の年間の使用燃料の全体の熱量に対す る家庭用の使用熱量，および暖房用使用熱量の割合を 示す。家庭用燃料の全熱量に対する割合は最近やや減 少しているが，その中で暖房用熱量はわが国の全熱量 使用量にほぼ比例し，いくらか上昇する傾向もみられ る。推論のたて方を考慮にいれると, 家庭暖房に使用 される熱量はわが国の全消費熱量より大きな割合で増 加していると判断してよいであろう。

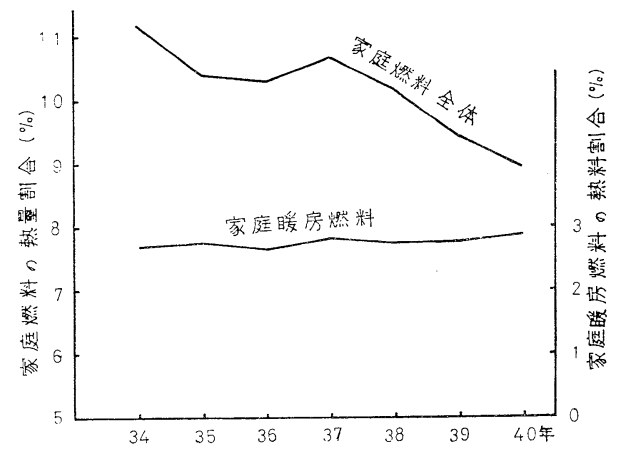

図11 わが国の使用燃料全熱量に対する家庭用
燃料および家庭用暖房燃料の熱量の割合

III. 2. 木炭および成型無煙然料とそれによる暖房 装置

III. 2. 1. 然 料

家庭暖房用燃料として使用されている無煙燃料とし ては木炭のほかに, たどん, 孔あき煉炭 (以下煉炭と いう）と無煙豆炭（以下豆炭といら）がある。

(1) 木 炭

木炭には黒炭と白炭とがあるが，両者はその製法が 若干異なるのでその相違は性質に現われている。すな わち後者は前者に比べ質はやや堅く, 着火温度も前者 の $350^{\circ} \mathrm{C}$ 前後に対し, 後者は $460^{\circ} \mathrm{C}$ 前後である。な おおのおのの分析例は表 9 に示すとおりである。

\section{表 9 木炭の工業分析}

\begin{tabular}{|c|c|c|c|c|c|}
\hline & $\begin{array}{l}\text { 水 }(\%) \\
(\%)\end{array}$ & $\begin{array}{c}\text { 灰 分 } \\
(\%)\end{array}$ & $\begin{array}{c}\text { 揮発分 } \\
(\%)\end{array}$ & $\begin{array}{c}\text { 固定崖萦 } \\
(\%)\end{array}$ & $\begin{array}{l}\text { 総発熱量 } \\
(\mathrm{kcal} / \mathrm{kg})\end{array}$ \\
\hline 晨 & $5 \sim 10$ & $2 \sim 4$ & $5 \sim 25$ & $67 \sim 83$ & $6,840 \sim 7,400$ \\
\hline 炭 & $7 \sim 10$ & $2 \sim 4$ & $\sim 11$ & $76 \sim 84$ & 6,86 \\
\hline
\end{tabular}

(2) たどん

以前は木炭粉をふのり，つのまたで固めたが，現在 では火着きをよくするため，木炭粉に素灰（おがく ず), 樹木の下枝などを野焼きで炭化したものを重量 比でおよそ $20 \%$ と，これに少量のパルプ廃液を混 じ，一般に球形に成型する。原料を充分に粉砕して成 形すれば，“おき”になつても形のくずれることはな い。以上のようにして作られたものの工業分析の一例 を示すと表10のとおりである。

\section{表10 たどんの工業分析}

水分灰分揮発分固定炭素 総発熱量 全イオウ (\%) (\%) (\%) (\%) (kcal/kg) (\%)
$5.7 \quad 37.3 \quad 9.6$
47.4
4,350
0.2

備考 試料汇直径 $7 \mathrm{~cm}, 1$ 個の重量約 $180 \mathrm{~g}$ の球形

(3) 煉炭

無煙炭に硝石灰約 $5 \%$ と粘結剂としてパルプ廃液を 若干加え，表11に示す程度に粉砕したものを煉炭独特 の形に成形，乾燥したものである。買炭は点火がやや 不便なので火着きをよくするため，木炭粉に若干の無 煙炭，酸化剂などを混合したものを図12のように煉炭 の一面に固着した着火煉炭がある。なお煉炭はその使 用目的によつて表12に示す大きさがあり，その組成は およそ表13に示すとおりである。

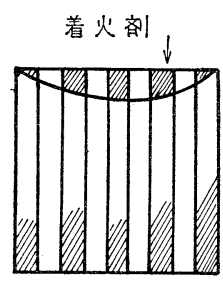

図12 着火煉炭

表11 稒炭原料の粒度の一例
粒 径 $(\mathrm{mm})$
4.7以上
$4.7 \sim 1.2 \quad 1.2 \sim 0.25$
重量比 $(\%)$
5
33
35
粒 径 $(\mathrm{mm})$
重量比 (\%)
$0.25 \sim 0.07$
13
14

\section{表12 煉炭の呼称と大きさ}

\begin{tabular}{|c|c|c|c|}
\hline 称 & ${ }^{\text {直 }}(\mathrm{mm})^{\text {径 }}$ & ${ }_{(\mathrm{mm})}^{\text {高 }}$ & 重 $(\mathrm{g})^{\text {星 }}$ \\
\hline 号煉炭 & 約 94 & 約 95 & 790 \\
\hline 号 煉炭 & $115 \sim 117$ & $110 \sim 120$ & " 1,460 \\
\hline 号煉炭 & 約 120 & 約 110 & " 1,480 \\
\hline 号 煉 炭 & $142 \sim 152$ & $135 \sim 160$ & " 2,920 \\
\hline 号 煉 & $174 \sim 180$ & $150 \sim 170$ & 4,770 \\
\hline 号 & $\sim 220$ & $160 \sim 185$ & " 6,360 \\
\hline
\end{tabular}


表13 搷岸の工業分析

水分灰分揮発分固定素総発熱量 全イオウ

(\%) (\%) (\%) (\%) (kcal/kg) (\%)

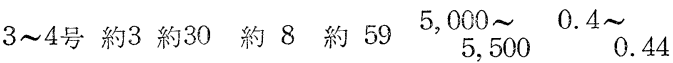

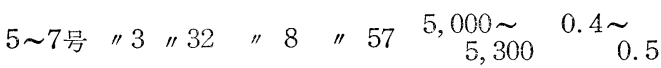

(4) 豆炭

豆炭は原料として無煙炭 85 87\%，素灰（前揭） 8 $\sim 10 \%$. 消石灰約 $5 \%$ に粘結剤（デキストリンなど） と若干の水を加え, 表14亿示す程度に粉砕し, 輪転機 で成型，150 160 $\mathrm{C}$ で乾燥して製品とする。1 個の 重量は $50 \mathrm{~g}$ 前後であるが表15にその工業分析例を示 す。

\section{表14 豆崖原料の粒度の一例}

粒 径 $(\mathrm{mm})$ 0.6以上 $0.6 \sim 0.25 \quad 0.25 \sim 0.15$

重量比 (\%) 2924

粒 径 $(\mathrm{mm})$ 0.15 0.07 0.07以下

重量比 $(\%) \quad 13 \quad 21$

\section{表15 豆炭の工業分析例}

水分灰分揮発分固孷素 総発熱量 全イオウ (\%) (\%) (\%) (\%) (kcal/kg) (\%)

$3 \sim 418 \sim 2011 \sim 1463 \sim 66 \quad 6,100 \sim 6,400 \quad 0.6 \sim 0.8$

III. 2. 2. 暖房装置

(1) 暖房装置の種類

前述の燃料を使用する暖房装置には（a）火鉢, こたつ，あんかのような暖身用と（b) ストーブに わけることができる。燃料と暖房装圈の組合せはつぎ のとおりになる。

$$
\text { 火鉢こたつあんかストーブ }
$$
木炭
$\mathrm{O}$
たどん
O
煉炭 $\bigcirc$
0
○
豆炭 $\mathrm{O}$
○

火鉢で煉炭を燃焼する場合には図13に示すよらな陶 製の火鉢に上つけ壊炭こんろを入れて使用する。別に 図14に示すような金属ケースに入れて“レンヂ”と称 する場合がある。

こたつは最近では後述のような腰掛式が多く使用さ れている。あんかは木炭，たどんを然料とするものは 全く影をひそめ，図15に示すように金属のケースに石 綿または岩綿を詰めた豆炭あんかが使用されている。 ストーブには図16に示すような煉炭ストーブがある
が，ありり普疋していない。

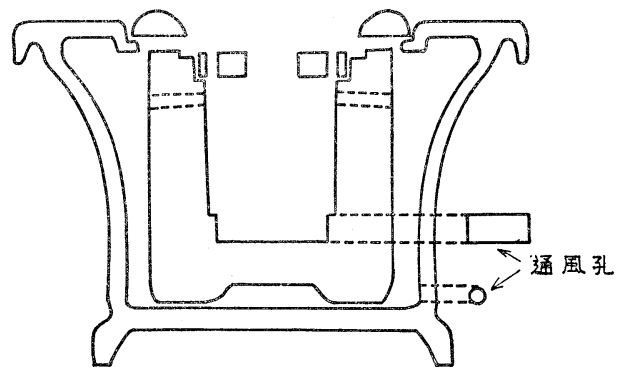

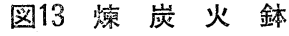

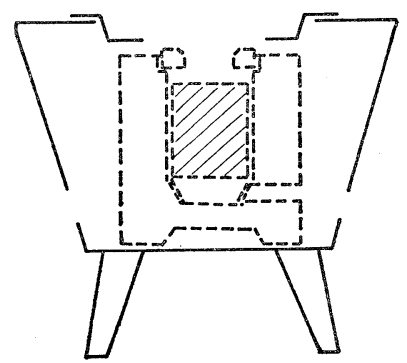

図14 煉崖レンヂ

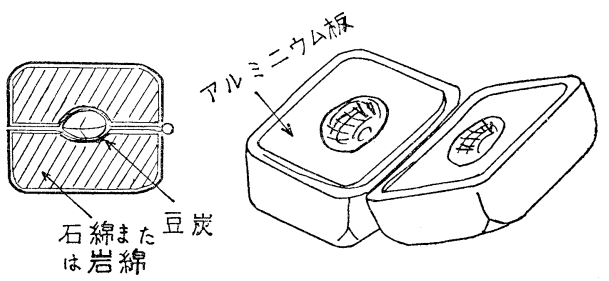

図15豆炭あんか

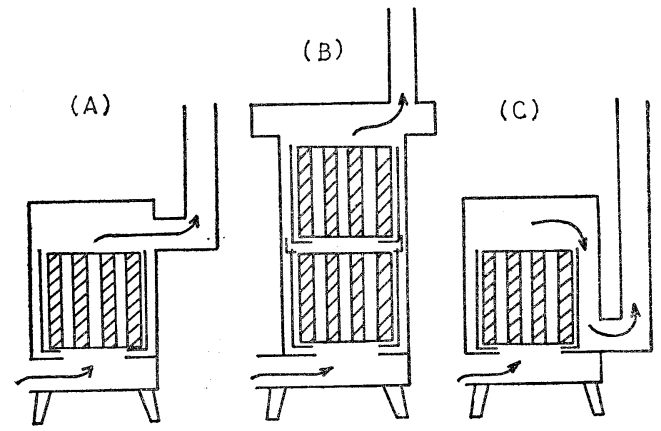

図16 煉炭ストーブ 
(2) 燃料消費量

おのおのの暖房装置における燃料の消費量はその使 用法によつて著るしい相違があるがその若干例をつぎ に示す。

(a) 火鉢の例 火鉢の口径を変えて木炭の燃焼量 を比較したものを表16に示す。実験は $100 \mathrm{~g}$ の赤熱木 炭の上へ $400 \mathrm{~g}$ の黒炭をのせた場合である。

\section{表16 火錝における木炭の燃焼量}

$\begin{array}{ccc}\begin{array}{c}\text { 火錥の口径 } \\ (\mathrm{cm})\end{array} & \begin{array}{c}\text { 木炭の燃焼量 } \\ (\mathrm{g} / \mathrm{hr})\end{array} & \begin{array}{c}\text { 放 熱 量** } \\ (\mathrm{kcal} / \mathrm{hr})\end{array} \\ 12 & 210 & 1,400 \\ 24 & 250 & 1.670 \\ 31 & 370 & 2,460\end{array}$

*木炭の真発熱量 $6,670 \mathrm{~kg}$ とした。

（b）火鉢に大れる上づけ煉炭こんろに高 4 号煉炭 （重量 $1,490 \mathrm{~g}$ ) を入れ, 図17のように $600 \mathrm{~W}$ の電 熱器に90分間通電して煉炭に点火させ，燃焼面が煉炭 の下面まで到達した時

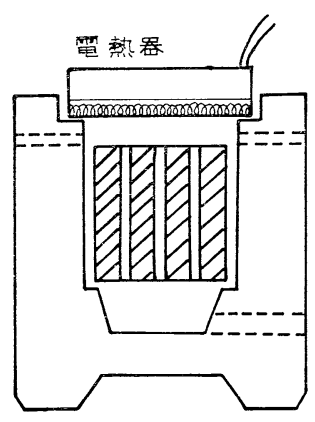

図17 上つけ煉炭コンロ
（通電をはじめてから 120 分）方燃焼減量 を測定した例を示すと 図18のとおりである。 なお煉炭こんろの下 部通風孔は全開とし た。また燃焼面が煉炭 の下面に到達するまで は水分の蒸発が多いの で然焼量は測定しなか つた。

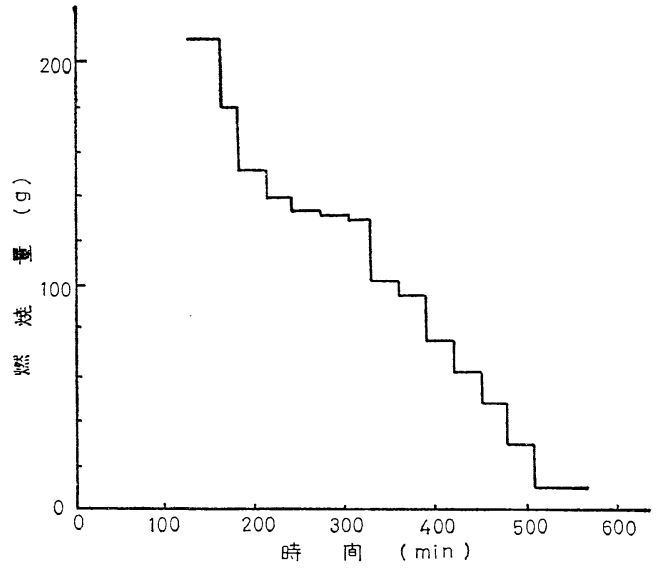

図18棟炭の燃焼速度

（c）こたつ，あんかの例 図19のようなこたつで 室温 $7 \sim 11^{\circ} \mathrm{C}$ とき, 電熱器を用いてこたつ内部を 60 $70^{\circ} \mathrm{C}$ に保つた場合の所要熱量は表 17 とおりである。

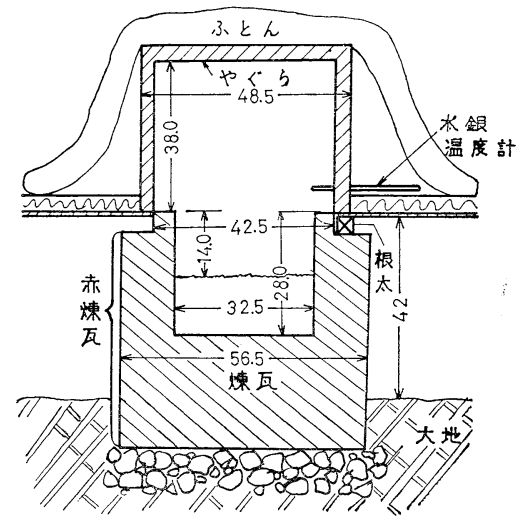

図19こたつの構造
表 17 こたつの 所要 熱 量

実験人員㐫部温度供給電力熱量換算

(人) $\quad\left({ }^{\circ} \mathrm{C}\right)$ (Watt) (kcal)

人員 1 人当たり

\begin{tabular}{|c|c|c|c|c|c|}
\hline & (人) & \multicolumn{2}{|c|}{$\left({ }^{\circ} \mathrm{C}\right)$} & (Watt) & (kcal) \\
\hline $\mathrm{a}$ & 0 & & 70 & 100 & 86 \\
\hline b & 2 & 約 & 58 & 250 & 215 \\
\hline c & 4 & $" \prime$ & 58 & 300 & 260 \\
\hline d & 0 & $" \prime$ & 96 & 300 & 260 \\
\hline
\end{tabular}

所要熱量 木炭換算

86

(kcal/hr) (g/hr)

備考 木炭の真発熱量を $6.670 \mathrm{kcal} / \mathrm{kg}$ とした
約 13

$\frac{215-86}{2} \fallingdotseq 65 \quad$ "I 10

$\frac{260-86}{4} \doteqdot 40 \quad$ " 6

- $\quad$ " 34 
すなわちこのこたつではその内部を $60 \sim 70^{\circ} \mathrm{C}$ に維持 するだけで木炭は $13 \mathrm{~g} / \mathrm{hr}$ の燃燒を必要とし，人1 人ごとに $6 \sim 10 \mathrm{~g} / \mathrm{hr}$ の木炭を必要とすることになる が，同じょうな条件で 3 人の人員を暖める場合の木炭 所要量は $12 \mathrm{~g} / \mathrm{hr} /$ 人 である。ただし，これは気候の 温和な東京での例であって寒地における所要熱量は全 く別のものとなること法実験 d からも想像できる。 なお近年腰掛式のこたつが普及しているが図20はその 一例である。

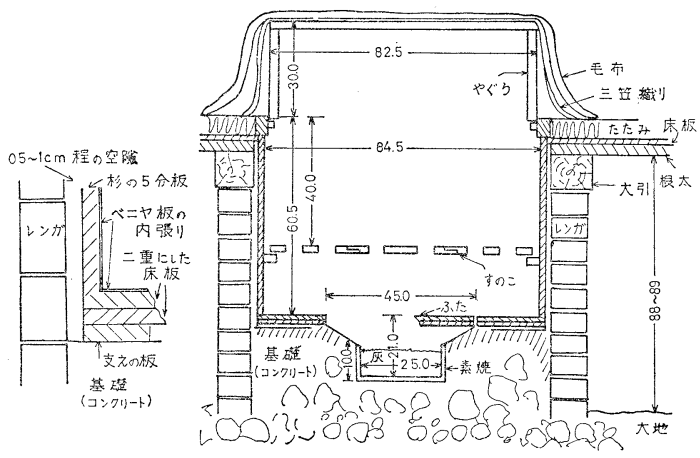

図20 腰掛式こたつ

またこたつに煉炭を燃焼することを考えた場合の煉 炭の然燒持続時間は 20 30 時間であるが，これより 1 時間当たりの燃焼量その他を計算すれば表18亿示す ようになる。

\section{表18こたつにおける熳炭の燃燒量}

1 個 燃焼持 重 量 続時間

燃焼量 放熱量* 電熱推算

(g) $(\mathrm{hr}) \quad(\mathrm{g} / \mathrm{hr})(\mathrm{kcal} / \mathrm{hr}) \quad(\mathrm{W})$

$\begin{array}{llllll}3 \text { 号煉炭 } & 790 & 20 & 40 & 208 & 242\end{array}$

4 号煉炭 1,480 24 30 49 62 254 322 295 375

* 煉炭の低発熱量を $5,190 \mathrm{kcal} / \mathrm{kg}$ とする。

図15のような亜炭あんかでは 1 個約 $50 \mathrm{~g}$ の亜炭の 燃焼継続時間は 15 20 時間であるから，豆炭 1 個の 炭素分を $30 \mathrm{~g}$ とし，炭素の総発熱量を $7,940 \mathrm{kcal} / \mathrm{kg}$ とすれば，1時間当たりの燃燒量その他は表19に示す とおりになる。また，これまでと同じにして煉炭スト 一ブにおいて煉炭が平均に然焼するものと仮定して, 1 時間当たりの燃焼量その他を計算すれば表20のとお りになる。ただし煉炭ストーブ 本体の熱効率を $60 \%$ とし，来た 4 号谏炭拉よび 6 号煉炭の低発熱量はそれ ぞれ $5,190 \mathrm{kcal} / \mathrm{kg} ， 5,050 \mathrm{kcal} / \mathrm{kg}$ とする。

\section{表19 あんかにおける豆炭の燃焼}

\begin{tabular}{|c|c|c|c|}
\hline $\begin{array}{l}\text { 燃焼継続 } \\
\text { 時 } \\
(\mathrm{hr}){ }^{\text {間 }}\end{array}$ & $\begin{array}{c}\text { 燃 焼 量 } \\
\text { (g/hr) }\end{array}$ & $\begin{array}{l}\text { 放 熱 量 } \\
\text { (kcal/hr) }\end{array}$ & $\begin{array}{c}\text { 電熱換算 } \\
(W)\end{array}$ \\
\hline 15 & 2.0 & 16 & 18 \\
\hline 20 & 1.5 & 12 & 14 \\
\hline
\end{tabular}

\section{表20 煉炭ストーブにおける煉炭の燃焼}

使用炭煉炭重量燃焼継燃焼量 放熱量 電熱換算 (g) $\quad(\mathrm{hr})(\mathrm{g} / \mathrm{hr})(\mathrm{kcal} / \mathrm{hr}) \quad(\mathrm{kW})$

\begin{tabular}{|c|c|c|c|c|c|}
\hline 4 号 & 1,480 & 6 & 247 & 770 & 0.9 \\
\hline 6 号 & 4,770 & 10 & 477 & 1,450 & 1.69 \\
\hline
\end{tabular}

III. 3. 家庭用石炭およびコークスとそれによる暖 房装置

III. 3. 1. ストーブ用石炭およびコークスの消費 動向

ストーブ用としての実数把握は困難であり表 21 ，表 22により推定する。

\section{表21暖ちう房炭および家庭用炭動向}

(単位 $1,000 t$ )

40 年度 41 年度 $\quad \begin{aligned} & 42 \text { 年度 } \\ & 4 \text { (推定) (推定) }\end{aligned}$

全 $($ 暖ち5房炭 $4,925 \quad 4,076 \quad 3,732 \quad 3,404$

国 (内)家庭用炭 $3,240 \quad 2,515$

北 $($ 暖ちう房岸 $3,100 \quad 2,917 \quad 2,699 \quad 2,477$

道 $\{$ (内) 家庭用炭 $2,396 \quad 2,261$

東 $($ 暖ちら房炭 $313 \quad 267 \quad 240 \quad 230$

北 $\{$ (内)家庭用炭 $157 \quad 121$

（注）指定統計（40４1年）および協会推定（42４3 年)により薪炭業者报いを含む。 $6,500 \mathrm{kcal} / \mathrm{kg}$ 換算

\section{言22 暖らう房用コークス荷应実續}

(単位 $\mathrm{t}$ )

39 年度 40 年度 41 年度

全 国 134,555 125,052 124,037

(註) コークス統計月報による

わが国暖家庭用崖け急速な減少を示しつつあること が表21より察知できる。家庭用炭のらら，風吕用が約 30\%（北海道の場合）を占めているので，大約 150 160万 $\mathrm{t}$ を本年度の家庭用炭とみなしらる。また北海 道以外の消費はきわめて㪕微である。今後この傾向は 助長されよう。 
暖ちゆら房用コークスの数量は年間 12 万 $\mathrm{t}$ 程度の ものであり，夏季の月間引取が約 $2,000 \mathrm{t} /$ 月 となつ ているので約 10万t/年 足らずの量が暖房関係と推定 でき，家庭ストーブ用コークスとしてはおそらく 6〜 7 万 $\mathrm{t} /$ 年 程度のものであろら。

41年度下期から北海道暖房炭サービスセンターが発 足し，42年度の総予算は 5,500 万円であり，これに道 庁, 国家の補助 800 万円を加えて, 暖房器具の開発, 無煙化の研究のほか, 暖房炭消費の発展策が講じられ ている。その運用いかんによつては, 前記表と異なつ た動向を示すこともあり得よう。

III. 3. 2. 石炭ストーブの諸型式とその性能

家庭用の一般ストーブの種類はきわめて多いが，こ れを一次空気の流入方向と, 燃料の燃焼方向により分 類すると，図21の 4 型式に要約できる。

(a) 上向通風，上向燃焼

（b）上向通風，下向燃焼

(c) 横向通風, 傾斜燃焼

（d）下向通風, 傾斜然焼

（a）は投込式であり，代表的なものにダルマスト ーブがある。(b) はいわゆるルンペンストーブ（上 つきストーブ）である。

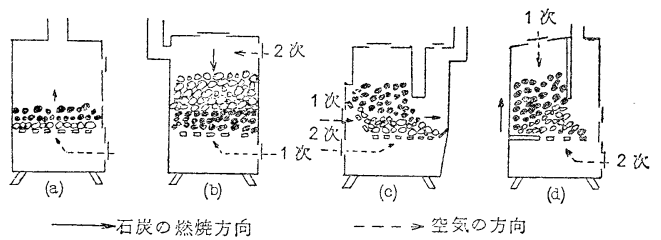

図21一般ストーブの代表的形式

いわゆる貯炭式といわれるものの大部分が (c) 型 式であり，(d) 型式については微粘結炭用としてフ ランスなどで採用されているが，わが国でも最近開発 されている。

上記のごとく原則的なものは簡単であるが，2次空
気のとり方，貯炭室と燃焼室の分離の仕方，放熱面の デザインなどにより，性能は多岐にわかれる。

近年図22のごとき，下込給炭機による燃焼熱な導入 外気に熱交換して室内に放出せしめる。大型自働スト ーブが，外国から導入され可なりな消費実績を得てい る。

表23にこれらストーブの型式別にわが国で，実用に 供せられているものの諸性能を比較した。

もらろんこれらの規模燸要に応じて，大きくも小 さくもなしうるものであることは，いうまでもない。

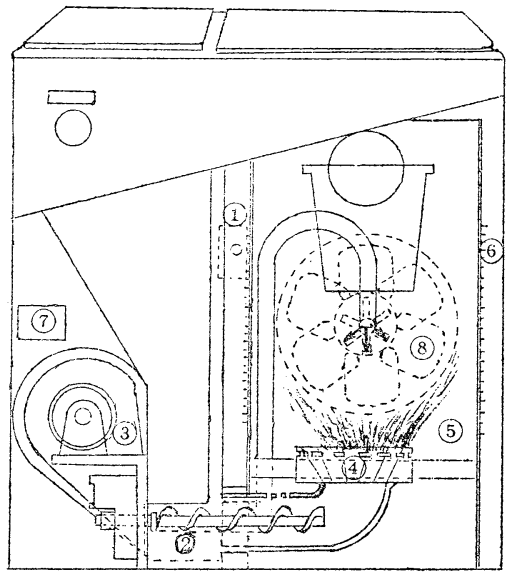

図22下込給炭式ストーブ例

1. サーモスタット（温風温度調節）

2. 給炭スクリニ

3. ブロワー

4. 羽口

5. 燃焼室

6. 熱交換室

7. 自動運転用リレーボックス

8. 温風用ファン

貯炭量および然焼持続時間は下込式を除いた一般ス トーブで貯炭式が必ずしも優れているわけではない。 したがつて貯炭式をここでは流下式と命名する。貯炭 量に関しては，平均して上つき方式方優位にある。

\section{表 23 ストーブ型式別諸性能の概算}

\begin{tabular}{|c|c|c|c|c|c|}
\hline & $\begin{array}{c}\text { 貯 } \\
\mathrm{kg} / \text { 崖 }\end{array}$ & $\begin{array}{c}\text { 燃燒速度 } \\
\mathrm{kg} / \mathrm{hr}\end{array}$ & $\begin{array}{c}\text { 然燒 時 間 } \\
\mathrm{hr} / \text { 回 }\end{array}$ & $\begin{array}{c}\text { 最大放熱 量 } \\
\mathrm{kcal} / \mathrm{hr}\end{array}$ & $\begin{array}{c}\text { 䁔房可能床面積 } \\
\mathrm{m}^{2 *}\end{array}$ \\
\hline 设达方式 & $2.3 \sim 13$ & $1.5 \sim 4$ & $1 \sim 3.5$ & $7,000 \sim 18,000$ & $29 \sim 75$ \\
\hline 上っき方式 & $6 \sim 12$ & $1 \sim 2$ & $6 \sim 10$ & $5,000 \sim 10,000$ & $20 \sim 40$ \\
\hline 下㐬 方式 & $2.5 \sim 23$ & $1 \sim 2$ & $1.5 \sim 11$ & $5,000 \sim 10,000$ & $20 \sim 40$ \\
\hline ニ一クス用 & $2 \sim 7$ & $0.8 \sim 1.5$ & $2.5 \sim 5$ & $4,000 \sim 8,000$ & $17 \sim 33$ \\
\hline 込 式 & $35 \sim 100$ & $1.5 \sim 4.5$ & $20 \sim 30$ & $8,000 \sim 27,500$ & $33 \sim 115$ \\
\hline
\end{tabular}


投込方式は，手数をはぶくため石炭の保有力（1回 の給炭量〉を高くとるが，火床面積も広いから持続時 間は短い。ピーク放熱量は高いが放熱量の変化も激し く, 給炭直後のばい煙発生は歴青炭でに防禦困難であ る。また給炭回数の多い欠点もある。

上つきストーブでは，下降燃燒期と上向燃焼期にわ かれる。正常燃焼では, 着火速度は約 $0.4 \mathrm{~cm} / \mathrm{min}$ と みなしうるので, $40 \mathrm{~cm}$ の石炭層では, 100 分で下底 に達し，上昇燃焼期はこの 3 4 倍となる。したがつ て 400分 500分 で1クールが完了する。このような 燃焼では上つきの孔明煉炭と同じょうに，ばい煙の発 生は最初の短時間に限定され，大部分を無煙とするこ とができる。ただし，暖房を連続せしめるためにはス トーブをペアで使わなければならぬ。

流下式ストーブのらちで図21の（c）に属するもの はその種類きわめて多く, 規模も大小さまざまであ る。デザインについても最も研究されている分野であ る。しかし，ばい煙消去については，図でわかるよう に (d) より劣るが, 2 次燃焼室, 隔壁, 2 次空気な どの工夫により若干の効果を挙げているにすぎない。

(d) 型式は上つき方式を逆にしたような燃燒方式 をとる。1 次空気は貯炭筒外部の 2 重構造により, 筒 を空冷したものが使用されることが多く, 粘り炭の夕 ナつりをある程度防禦する。

コークス用としては石炭焚のすべての方式を適用で きるが，通例使用されているのは流下方式である。一 般にコークス燃焼は一相燃燒であるから石炭然焼より 単純であり，燃燒室も小さくてよい。

ストーブ暖房の優劣は下記により定まる。

(i) 有害ガスを室内に放出しないこと。

（ii）室内空気の温度を平等に上げ易いこと。

（iii）調節が簡易で，負荷応答性の高いこと。

（iv）燃料供給，残渣排除の容易なこと。

（v）ばい煙の少ないこと。

（vi）火災危険の少ないこと。

(vii) 多目的(炊事兼用, 湿度調節)に使えること。

(viii) 燃料の経済性

(ix）ストーブの経済性

（x）ストーブの装飾性

下込式を除いた石炭コークス用一般ストーブについ ては, ( i ), (vi), (vii), (ix)などは満足すべき実情にあ る。(ii)については，輻射によるよりも対流が優れて いるが，下込方式は強制対流方式である。最近強制対 流を上つきストーブに取り入れたものが現われてい る。(iii)は炭質通気力との関連多く, ivは貯炭維持時 間家屋様式に関係が深い。（v）については後述する。 （viii）は産炭地においては流体燃料に優つている。(x) は(ix) と逆相関となるが,さらに研究を要する問題で ある。

III. 3. 3. 燃料, 燃燒方法およびばい煙防止

ばい煙防止には燃料の選択と燃焼方法の選択の $2 つ$ の方向がある。

固形ばい煙は灰塵と炭質ばい煙（タールミストを含 む）に大別できる。灰塺発生泣炭化度の低い石炭ほ ぞ, サイズの小さいものほど, 灰分の高いものほど大 である。炭質ばい煙 (炭煙) 発生性は, 揮発分 $1 \%$ 㐫 たりの燃燒熱と燃料 $1 \%$ 中の揮発分の発熱量の相乗 積と正相関する。これは一定の設備, 燃焼量のもとに おいて, 種々の固体燃料を燃焼する場合の炭煙発生性 の相対的位置を知るに便利である1)。

$$
\text { 炭煙指数 }=\frac{\left(H_{h}-80.8 \times F C\right)^{2}}{1000 V_{m}}
$$

ここで

$$
\begin{aligned}
& H_{h}: \text { 燃料高位発熱量 } \mathrm{kcal} / \mathrm{kg} \\
& F C: \text { 固定炭素 } \% \\
& V_{m}: \text { 揮 発 分 } \%
\end{aligned}
$$

この式により,茨城炭, 天北炭, チクラ炭 $V_{m} 20 \%$ 前後 のコーライトなどは近似の炭煙発生性向を示し, 灰分 の少ない弱粘結炭は炭煙を発生し易いことがわかる。

下込燃焼のごとく, 強制通風下では, 炭煙は減少す るが灰塵量は増加する。

燃焼技術の要ていは, 被燃燒物を着火温度以上に保 持すること, 空気と燃燒体との接触を常に維持するこ と，適当な然燒空間をあたえることの 3 点につきる。 これは炭煙防止の要ていでもある。

着火温度は環境により若干の相異はあるが, 瀝青炭 の $325 \sim 400^{\circ} \mathrm{C}$ に対し, 無煙炭は $440 \sim 500^{\circ} \mathrm{C}$, , ב 一クスは $500^{\circ} \mathrm{C} \sim 600^{\circ} \mathrm{C}$ と高いことと, 瀝青炭の火格 子上に生ずるオキに比べて, 空気との反応速度が遅い ため, 上記着火温度以上の維持に因難を伴、易いが, 一度燃焼が定常化すれば，気相および固相の 2 相燃焼 形態をとる石炭より管理は容易である。

一方, 石炭の分解ガスおよび表面燃焼の産物である $\mathrm{CO}$ などは，1相のみを取り扱うガスバーナ燃焼のご とく, 空気との混合を定型化することが困難で, 1 次 空気の残部のみに依存するが, 別に供給される 2 次空 気の補助も加えて, ガス相燃燒が達成される。すなわ ち空気の配分管理により, 表面燃焼, ガス相燃燒両者 の調和をとることが必要となる。 
ばい煙の発生は主として, 着火時に限定される。こ れは火種に接する石炭面は着火温度に達していても, 脱出した乾留ガスは火種から遠ざかり, 着火温度以下 に冷却されることと，煙突に通気力が生じていないか ら混合が充分でなく、いわゆる燃焼の 2 要素において 欠けているためである。これを克服するためには，充 分な火種 (オキ) を乾留ガスの通路におくことが必要 である。オイルまたはタール系の着火剂はかえつて初 期ばい煙を助長するから使用しない方がよい。火種が ない時は, 木片を多量に使う。木片は炭煙指数が低 く, 着火容易で, オキも充分に残すからである。

ストーブに抒いては, 灰落し以外治層, 炭層の手 入を必要とするようで注, それだけで落第である。火 勢の調節は簡単な通気調節にのみ依存できるものであ らねばならない。

流下式ストーブ特に（c）型に弱粘結炭を使用する と，たなつり，ブローホールなどを作つて空気と燃焼 物間に不均衡を生じ，手入れを必要とすることがおき 易い。これ泣炭煙発生の原因となる。したがって, 通 例の流下式ストーブには冴物炭 (固有水分約 $3 \%$ 以上 の非粘結炭) が使用される。

(d) 型の流下式ストーブでは, 炭層が空気により 冷却されることと, 火焰の未燃炭層内一の上昇性向を 抑制できる点が（c）型と異なり，それだけ粘結性炭 にも適合性を持つている。

上つき方式は (d) 型の流下機構を取り除いたもの であるから，それだけ簡略化され，しかも流下に伴う トラブルの心配が皆無であるから, 通例の粘結炭を讶 物炭と同䇐に取り扱うことができる。ただし，讶物は 2 次空気割合を多くとり, 粘り物ではほとんど 1 次空 気依存せしめることが必要となる。

自然通気のストーブはドラフトが $2 \sim 3 \mathrm{~mm} \mathrm{Aq}$ 以下 で弱く，また，上つきおよび流下式ストーブで厚い炎 層内を通気せしめる機構になつているものは, 石炭サ イズとして, 通気抵抗の少ない中小塊が要求される。 特に空間を充填する粉の混入注有害となる。流下式粉 炭ストーブの場合には, 粘らない石炭を使用すること と, 1 次空気と粉炭の接触着火面の拡大策 (例 1 次空 気分散用燒玉装入）を講ずる必要がある。

一般に炭化度が進むほじ然焼速度は遅く，また同一 通気環境ではサイズの小さい核ど然焼速度は早くなる から，同一環境で同一放熱量を実現するには炭化の進 んだものほど小粒とすべきである。すなわち讶物で 30 50mm のストーブに弱粘結炭を使ら場合は, 適 確ではないにしても，20〜 40mm 位が適当となる。
これは混炭使用の場合にも適用されるべきである。 コークス, 無煙炭など反応性の悪いものは石炭に比し 小粒が要求される理由もここにある。

投込式ストーブは, 広範囲の炭質, サイズに使用可 能であるが，ばい煙を防ぐには，炭煙指数の少ない燃 料によるほか対策はない。

下込式ストーブには，自動操作をさまたげないた め, 固有水分約 $3 \%$ 以上の灰耐火度高く, 微粉の少な 、粉炭が適当である。

（参考）家庭用暖房器具調査（北海道深川東高校の 家庭アンケート)

1. ストーブ所有台数

$\begin{array}{cccrcc} & 1 \text { 台 } & 2 & \text { 台 } & 3 \text { 台 } & \text { 計 } \\ \text { 31年 } & 71.8 & 25.0 & 2.5 & 99.3 \% \\ \text { 41年 } & 53.0 & 30.0 & 15.0 & 98.0 \%\end{array}$

2. ストーブの種類

流下式 上つき式 投込式 粉炭 石炭計

$\begin{array}{rrrrrr}31 \text { 年 } & 35.1 & 0.7 & 15.1 & 11.6 & 62.5 \% \\ 41 \text { 年 } & 44.5 & 7.7 & 5.4 & 4.8 & 62.4 \%\end{array}$

\begin{tabular}{|c|c|c|c|c|}
\hline & 油 & 新 & ガ & 計 \\
\hline & 0 & 23.1 & 0.2 & $85.8 \%$ \\
\hline & 18.4 & 12.6 & 2.7 & $6.1 \%$ \\
\hline
\end{tabular}

3. ストーブ使用の部屋の面積

6 畳 8 盢 10 盢 10 盢以上 計

$\begin{array}{llllll}31 \text { 年 } & 27.8 & 31.3 & 3.4 & 2.3 & 64.8 \% \\ 41 \text { 年 } & 39.1 & 33.4 & 9.9 & 8.4 & 90.8 \%\end{array}$

III. 4. 家庭燃料用の石油製品とそれによる暖房装 置

III. 4. 1. 家庭然料としての石油製品の適性 家庭然料として燃料に要求される条件としてはつぎ のごとく考えられる。

1. 経済的であり, 発熱量当たりの単価が安いこ と。

2. 取扱上安全であること。(技術者でない一般の 主婦が取扱つても引火爆発などの危険がないこ と)

3. 取扱上清潔, 衛生的であり, 毒性がないこと。

4. 供給が安定し, 流通機構が整備されているこ と。

などがあげられるが，現在家庭で容易に入手可能な石 油製品 (燃料油) についてその一般性状と家庭然料と しての適性を比較してみると(表 $24^{2)}$ 参照)。L P ガ ス (III. 5. 参照) 以外法, 特殊な用途を除けば灯油 が最も適していることがわかる。（欧米では軽油もか 


\begin{tabular}{|c|c|c|c|c|c|c|}
\hline & ti & 品 & & 名 & & JIS 規 格 \\
\hline & 口 & パ & ン & ガ & ス & $\begin{array}{l}\text { 液化石油ガス } 3 \text { 号 } \\
\text { (JIS K 2240-1967) }\end{array}$ \\
\hline & & & シ & & ン & 工業ガソリン 1 号 \\
\hline
\end{tabular}

(JIS K 2201-1958)

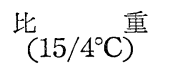

$0.51 \sim 0.56$

$0.668 \sim 0.764$

$0.778 \sim 0.800$

$(0.72 \sim 0.76)^{*}$

$0.724 \sim 0.769$

(0.753)

自動車ガソリン 2 号 (JIS K 2202-1965)

$0.712 \sim 0.753$

(0.732)
（自動車ガソリン）自動車ガソリン 1 号

白灯油灯油 1 号

茶灯灯油 2 号

軽

A 重 油重油 1 種 $(1 \sim 2$ 号)
$0.779 \sim 0.811$

(0.791)

$0.781 \sim 0.842$

(0.794)

$0.821 \sim 0.841$

(0.823)

$162 \sim 216$
$(184)$

$0.821 \sim 0.892$ (0.855)
表 24 石 油製品 の性 状

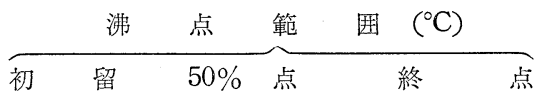

95\%:-15 - 1

[95\%: +2以下]

$\begin{array}{lcl}32 \sim 46 & 68 \sim 93 & 117 \sim 150 \\ \text { [30以上] } & \text { [100以下] } & \text { [150以下] }\end{array}$

$152 \sim 157$

166 169

[180以下]

$192 \sim 2003$

[205以下]

$(30 \sim 42) * \quad(80 \sim 130) *$

$(160 \sim 210) *$
$78 \sim 114.5$

(106.0)

$184 \sim 216$

(199.0)

$30 \sim 41$

(36.2)

$80 \sim 121$

(94.0)

[125以下]

$153 \sim 178$

$172 \sim 208$

(193.5)

$\begin{array}{rr}153 \sim 184 & 170 \sim 216 \\ (164.6) & (191.3)\end{array}$

$235 \sim 283$

(266)

$170 \sim 270 * \quad 260 \sim 310^{*}$
$172 \sim 210$

(189.8)

[97\%:-20.5以下]

$220 \sim 260$

(241.3)

[95\%:-320以下]

$221 \sim 287$

(246.4)

[95\%:-320以下]

$313 \sim 396$

(343)

[90\%:-350以下]

450 以上*

注〔]内は JIS 規格の限界值, ( ) は調查試料の平均值, * は推定值

なり用いられているが，わが国では軽油引取税の対象 となつているので灯油のが経済的である。)

以下主としてわが国の場合について灯油を中心とし た石油然燒器具, 特に暖房装置についての一般情勢, 実用性能などについての問題点を概説することにす る。(なお一般的な文献を本文末尾に揭げた $\left.{ }^{3) ~ 11)}\right)$ 。

III. 4. 2. 灯油および石油燃燒器具をめぐる一般 情勢

\section{（1）灯油の需給と一般性状の推移}

戦後石油製品の統制撤廃が行なわれた直後の昭和 27 年には灯油の需要は 12 万 $\mathrm{k} l$ にすぎなかつたが，その 後石油コンロの普及により，また昭和32年頃以降は石 油ストーブの普及によつて灯油需要は急激な増加を続 けてきた。(表25 $\left.5^{12}\right)$ ) 灯油と用途としては農発用燃料, 溶剤などもあるが，大半は家庭用然料として用いられ ており，統計上は民生用灯油として扱われている。灯
油は他の石油製品と異なり需要に夏冬の皎差が大き く，石油ストーブの普及が一巡したとみられた昭和 40 年春頃には灯油の夏季需要開拓の必要性が叫ばれたこ ともあつたが13), 需要の実績はその後も大きな伸びを 示している。これは石油暖房器具が家庭内でますます 賞用されるようになつたこと, および昭和40年頃から 大型のポット式石油ストーブが急激に増加し始めたこ と，ならびに石油風呂釜などが普及してきたことによ るものと考えられており, 昭和 46 年度までの石油需給 計画においては46年度に 632 万 $\mathrm{k} l$ の民生用灯油需要 が見込まれている。

各社の製品灯油の性状近年一応安定してきている が, 白灯油の平均性状は引火点約 $50^{\circ} \mathrm{C}, 95 \%$ 留出温 度 $225 \sim 230^{\circ} \mathrm{C}$ ，イオウ分 $0.01 \sim 0.02 \%$ であり，煙 点は 25 29mm, 芳香族含量 は 15 19\% 程度であ る。茶灯油の性状は白灯油と変わらないものもある 


\section{と家庭燃料としての適性}

(性状は一例定示す)

引 火 点

家庭燃料としての適性

適用する然燒装置

(III. 3. 5 のガス然料の項を参照)

本来は洗浄用であつて, 洗浄用のベンジンを燃料と して用いることは危険であるが，むつと沸点範围の せまい（初留 $55 \sim 60^{\circ} \mathrm{C}$ 以上）イオウ分の多いベン ジンは接触燃焼用燃料として適している。

$35 \sim 42$ [30以上]

RVP: $0.43 \sim 0.70$ (0.58)

RPV: $0.48 \sim 0.73$ (0.60)

$42 \sim 61$

(50.6)

[38以上]

$42 \sim 65$

(49.2)

[35以上]

$63 \sim 95$

(78)

[50以上]

$66 \sim 98$

(79.1)

[60以上]
沸点は比較的高く，ベンジンよりは安全であるが， 芳香族を合むので家庭然料としては余り適当でな い。

引火性が強いため取技いに注意を要するが少量を予 熱用 (着火，暖機用) 燃料として用いるのには適す る。本来は洗浄用

本来火花点火機関用であつて引火性艻強く，またほ とんどの場合毒物であるアンチノック剂が添加され ているので家庭然料として使用してはならない。

(喍税額 28.7 円 $/ l$ )

引火点が高い(平均 $50^{\circ} \mathrm{C}$ 前後) ため安全であり, 石油ストーブ(小型) 精製されたものを適正に燃焼させれば煙突なども不石油コンロ 要な場合が多いので家庭用燃料として最適である。 ガソリン，軽油のように課税されないので経済的で ある。

灯油よりもさらに安全ではあるが，日本の場合には 課税 (引取税 $15.0 \mathrm{H} / l$ ) 対象となつているので経 済的でない。

集団住宅などの大型燃焼装置のバーナ一用としては ボイラー用(集中暖房など) 灯油より経済的な場合が多い。
カイロ Catalytic stove 加压式ストーブ予熱用

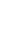


表 26 灯 油の - 般

試験項目 $\quad$ IIS 規格

-1965) 最低最高平均

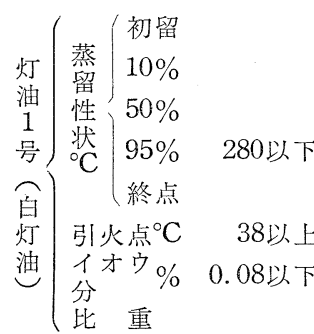

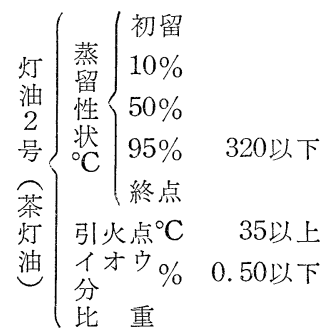

36 年 12 月

\section{2}

162

$180 \quad 167.9$

$194 \quad 180.6$

170

$206 \quad 190.1$

198 207

$251 \quad 228.5$

$278 \quad 241.2$

38

$62 \quad 51.2$

$\begin{array}{lll}0.003 & 0.060 & 0.0291\end{array}$

0.7794

0.8270

0.7993

\begin{abstract}
151
\end{abstract}
161

167

185

221

38

0.003

0.781

$0.25 \quad 0.1186$

$0.845 \quad 0.7996$
38 年 6 月

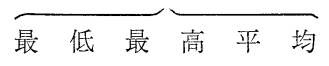

144.5

$186 \quad 163.8$

$194 \quad 177.5$

$205 \quad 192.3$

$245 \quad 226.2$

$260.5 \quad 237.5$

$\begin{array}{ll}62 & 49.7\end{array}$

$\begin{array}{ll}0.07 & 0.027\end{array}$

$\begin{array}{lll}0.780 & 0.815 & 0.7967\end{array}$

0.001
0.780

$188 \quad 163.9$

$198 \quad 179.2$

$239 \quad 196.0$

$266 \quad 231.0$

$281 \quad 249.8$

$\begin{array}{ll}66 & 49.5\end{array}$

40

0.28

0.218
38 年 12 月

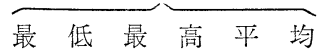

$\begin{array}{lll}152 & 184 & 164.9\end{array}$

$\begin{array}{lll}171 & 193 & 177.5\end{array}$

$\begin{array}{lll}182 & 203.5 & 192.3\end{array}$

$\begin{array}{lll}204 & 243.5 & 224.7\end{array}$

$\begin{array}{lll}219 & 226.5 & 239.8\end{array}$

$\begin{array}{lll}41 & 63 & 49.6\end{array}$

$\begin{array}{lll}0.0009 & 0.056 & 0.0197\end{array}$

$\begin{array}{llll}0.781 & 0.8248 & 0.7914\end{array}$
が，高沸点留分やイオウ分がやや高いものもあつて性 状には比較的バラッキがあり，イオウ分が平均 $0.2 \%$ 程度であることが白灯油と異なる点である。（表 $26^{14)}$ 参照)

（2）石油燃焼器具の生産と普及台数

石油燃焼器具の生産は石油コンロから始まつたが,

\section{表27 石油燃焼器具の生産台数（万台）}

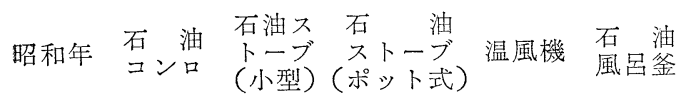

$\begin{array}{cccccc}33 & 100^{*} & 10 & - & - & - \\ 34 & 210 & 20 & - & - & - \\ 35 & 180 & 45 & - & - & 1^{*} \\ 36 & 110 & 135 & 0.5^{*} & - & 1^{*} \\ 37 & 132.4 & 343.8 & 1^{*} & - & 2^{*} \\ 38 & 54.7 & 431.7 & 5^{*} & - & 3^{*} \\ 39 & 28.4 & 330.8 & 10 & - & 5^{*} \\ 40 & 27.5 & 245.0 & 11.5 & 1.2 & 10^{*} \\ 41 & 27.5 & 334.9 & 20.3 & 1.1 & 12^{*} \\ (42) & (17 *) & \left(380^{*}\right) & \left(40^{*}\right) & & \end{array}$

* 印：日本然焼器具検查協会資料 その他 $\left\{\begin{array}{l}\text { 機械統計月報, 日本ガス石油機器工業会資料 } \\ \text { (燃協誌, 46, No. 481, p. 400, 1967年5月) }\end{array}\right.$
最近では完全に小型, 大型の暖房器具の方へ生産の主 流が移った形である。(表27 8) 9) ) 最近はポット式石 油ストーブの生産の伸びが著しいよらである。普及台 数について正確に推定することは困難であるが，全世 帯の $53.0 \%{ }^{14)}$ 亿普及しているといら推定も行なわれ ている。

\section{（3）灯油と石油燃燒器具をめぐる特殊事情}

(a) 生産と流通の機構について

灯油の流通機構は (L P ガスの場合も類似である が）他の石油製品の場合とはかなり異なつている。す なわち元売会社 $\rightarrow$ 販売業者 (二者, 三者) $\rightarrow$ ツリリン スタンドといら販売系列以外に, 販売業者から薪炭 商, 金物商, 日用雑貨商など, あるい核各種消費者組 合などを通じて扱われ，最終的に各家庭の消費者一届 けられている。

一方燃焼器具の生産者についてみれば, 石油コンロ 全盛時代に多数存在した專業メーカーは次第に陶汰さ れ, また家庭電器メーカーの進出によりかなりの専業 メーカーはその系列下に入り, 専業メーカーは一部を 残すのみとなつた。ポット式などの大型暖房器具につ いてはさらに別種のメーカーの動きも西るようであ る。

これらの生産業者ならびに輸入業者は本来自分が 持つている販売網に製品販売を行ならが，それ以上の 
性 状 の 推 移

39 年 6 月

\begin{tabular}{|c|c|c|}
\hline 最 低 & 高 & 平 \\
\hline 153 & 178 & 165 \\
\hline 163.5 & 189 & 178 \\
\hline 172 & 208 & 193 \\
\hline 193.5 & 247 & 225 \\
\hline 220 & 260 & 241 \\
\hline 42 & 61 & 46 \\
\hline
\end{tabular}

$\begin{array}{lll}0.001 & 0.068 & 0.0188\end{array}$

$0.7787 \quad 0.811 \quad 0.7906$
39 年 12 月

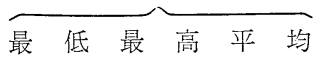

$178 \quad 164.1$

$164 \quad 191.5 \quad 177.3$

171

197

214

40

0.001

0.777

201

252

265

62

0.06

0.815

193.7

227.3

242.2

49.8

0.0199

0.7886
40 年 6 月

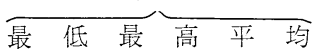

154

177

165.2

177

181.5

211.5

224

45

0.001

0.7830

$186 \quad 164.4$

201

179. 2

212

196.9

169.5

191

221

42

0.04

0.7806

$216 \quad 191.3$

$257 \quad 225.9$

$287 \quad 246.4$

$65 \quad 49.2$

0.30

0.159

0.842

0.7939

184

209.5

229.5

246.5

42

67

0.03

$0.30 \quad 0.1686$

0.778

0.834

0.7928

$0.803 \quad 0.7904$
$265.5 \quad 249.7$

増販は各社閒の自由競争の形で行なわれてきたため， しばしば異常在庫などの混乱を起した。小型石油スト ーブ全盛時代のこの実績にかんがみ，大型石油ストー ブ全盛時代のこの実績にかんがみ，大型暖房器具につ いては暖房器具メーカーと石油会社とが共同の販売サ 一ビス体制を作ろらとする動きがある。

\section{(b) 課税の問題}

ガソリンと灯油, 灯油と軽油は原油から連続的に留 出する留分であつて本来㛜密には限界を設けにくい性 格のものであるが，ガソリンと軽油はともに課税対象 とみているのに灯油のみは課税されていない。灯油が 安価であるのはこの免税措置によるものであり, その 価格はガソリンなど（ナフサなどを含めて）の需給バ ランスと市況に直接閒接に左右されるものであること に留意する必要がある。

一方燃燒器具に関しては, 小型石油ストーブの場合 は生産者の出庫価格が 6,000 円 ( 2 年前までは 5,000 円）以下のものは実用品であるという見地から，また ポット式石油ストーブの場合は $15.000 \mathrm{kcal} / \mathrm{hr}$ 以上 のものは業務用といら見地から物品税 (20\%) が免除 されることになつている。この事実は生産者が器具を 設計する場合に微妙な制約を与えており, 器具の性能 の面にも影響を与えているように考えられる。

$\begin{array}{rrrrr}189 & 178.7 & 167 & 188 & 175.8 \\ 201 & 193.6 & 176 & 214 & 194.8 \\ 239 & 224.3 & 211 & 260 & 230.5 \\ 255 & 238.0 & 220 & 276 & 244.8 \\ 65 & 51.0 & 45 & 56 & 49.9\end{array}$

$\begin{array}{lllll}0.03 & 0.012 & 0.001 & 0.06 & 0.015\end{array}$

$0.7810 \quad 0.8296$

0.7938

$\begin{array}{rrrrrr}155 & 187 & 165.2 & 157 & 179 & 164.2 \\ 164 & 199 & 178.9 & 163 & 214 & 179.1 \\ 173 & 211 & 193.6 & 172 & 239 & 195.0 \\ 195 & 252 & 223.7 & 208 & 276 & 231.5 \\ 209 & 274 & 239.4 & 219 & 290 & 245.1 \\ 41 & 66 & 49.7 & 40 & 70 & 51.1 \\ 0.01 & 0.33 & 0.160 & 0.001 & 0.44 & 0.190 \\ 0.777 & 0.832 & 0.7944 & 0.780 & 0.830 & 0.7950\end{array}$

\section{（4）石油燃焼器具の JIS 規格化の進展}

当初石油コンロが普及するにつれて，火㷋の原因と なるような事故が頻発したため，主として火災に対す る安全性向上の見地から担当官庁と日本燃燒器具検查 協会が中心となつて昭和32年初めて JIS 規格の制定を 行なつた。改正を重ねるごとに安全性を中心とした試 験項目が修正追加されてきたが，この努力は石油スト 一ブや附属機器に関しても行なわれてきた。一時は火 災の原因の首位を占めたことのある石油燃焼器具が最 近のように普及したにもかかわらず比較的安心して使 用できるような技術水準に到達したことについては生 産者の努力もさることながら JIS 規格の果した意義を 高く評価すべきであろう。ポット式石油ストーブに関 するJISもすでに制定されているが，近く石油風吕釜 の JIS も制定される予定である。（表28に JIS 規格の 要点を表示した。)

(5) 石油燃焼器具の形式の推移 ${ }^{9)}$

前述のように現在の石油燃燒器具の主体はすでに普 及している小型石油ストーブおよび今後の伸びが予想 されるポット式石油ストーブであるが，小型石油スト ーブに関する型式の推移を表示すると表29のごとくで あつて，最近ではシン上下式が約 $90 \%$ ，落差式が 約 10\%を占め，シン上下式の内訳注放射型が約 70\%， 対流型が約 $20 \%$ となつている。(表29参照) 
$\begin{array}{ccc} & & \\ \text { 名 } & & \text { 称 } \\ \text { 石油 } & \text { ン }\end{array}$

石油ストーブ

ポット式石油ストーブ

石油燃焼器具用シン

ストーブ用スケルトン

石油燃焼器具用注油ポンプ

石油フロバーナー（シン式）

石油フロバーナー（ポット式）

表 28 石油燃焼器

JIS 番号

種 類, 形 式

JIS S 2016-1965

制定，1957/4

改正, 1960/2

$\left\{\begin{array}{l}\text { 落 差式 } \\ \text { シ 盖下式 } \\ \text { 加 压 式 }\end{array}\right.$

JIS S 2019-1965

制定, 1958/8

改正, 1961/1，1962/8,

$1963 / 5,1965 / 2$

(1967/7 改正予定)

JIS S 2039-1964

制定, 1964/12

JIS S 2038-1965

制定，1965/2

JIS S 2025-1962

制定, 1960/8 改正, 1962/8

JIS S 2028-1966

制定，1962/3

改正，1966/12

JIS S 3017

JIS S $3018\left(\begin{array}{c}1967 / 9 \\ \text { 制定見込 }\end{array}\right)$ $\left\{\begin{array}{l}\text { 落 差 式 } \\ \text { 卡々式 } \\ \text { 加 压 式 }\end{array}\right.$

$\left\{\begin{array}{lll}\text { 対 流 形 } \\ \text { 放 射 形 }\end{array}\right.$

$\left\{\begin{array}{l}\text { 自然通気式 } \\ \text { 強制通気式 }\end{array}\right.$

$\{$ 自然対流形

強制対流形

$\left\{\begin{array}{l}\text { 普通シン 䈪シンンン } \\ \text { 成型シン(平シン } \\ \text { 筒シン) }\end{array}\right.$

$\left\{\begin{array}{l}\text { 扎形 }(1 \sim 5 \text { 号 }), \text { 角形 }(1 \sim 4 \text { 号 }) \\ \text { 两面形 }(1 \sim 2 \text { 号 }), \text { 棒状 }(1 \sim 3 \text { 号 })\end{array}\right.$

$\left\{\begin{array}{l}\text { 金属製， } 18 l \text { カン用 } \\ \end{array}\right.$

\section{表 29 石油燃焼器具 (小型) の型式の推移}

\begin{tabular}{|c|c|c|c|c|c|c|c|c|c|c|c|}
\hline 和 & 型 & 式 別 & $\%$ & \multirow{3}{*}{$\begin{array}{l}\text { 検查台数 } \\
(\times 1,000 \text { 台 })\end{array}$} & \multirow[b]{3}{*}{ 落差式 } & 型 & 式 & 別 & $\%$ & \multirow[b]{3}{*}{ 加圧式 } & \multirow{3}{*}{$\begin{array}{l}\text { 検査台数 } \\
(\times 1,000 \text { 台 })\end{array}$} \\
\hline & & & & & & & ン & 下 & & & \\
\hline & 落差式 & 上下式 & 加圧式 & & & （小計） & $\begin{array}{l}\text { 放射型 } \\
\text { 赤熱式 }\end{array}$ & $\begin{array}{l}\text { 対流型 } \\
\text { 青炎式 }\end{array}$ & $\begin{array}{l}\text { 詨流型 } \\
\text { 白炎式 }\end{array}$ & & \\
\hline 33 & 0 & 94.5 & 5.5 & 216 & - & - & - & - & - & - & \\
\hline 34 & 0 & 94.5 & 5.5 & 1,243 & 0 & 44.4 & 40.0 & 0 & 4.4 & 55.6 & 10 \\
\hline 35 & 0.1 & 89.4 & 10.5 & 1,182 & 11.9 & 21.9 & 16.5 & 3.2 & 2.2 & 66.2 & 370 \\
\hline 36 & 0 & 93.2 & 6.8 & 557 & 40.4 & 47.0 & 25.2 & 9.8 & 12.0 & 12.6 & 62 \\
\hline 37 & 0.2 & 99.7 & 0.2 & 670 & 33.6 & 66.2 & 24.7 & 13.5 & 28.0 & 0.2 & 1,988 \\
\hline 38 & 0 & 98.2 & 1.8 & 273 & 12.0 & 88.0 & 40.7 & 31.6 & 15.7 & 0 & 3,312 \\
\hline 39 & 0 & 99.7 & 0.3 & 1,725 & 5.5 & 94.5 & 52.6 & 28.7 & 13.2 & 0 & 2,506 \\
\hline 40 & 0 & 100.0 & 0 & 237 & 8.1 & 91.9 & 73.2 & 10.4 & 8.3 & 0 & 2,334 \\
\hline 41 & 0 & 100.0 & 0 & 170 & 11.0 & 89.0 & 67.8 & 8.2 & 13.0 & 0 & 3,14 \\
\hline
\end{tabular}


関 係 J I S - 覧 表

試験項目

構造試験（材料，加工法，構造など）, 荷重試験, 漏 レ試験, 而圧試験, 破ビン試験, 落下試験, 塩水試 験，傾斜試験

燃焼試験（熱効率，燃焼ガス中の $\mathrm{CO} / \mathrm{CO}_{2}$, 油温, 器具関係各部一油タンク, ッマミ，木台，側面木壁 一の温度, 燃焼状態)，傾斜燃焼試験，消火試験， 低温試験，注水試験，操作試験，接点繰返試験

構造試験（材料，加工法，構造など）, 塩水試験，落 下試験，破ビン試験，酎圧試験，傾斜試験，転倒試 験, 漏レ試験

燃焼試験(燃焼廃ガス中の $\mathrm{CO} / \mathrm{CO}_{2}$, 油温, 器具関倸 各部一ッマミ，手を子れる部分，油タンク，木台， 側面木壁一の温度, 熱気廃気温度, 白気試験, 燃焼 状態試験）風洞試験，低温試験，傾斜燃焼試験，消 火試験，逆火試験，注水試戨，荷重試験，操作試験 接点繰返試験，絶縁抵抗試験，耐電圧試験

構造試験（材料，加工法，構造など）, 漏レ試験, 塩 水試験

燃燒試煥 (泏温, 器具関係各部一ツマミ, 手を孔れる 部分，木台，側面木壁一の温度，燃焼状態および使 用性能, 熱効率, バイ煙濃度, 消火時間) 油量調節 器試験, 異状流出試験

寸法（币，厚さ，内径）外観

吸上量, 吸上速度

寸法，材料および加工方法，外観 衛撃試験，耐火度

寸法，材料および加工方法，構造 漏レ試鈳, 始動試験, 流量試験, 摩耗試験

以下灯油とこれを燃料とする石油暖房装置の実用性 能などの問題を採り上げるに際し，排気筒 (煙突) を 用いない小型石油ストーブの場合と，排気筒を用いる 大型のポット式石油ストーブの場合とでは器具や燃料 に要求される性能がかなり異なるので両者を大別して 述べることにする。

III. 4. 3. 小型石油ストーブ（排気筒なし）にお ける灯油と燃焼器具の実用性能

(1) 小型石油ストーブの構造16)

いわゆるポータブル型の小型石油ストーブは排気筒 (煙突)を用いることなく然焼排気はそのまま室内に 放出する方式の暖房装置であつて，構造的にみるとつ ぎのように分類できる。

（a）灯油の供給方法による分類

(i) 落差式（落差を利用）

(ii) しん上下式（毛管現象を利用，落差式しん
備 考

1 個の燃焼装置の灯油燃焼量が $80 \sim 500 \mathrm{~g} / \mathrm{hr}$ の 石油コンロについて規定する

1 個の燃焼筒または火口の灯油燃焼量が 80 600 g/hr の石油ストーブについて規定する

最大燃焼量が $3,200 \mathrm{~g} / \mathrm{hr}$ 以下の排気籍を使用文 るポット式石油ストーブについて規定する

緎維で作られた灯油の燃焼器具, すなわちシン上 下式石油コンロ，石油ストーブ，石油フロバーナ 一などに用いるもの部品の互換性，品質および安 全性の向上を目的とする

粘土を主原料として焼成したストーブ用スケレト ンについて規定する

$18 l$ カンから灯油を移すのに用いる金属製注油ポ ンプについて規定

最大然焼量 $1.800 \mathrm{~g} / \mathrm{hr}$ 以下のフロバーナーにつ き規定

最大燃焼量 $3,200 \mathrm{~g} / \mathrm{hr}$ 以下のフロバーナーにつ き規定

上下式併用のものもある)

(iii) 加圧式（空気圧により送油，最近L P ガス の圧力によるものもある。16)

(iv) サイフォン式（サイフォン現象を利用）

(v) ポンプ式（機械力による）

(b) 燃燒方式による分類

(i) 蒸気燃焼式（落差式，しん上下式）

(ii) 噴霧燃焼式 (加压式)

(c) 炎の色による分類

(i ) 青炎燃焼式

(ii) 白炎燃燒式

(d) 暖房方式にょる分類

（i）対流形（対流により室の空気を暖める)

(ii）放射形（スケレトン，放熱ネットなどから の放射の割合が大)

（iii）対流放射併用形（白炎燃焼の場合） 
（e）燃焼筒の構造による分類

（i）単筒式（青炎燃焼, 白炎燃焼の場合）

(ii）複筒式（放熱ネットを使用する場合）

(iii) 単筒, 複筒併用式 (白炎燃焼の場合)

(f) その他

発生熱量に大小の差がある（現状では 1,000 $5,000 \mathrm{kcal} / \mathrm{hr}, 3 \sim 15$ 畳用；2 連式の場合は 9, 500 $\mathrm{kcal} / \mathrm{hr}$ 以下）ほか，湢次的な構造として転倒の 際の火災に対する安全性向上のための装置, ある

いは自動点火装置に具備したものもある。

(2) 小型石油ストーブの特長

他の暖房方式, あるいはポット式に比し, 特長とし ては:一

（a）軽便，移動容易で場所もとらない（配管，煙 突など不要）

（b）経済的に効率よく暖房が可能（燃焼ガスの持 つ熱を室外に出さない方式)

（c）炎の大小の調節が容易（特にしん上下式，加 圧式の場合)

（d）適当に水分を発生する（燃焼した灯油の約 1.2 倍重量の水分を発生する)

(3) 小型石油ストーブの問題点

前記のよらな特長を持つ半面, 小型石油ストーブに は問題点も多い。最近日本然焼器具検查協会が実施し た小型石油ストーブの苦情調查報告（365 件のうち約 8 割がシン上下式であり, 購入時期は37〜39年が 64 \%)によれば：—

\section{イ.くさい，眼にしみる}

(148件)

口. 燃焼状態不良（炎不安定，油煙）

八. 調整器不良(シン上下機構, 油量調節機構)(84件) その他の炎立ち上り不良。油もれ，火が消えないなど の順に苦情があげられている。

その他小型石油ストーブの構造，実用性能などに関

して客観的に問題となるような点をあげると：一

二、火災の伧険，すなわち軽便，移動容易であるた め転倒などによる火災事故が多い。

ホ. 燃燒排ガス, 特に CO による中毒の問題。

へ. 点火より定常燃焼状態に達するまで, また消火 操作より消火に到るまでに若干の時閒を要し, こ の間の不完全燃焼に原因する臭気などの問題があ る。また点火後のシンなどが再調節が行なわれな いと往々炎の過大などによる事故が起りうる。

ト、シンの上などに堆積する炭化物を時々除去し， あるいは劣化，不揃いとなつたシンを調整交換す などの清掃整備操作が必要である。
以上のような問題点に対する対策としては器具（設 計, 整備) および然料の両面から行なら必要がある が，以下大別して要点を述べる。

（a）火災に対する安全性に関する問題

石油ストーブの JIS 規格の制定や改正に際しては器 具の火姼に対する安全性の向上に重点が置かれてお り，たとえば風洞試験や転倒試験 引張転倒值, 油も れ量, 引火時間) などについては数次にわたる改正を 重衫てきた，メーカー側も対転倒自動消火装置や二重 タンク構造などを採用しているところが多い。また灯 油の引火点に関する JIS 規格值も引き上げられてお り，不適正な取扱いが行なわれない限り，安全性の問 題はかなり改善されたものと考えられる。

(b) 燃燒性能と燃焼廃気に関する問題 ${ }^{11) 16)}$

小型石油ストーブの燃燒において燃焼廃ガスが普通 は室外に排出されないといらことは器具や燃料に対し てやや高度の性能を要求することになつているが，問 題となる廃気の内容は点火時, 消火時と定常然燒時と ではやや異なる。

\section{イ. 点火時, 消火時の問題}

これらの非定常燃燒状態においては然焼が若干不安 定となり，酸化中間生成物やすすが燃焼系外に出るの はある程度はやむを得ないことであるが，この状態の 時間をなるべく短かくするように器具の設計および調 整を行なうことが重要であり, 然料としては煙点が高 く，蒸発性状が適当な範囲内にあるような灯油を用い ることが望ましい。

\section{口. 定常燃焼時における問題}

定常燃燒状態において発生するガスとしてまた問題 になるのは亜硫酸ガスおよび一酸化炭素であろう。し かし亜硫酸ガスについては最近の白灯油中のイオウ分 は非常に少なくなつてきている（平均 $0.01 〜 0.02 \%$ ) ので衛生の面から問題になることはあまりないと考え られるが，同時に発生する水蒸気が結露滉象を起すよ らな場合には金属などの腐食の可能性に留意する必要 があろう。

一酸化炭素注不完全燃燒によつて発生する訳である が，頻発した中毒事件などのため大きな問題となつた ため検討の結果 JIS 規格では昭和 41 年 3 月以降 CO/ $\mathrm{CO}_{2}$ として 0.003 以下に定められている。過大ある い将小の炎の状態で注不完全然燒の状態になりやす く，また油タンクが空に近づくにつれて CO の発生 が急に増加する傾向のあることも知られている。また 白炎燃焼 (対流) 形の場合は CO の発生が比較的少 ないといら傾向も認められている。いずれにしても自 
然通風の蒸発燃焼 (シン式の場合) において各種の条 件のできるだけ広い範囲内で, 完全燃焼を維持するこ とについての検討泣まだ余地が残されていると考えら れる。

(C) シンと灯油に関する問題 ${ }^{11}$

現在普及している小型石油ストーブの大部分はシン 上下式であり，前記の苦情調查における処置の実績よ りみて, シンおよびシン上下機構の調整ないし交換に よつて苦情が改善されることが多いことからみても， シンに関する問題はもつと検討する必要があると考え られる。現在のシンは材質的には木綿のほかガラス瀻 維む用いられているが，現行の JIS 注互換性を主目 的としたもので実用性能々関連する試験は今後の問題 であろら。シンは点火, 消火の回数の多い方が炭化物 堆積も多く，いたみやすいといわれるが，現状では消 耗品とみなして頻繁化交換する方が取扱上はむしろ好 ましいとも考えられているよらである。しかし今後耐 火性合成繊維などの新しい材料につき，あるいは織り 方などの加工法についての検討などによつて, シンに 関する問題についてはまだ改善の余地が残されている ようである。

III. 4. 4. ポット式石油ストーブ（排気筒付き） における石油と燃焼器具の実用性能

(1) ポット式石油ストーブの構造 ${ }^{18)}$

前述の小型石油ストーブの場合と同様, 火災に対す る安全性と耐久性を主眼にして1964年 JIS が制定さ れたが，構造的にはつぎのように分類できる。

(a) 空気の供給方式による分類

(i) 自然通気式

（ii）強制通気式（および自然通過と切換式）

(b) 暖房方式による分類

(i) 自然対流形

(ii) 強制対流形

(c) 燃料の供給方式による分類

(i) 落 差式

(ii) ポンプ式その他

(d) 油タンクの位置による分類

(i) 本体に取り付けたもの

(ii) 本体と分離したもの

(e ) 着火方式による分類

(i) 電気着火式

(ii）予熱然料を用いる方式,またはその他の方式 （f） その他

発生熱量に大小の差がある（現状では 6,000 $25,000 \mathrm{kcal} / \mathrm{hr}, 6 \sim 25$ 坪用) ほか, 温度調節装
置により給油, 着火を制御する自動空調方式 (温 風機,またはエアヒーターと呼ばれる)のものも ある。

ポット式石油ストーブは JIS 化されてからまだ日 が浅いため関連する資料は少ないが，昭和40４1年度 の形式検查結果によれば，空気供給方式としては強制 通気式が約 $80 \%$ を占め, 暖房方式としては自然対流 形が多い。最大燃料消費量（表示）は自然通気式では 1.1 1.3 l/hrのものが比較的多く $(40 \%)$, 強制通気 式では $1.6 \sim 1.8 \mathrm{l} / \mathrm{hr}$ および $2.4 \mathrm{l} / \mathrm{hr}$ 前後のものが 多くなつている。熱效率（強制通気式の場合）につい ては，最低熱効率（JIS では 35\% 以上）は 45 64\% のものが多く $(70 \%)$, 最高熱效率 (JIS では 55\%以 上） 65 75\%のものが多く $(75 \%)$ なつている。 (2) ポット式石油ストーブの特長

実用性能に関する実績として北海道消費者協会の調 査結果 ${ }^{19}$ ) (全数のらち 89\% がポット式石油ストーブ であり，購入時期は39年 $40 \% ， 40$ 年 31\%，41 年 26 \%)を紹介すれば，ポット式石油ストーブの特長とし てはつぎのものがあげられている。

イ 小型石油ストーブなどに比較して暖房効果が大 きい（発生熱量大）

口＼cjkstart管理に手間がかからない

八 室内の空気を清淨に保つことができる。

二 静かである。(特に自然通気式の場合)

(3) ポット式石油ストーブの問題点

一方同じ調查結果に現われた問題点としてはつぎの ものがあげられる。

1 燃料費が高くつく（燃料消費量が大きい）

ロファンの音がうるさい（強制通気式の場合）

八 大量の燃料を扱うので火㷋の危険性が心配であ る。

こ煮たきと兼用ができない（最近は兼用型も出て いる)

などであるが，技術的な観点から特に問題となる可能 性のある項目としてはつぎのものが考允られる。

（a）安全性に関する問題

耐久性を含为た安全性に関する構造設計について は, JIS 規格でもかなり留意されているが，特に強制 通気式の場合停電に続く再通電する際の爆発あるいは 異状燃焼の危機がないように，なお検討の余地がある ように考えられる。

（b）適正な通気量，通気方式に関する問題 自然通気式の場合，適正な排気筒の取付けは非常に 重要であるが，強制通気式の場合をも含めて燃焼速度 
に対応するように常に通気量を調整することが是非必 要である。前述のように $15,000 \mathrm{kcal} / \mathrm{hr}$ 以上のポッ ト式ストーブの増加の可能性があるとすれば，このよ らなストーブで治力に比してかなり低い通油量の簯 囲で燃燒させる機会も多くなる訳であり，広い通油量 の範囲で常に適正な通気量の調節が行ない得るような 装置の検討が重要である。バーナーの面からみると最 近の Triple Stage Voporizing Burner ${ }^{7}$ は自然通気 式により広い通油量の範囲で完全燃焼するように検討 されている点が注目される。

（c） ばい煙発生および燃焼室内の炭化物の堆積の 問題

ばい煙の発生については前記の適正な通気量の調整 のほかに油量調節器などによる送油量の調節および適 当な性状の燃料の使用が重要である。海外においては 軽油など比較的重質燃料もポット式の燃料として用い られているが，わが国の場合は主として灯油が用いら れる訳であるから，この限りでは燃料に由来するこれ らの障害はあまりないと考えられる。燃焼室内の炭化 物堆積傾向に関連してポットなどの蒸発面における油 膜の厚さはできるだけ薄くし, 蒸発面に液状で滞留す る時間を少なくするように留意することが重要であ $3^{7220)}$ 。

III. 4. 5. 今後の発展が予想される大型の暖房装置 欧州においてはポット式石油ストーブから, 小型ボ イラーによる全室暖房に, アメリカにおいては全室暖 房から地域暖房に移行しつつあるが，わが国でも住宅 構造の変化, 生活の合理化などとともに徐々に普及し て行く可能性があると考えられる大型石油暖房装置の 一，二の例をあげるとつぎのごとくである。

（1）給湯温水暖房美用の家庭用小型石油ボイラー 前述のように最近家庭用小型石油ボイラーなどの普
及を目的として，器具メーカーと石油会社の協力によ る設計, 施工, 給油, アフターサービスなどの機構が 整備され活動を始めている。

現在のところは給湯を主目的とする場合が多いよう であるが，新しく設計する住宅などの場合には最初か ら温水暖房を設計の中に織り込むことにより,より合 理的な家庭暖房の実施が可能であちう。まだ国産の家 庭用小型石油ボイラーは種類も少なく, バーナーとし てはポット式が多いようであるが，欧米に拉いては各 種型式の家庭暖房用のバーナーが研究されて㧍り ${ }^{7)}$, 今後わが国に扔污るこ種類の暖房装置ないし燃燒器 具に与える影響は少なくないと考えられる。

（2）冷暖房兼用の石油を熱源とする空調装置 ${ }^{21)}$

現在家庭向冷 (暖) 房用の空調装置としては電力に よる圧縮冷凍機方式が主として用いられているが，吸 収式の冷房装置（冷媒として水, 吸収液としてリチウ ムプロマイド）における熱源として灯油などを用いる 方式の空調装置の小型化が行なわれ将来家庭用空調装 置として用いうる可能性がでてきた。

現在のところ最小の装置でも $3.5 \mathrm{RT}$ (RT : 1 冷凍 トン, 約 7 坪冷房能力), $10,600 \mathrm{kcal} / \mathrm{hr}$ (灯油として $2.3 l / h r)$ あつて家庭用としては能力がやや過大に過 ぎる感があるが，今後改良が進めば家庭用として十分 使用できるようになるものと考它らる。

III. 5. 家庭用ガス燃料とそれによる暖房装置

III. 5. 1. 家庭用ガス燃料

(1) 都市ガス

都市ガスは導管で各需要家に供給されているガスで あつて，日本全国で約 740 万戸に普及し，これを供給 するガス事業者は 210 余に達している。ここに主要地 区別都市ガス普及状沉を表30に, 都市ガス販売量の推 移を表31に示す。

\section{表 30 主要地区別都市ガス普及状況}

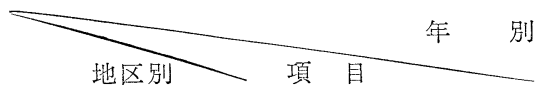

東京・京浜地区 $\left\{\begin{array}{l}\text { 取付メ一夕一数 (A) } \\ \text { 供給区域内総戸数 (B) }\end{array}\right.$ 東邦・名古屋地区 $\left\{\begin{array}{l}\text { 取付メ一夕一数 ( A ) } \\ \text { 供給区域内総戸数 }(\mathrm{B})\end{array}\right.$ 大阪・京阪神地区 $\left\{\begin{array}{l}\text { 取付メ一夕一数 (A) } \\ \text { 供給区域内総戸数 }(\mathrm{B})\end{array}\right.$ 広島・広島地区 $\left\{\begin{array}{l}\text { 取付义一夕一数( }(A) \\ \text { 借給区域内炂戸数(B) }\end{array}\right.$ 西部・福岡地区 $\left\{\begin{array}{l}\text { 取付メ一夕一数(A) } \\ \text { 供給区域内総戸数 }(B)\end{array}\right.$ そ の 他 $\left\{\begin{array}{l}\text { 取付メ一共給区域内総戸数 }(\mathrm{B}) \\ \text { 数 }(\mathrm{A})\end{array}\right.$ 全国 $\left\{\begin{array}{l}\text { 取付メ一夕一数 (A) } \\ \text { 供給区域内総戸数 }(\mathrm{B})\end{array}\right.$ 日本瓦斯協会：ガス事業統計年報
36 年普及率 37 年普及率 38 年普及产

\begin{tabular}{|c|c|c|c|c|c|c|c|}
\hline $\begin{array}{rl}1000 \text { 戸 } & \\
1,808 & 78.9 \\
2,291 & \end{array}$ & $\begin{array}{r}1000 \text { 戸 } \\
2,080 \\
3,647\end{array}$ & 57.0 & $\begin{array}{r}1000 \text { 戸 } \\
2,282 \\
3,884\end{array}$ & 58.8 & $\begin{array}{r}1000 \bar{F} \\
2,495 \\
4,113\end{array}$ & 60.7 & $\begin{array}{r}1000 戸 \\
2,701 \\
4,369\end{array}$ \\
\hline $\begin{array}{l}304 \\
497\end{array}$ & $\begin{array}{l}328 \\
539\end{array}$ & & $\begin{array}{l}354 \\
587\end{array}$ & & & 60.8 & \\
\hline
\end{tabular}

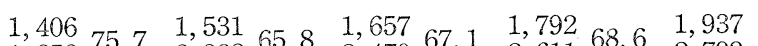

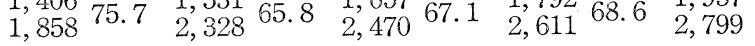
69.2

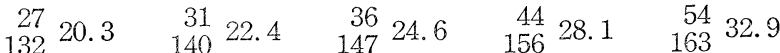

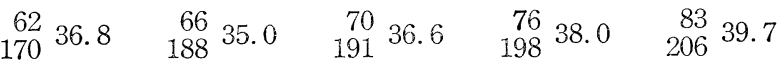

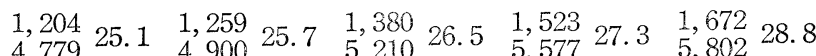

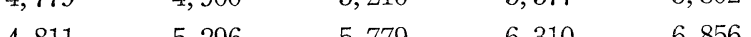

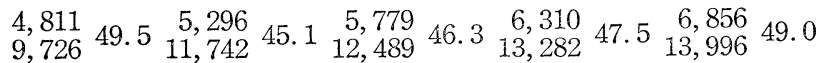


衰 31 都市ガス販売量の推移

年 別

36

37

38

39

40
ガス販売量 (10億kcal)

家庭用その他合計

$9.011 \quad 7,671 \quad 16,682$

10,210

8,360

18,570

11, 766

9,039

20,805

12,917

9,642

22,559

15,182

10,497

25,679

日本瓦斯協会：分ス事業統計年報

\begin{tabular}{|c|c|c|c|}
\hline 家庭用 & 商 業 用 & 工 業 用 & その他 \\
\hline 54.0 & 22.6 & 12.4 & 6.3 \\
\hline 55.1 & 22.4 & 16.1 & 6.4 \\
\hline 56.6 & 22.2 & 14.9 & 6.3 \\
\hline 57.3 & 22.2 & 14.3 & 6.2 \\
\hline 59.1 & 21.5 & 13.1 & 6.3 \\
\hline
\end{tabular}

都市ガスには石炭，原油，ナフサ，L P ガスなどを 原料として製造した発熱量が 3, 600 5.000 kcal/ $\mathrm{Nm}^{3}$ 程度のガスがある。十数年ほど前までの製造方式は， ほとんどコークス炉による石炭ガス，副生するコーク スからのガスに限られていたが，ガス需要の時間的， 季節的変動に詨応しながら製造, 供給を行なう困難に 直面し，これを克服するために種々のガス化方式と原 料を採用してきた。

ガス化方式の種類が多くなると，これらの製造ガス を混合してえられる同一発熱量のガス組成は多岐にわ
たるが，供給されるガスはガス器具に対して良好な然 焼性をもつように注意が払われている。

したがつて現在では原油, ナフサなどの石油原料か ら製造したガスが多くなつて，全体の約 60\%を占 め，そのほか天然ガスやL P ガスを導管供給している 事業者もある。

つまり地域や事業者の規模，原料事情によつて供給 されるがスの組成や発熱量が異なつている。都市分ス

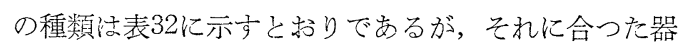
具を選択する必要がある。

\section{表 32 都市 ガスの種 類}

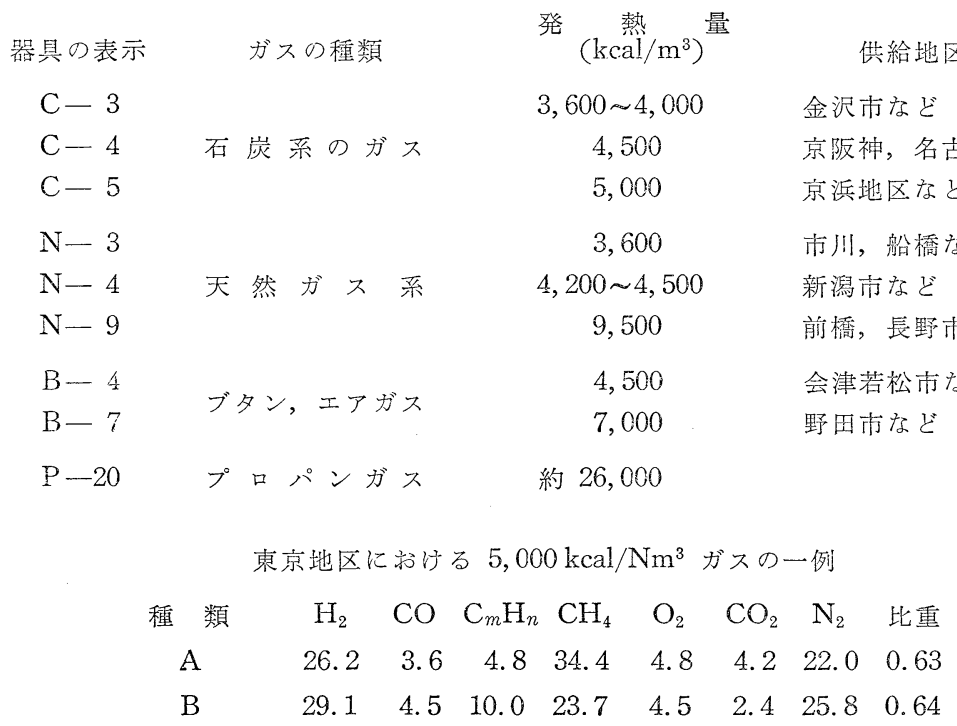

なお一般にガス器具でガスを完全燃焼させるには， 理論空気量の $20 \sim 50 \%$ 多くの過剩空気 が必要であ る。一般に都市がスでは発熱量 $1,000 \mathrm{kcal} / \mathrm{m}^{3}$ につ き, その理論空気量は約 $0.9 \mathrm{~m}^{3}$ と, ほとんど一定で
あることが認められる。たとえば東京地区の 5,000 $\mathrm{kcal} / \mathrm{Nm}^{3}$ の都市ガスの場合, 約 $4.6 \mathrm{~m}^{3}$ である。 (2) 天然ガス

日本は天然ガス資源が貧弱であるが，アメリカ，ソ 
連，カナダなど国内における天然ガスの産出量の多い ところは，ガス田から消費地までの大口径パイプライ ンが非常によく発達している。日本では新潟, 直江津 地区にガス田と消費地を結ぶパイプラインが発達し， 昭和37年には新潟から東京まで $334 \mathrm{~km}$ にいたるパイ プラインが完成した。また水溶性天然ガス田のある千 葉県でも, 営業用, 家庭用に使用するため, 天然妿ス パイプラインが多く敷設されている。

最近の技術革新は低温技術の面でも著しい進歩をと げており，LPガスやエチレンの大量輸送や貯蔵が可 能となり，ついに天然ガスを $-162^{\circ} \mathrm{C}$ 以下で液化し て貯蔵し，タンカー輸送することができるようになつ た。日本ではアラスカ産の L.N. G. 年間 96 万 t 昭和 44 年 3 月から東京瓦斯, 東京電力で輸入を開始す るといら計画がある。

天然ガスは発熱量が約 $9,500 \mathrm{kcal} / \mathrm{Nm}^{3}$ と高く, イ オウ分の除去も比較的容易であり，圧縮しても L P ガ スのように淮化しないので，導管による天然ガスの直 接供給は理想的な都市ガス形態と考えられる。また天
然ガスを空気で稀釈したり，または変成して他の製 造ガスと混合して供給している都市ガス事業者もあ る。

その他に天然ガス産地附近の家庭で，パイプを地中 につつこんで天然ガスを採取し，炊事，暖房用に利 用している例もあるが，量的にはわずかなものであ る。

\section{(3) LPガス}

L P ガスはプロパンのほか, ブタン，プロピレン， ブチレンなぞ $\mathrm{C}_{3}, \mathrm{C}_{4}$ の炭化水素の総称である。これ らの炭化水素は, 常温常圧では気体であるが, 比較的 低い圧力でガスの $1 / 200$ 〜 $1 / 250$ 程度の容積の液体となる ので，これらのガスを簡単に液化させ，タンクやボン ベに充填して貯蔵，運搬することができる大きな特徵 がある。

L P ガスの供給源としては，(1) 原油および天然ガ スを採取する際の副産物としてL P ガス留分を分離す る。（2）石油精製工程から得られるもの（3）石油化 学工場のナフサ分解工程（エチレン製造）から発生す

\section{表 33 LP ガス需給実績および計面推移}

\begin{tabular}{|c|c|c|c|c|c|c|c|c|c|c|}
\hline$\underbrace{\text { 分 }}_{\text {区需 }}$ & 36 & 37 & 38 & 39 & 40 & 41 & 42 & 43 & 44 & 45 \\
\hline 家 庭 - 業務用 & 500 & 787 & 1,118 & 1,434 & 1,760 & 2,253 & 2,670 & 3,023 & 3,338 & 3,654 \\
\hline 都市ガス用 & 26 & 34 & 44 & 39 & 89 & 45 & 62 & 73 & 54 & 47 \\
\hline 工 業 用 & 73 & 99 & 182 & 255 & 326 & 412 & 491 & 570 & 652 & 730 \\
\hline 自動車 用 & - & - & 155 & 274 & 532 & 646 & 723 & 781 & 838 & 896 \\
\hline 化学工業用 & 98 & 115 & 86 & 64 & 52 & 214 & 191 & 198 & 198 & 198 \\
\hline 計 & 697 & 1,035 & 1,585 & 2,166 & 2,709 & 3,570 & 4,137 & 4,645 & 5,080 & 5,535 \\
\hline （対前年度比 \%) & $(65.5)$ & $(43.7)$ & $(54.0)$ & $(36.7)$ & $(25,1)$ & $(31.8)$ & (15.9) & $(12.3)$ & $(6.4)$ & $(9.0)$ \\
\hline ○供 & & & & & & & & & & \\
\hline 産 & & & & & & & & & & \\
\hline 製 油所 & 641 & 813 & 1,158 & 1,483 & 1,804 & 1,917 & 2,078 & 2,273 & 2,559 & 2,794 \\
\hline アイソマックス & - & - & - & - & 36 & 221 & 257 & 257 & 216 & 218 \\
\hline 天然ガス鉱場 & 11 & 13 & 14 & 14 & 14 & 14 & 14 & 15 & 15 & 15 \\
\hline 石油化学工場 & 80 & 138 & 209 & 273 & 408 & 470 & 530 & 554 & 570 & 592 \\
\hline 計 & 732 & 964 & 1,381 & 1,770 & 2,262 & 2,622 & 2,870 & 3,099 & 3,360 & 3,619 \\
\hline 製油所自家燃 & 25 & 53 & 21 & 56 & 66 & 71 & 76 & 82 & 86 & 91 \\
\hline 差引生産量 & 707 & 905 & 1,360 & 1,714 & 2,196 & 2,551 & 2,803 & 3,017 & 3,274 & 3,528 \\
\hline 入 & 28 & 129 & 227 & 429 & 584 & 1,049 & 1,474 & 1,742 & 1,829 & 2,040 \\
\hline 計 & 735 & 1,040 & 1,587 & 2,143 & 2,780 & 3,600 & 4,277 & 4,759 & 5,103 & 5,568 \\
\hline
\end{tabular}

注 1） 33〜37年度は「40４4年度石油供給計画」による。

2) $38 \sim 45$ 年度は「41 45年度石油供給計画」による。

3） 40 年度は一部推定を含み，41年度以降は推定。 
る $\mathrm{C}_{3}, \mathrm{C}_{4}$ 留分中, 石油化学原料分を除いた残りなど であるが，(2）からの生産が大部分で，不足分は中近 東などから輸入している。

市販されている一般のL P ガスはたとえばプロパン $70 \%$ ，ブタン $30 \%$ というような混合物であるが，こ れを自然気化させて使用するときは, 蒸気圧の高いプ ロパンは気相中に多く集まり，ボンベ中のガスは使い 終りに近づくにつれて液相中にブタンが増す。またガ スが気化する際蒸発潜熱を液化ガスから奪うので，液 温が下り，いずれも蒸気圧の減少といら現象が起こる が，家庭用は通常は断続使用であるのでさしつかえは なからう。

都市ガスに比し発熱量は高く, 理論空気量としてプ ロパンの場合ガスの 24 倍, ブタンで 31 倍を要し, 加えて, L P ガスの比重が約 1.6 と都市ガスより 2 倍以上も大きいことから, 必要な 1 次空気を吸引させ

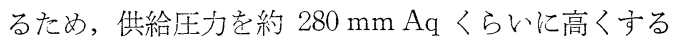
必要がある。

ガスと空気の混合物をバーナーで然燒させたとき, 炎の燃焼速度 は理論空気量の $90 \%$ くらいのときに 最大となるが，この值はプロパン，ブタンの場合それ ぞれ $42 \mathrm{~cm} / \mathrm{sec}, 38 \mathrm{~cm} / \mathrm{sec}$ で, 都市ガスの $50 \sim 70$ $\mathrm{cm} / \mathrm{sec}$ に比べ，相当に小さく，したがつてこの点か らいつても都市ガス用の然焼器具で L P ガスを燃焼さ せることはできない。またプロパン，ブタンの最大然 焼速度は天然ガス（メタン）とほとんど同じである が, 理論空気量は天然ガスの約 3 倍であるから天然ガ ス用の然焼器具と L P ガス用のそれとは共通に用いる ことはできない。

L P ガスの比重は空気より大きいため，ガスが漏油 した場合，通風の覀いところでは，床面や溝などに滞 留しがちで危険である。事実L P ガスの事故の原因は 大部分が家庭においても，作業場においても漏れたガ スに引火，爆発したものだからである。

一般家庭用の供給方式としては $10 \mathrm{~kg}$ 容器, $20 \mathrm{~kg}$ 容器または $50 \mathrm{~kg}$ 容器などで行なわれるボンベ単独方 式が通常である。集団住宅などではボンベ並列方式と いつて主として $50 \mathrm{~kg}$ 容器を多数並列設置し集合配管 とし, 容器内で自然気化させたガスを導管で供給する ことが多い。

最近数年閒の L P ガス需要は急激な伸びを示してお り, 今後の動向についても現在の傾向が続くとみられ る。

需給実績および計画を表33に示す。
III. 5. 2. 暖房用都市ガス使用量つ推移

都市ガス販売量の約 60\% は家庭用に使用されてい る。そのなかでは㴻房用に多く使われている。家庭用 ガス販売量のうち，暖房用にどの程度使用されている かといら推定は非常にむつかしいものである。考え方 として東京瓦斯の一例を簡単にのべよう。ガスを使用 している需要家数にストーブの普及率を乗じて，スト ーブの普及台数を求める。それにストーブ 1 台当たり の使用量を乘じて暖房用ガス量を推定する。暖房用販 売量の家庭用販売量に対する割合を表34に示す。

\section{表34 家庭用販売量のなかの暖房用販売量}

年月 暧房用販売量 家庭用販売量 暖房用/家庭用

$\begin{array}{rrrr} & \left(4 \mathrm{~m}^{3}\right) & \left(4 \mathrm{~m}^{3}\right) & (\%) \\ 38 / 11 & 1,536 & 75,625 & 2.0 \\ 12 & 8,371 & 93,018 & 9.0 \\ 39 / 1 & 18,812 & 125,220 & 15.0 \\ 2 & 23,631 & 126,023 & 18.8 \\ 3 & 24,901 & 124,426 & 20.0 \\ 4 & 16,316 & 101,573 & 16.1 \\ 5 & 8,246 & 83,715 & 9.9 \\ 39 / 11 & 4,737 & 87,215 & 5.4 \\ 12 & 16,003 & 114,000 & 14.0 \\ 40 / 1 & 33,936 & 148,498 & 22.9 \\ 2 & 37,687 & 140,380 & 26.8 \\ 3 & 36,822 & 140,464 & 26.2 \\ 4 & 31,260 & 131,864 & 23.7 \\ 5 & 16,656 & 110,573 & 15.1 \\ 40 / 11 & 6,041 & 93,150 & 6.5 \\ 12 & 23,760 & 125,754 & 18.9 \\ 41 / 1 & 44,233 & 172,398 & 25.7 \\ 2 & 40,422 & 157,087 & 25,7 \\ 3 & 32,432 & 146,249 & 22.2 \\ 4 & 23,991 & 133,659 & 17.9 \\ 5 & 9,772 & 113,612 & 8.6\end{array}$

III. 5. 3. 暖房 (装置) 用ガス器具

(1) 特 長

暖房(装置)用ガス器具の特長としてはつぎのような 事柄大あげられる。

（a）冷えた部屋を手軽に迅速に暖めることができ る。

(b) 部屋の温度の調節は器具栓 1 つの操作で簡単 にできる

（c）点滅は器具栓 1 つで簡単。また, ほとんどが 
自動点火装置付なのでマッチも不要。

（d） ガスの燃焼によつて水蒸気ができるので乾燥 しすぎることはない。

(e) 直接暖房においては，発生熱量が全て有効熱 量となる。

（f）燃料の䘹給，貯蔵の煩らわしさがなく，衛生 的である。

（g）暖房費は電気に比べ経済的である。

\section{(2) 種 類}

暖房 (装置) 用ガス器具は機能と構造上の違いより 大きく分けるとつぎのよらになる。

(a) スケレトン型ストーブ

角型をたは棒状スケレトンを使用する反射型ストー ブと，丸型スケレトンを使用する丸型ストーブの 2 種 にわけられる。暖房能力は, 発生熱量 $1,500 \mathrm{kcal} / \mathrm{hr}$ のものから $8,000 \mathrm{kcal} / \mathrm{hr}$ 程度のものまである。（図 23 , 図24)

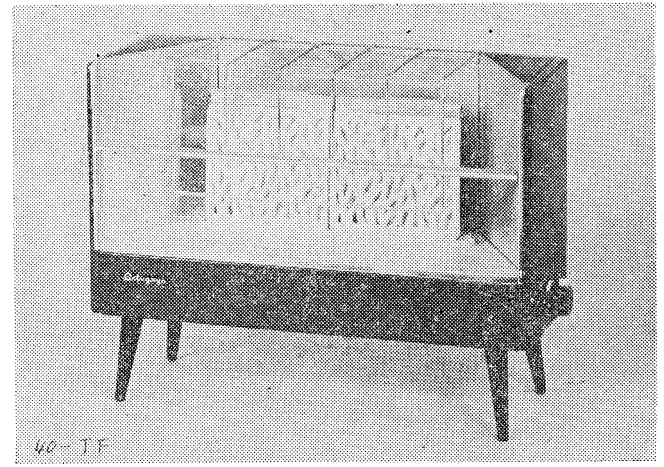

図23厓射型ストーブ

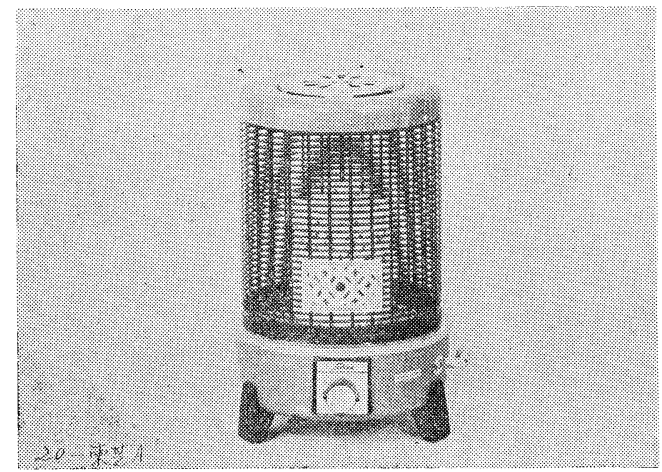

図24 丸型ストーブ （b）赤外線ストーブ

ふく射体の構造から，七ラミックプレート式と金網 式の 2 種にわけられる。床上に設置するもののみでな く天井から吊下げられる形式のものもある。

暖房能力 は, 発生熱量 $1,000 \mathrm{kcal} / \mathrm{hr}$ 加 6 , 000 $\mathrm{kcal} / \mathrm{hr}$ 程度のものまである。(図25)

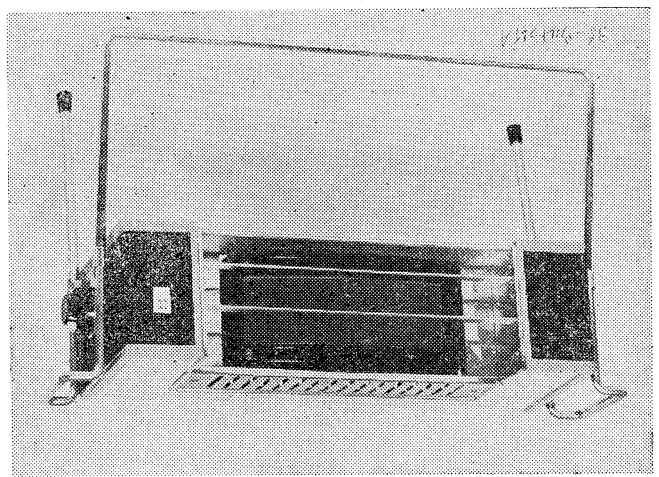

図25 赤外線ストーブ

(c) サーキュレータ

普通型サーキュレータとバランス型サーキュレータ の 2 種にわけられる。

暖房能力は発生熱量 $3.000 \mathrm{kcal} / \mathrm{hr}$ から $8,000 \mathrm{kcal} /$ $\mathrm{hr}$ 程度のものである。

なお，点火方式はほとんどが压電点火方式である が，乾電池式やマッチ点火のものも岁る。(図26)

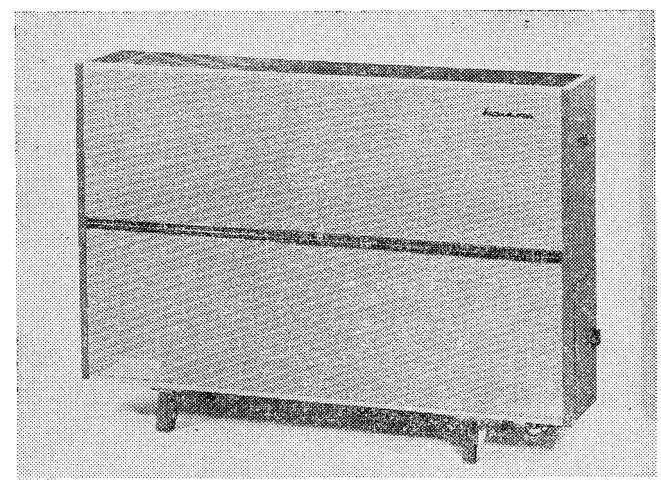

図26 サーキュレーターストーブ

\section{(3) スケレトン型ストーブ}

ふく射体としてスケレトンを用いたストーブで，こ の型式は最も古くから用いられているものである。

構造は本体, 反射板, スケレトン, バ一ナ, その他 よりできている。 
パーナで然焼して発生した熱は，スケレトンを加熱 して赤熱させる。そしてその表面から 全熱量の 15 $25 \%$ を孔く射熱として前方の広範囲に放射し，残り の熱は対流熱として上昇し，部屋全体を暖める。

したがつて, スケレトン型ストーブの特徴は, 点火 直後はふく射熱を主に，その後は徐々に部屋全体を暖 める器具といえる。

（注）スケレトン……骸骨の意味で，これ自体の形 状と，取り扱つた場合の感じなどから名づけられ たと推測される。

製法は，木節粘土 $60 \%$. シャモット粉末 $30 \%$ ， 滑石 $10 \%$ の 3 種を配合成形して 1,020 1, 060 ${ }^{\circ} \mathrm{C}$ で燒成して作る。(図27)

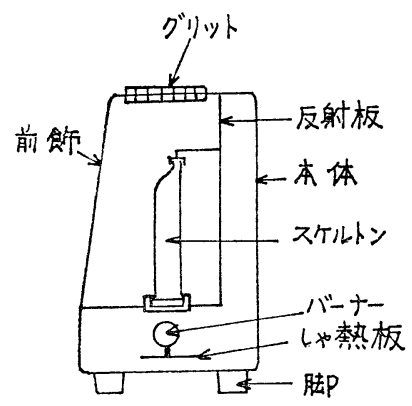

図27 反射型ストーブの構造

\section{（4）赤外線ストーブ}

赤外線ストーブは，ここ数年来めざましい普及を示 している暖房器具で, これはスケレトン型ストーブに ない数々の特長を有する他, デザインや機能が近代的 なセンスにマッチしているためである。

(a) 特 長

（i）全発熱量の $40 \%$ 前後といら多量のふく射 熱赤外線を出すことができる。

（ii）ほとんど炎を出さず静かに然える。

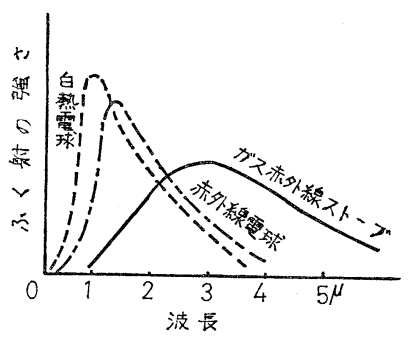

図28赤外線ストーブの波長分布 (iii）熱の方向は上下自由に変えられる。

(iv) 風の吹く屋外の暖房も可能。

(v) 波長 $2.8 \mu$ 附近の赤外線が多く含まれる ため，健康上効果がある。(図28）

(b) セラミックプレート式

ガスが燃焼し，かつ，ふく射体となる部分にセラミ ックプレートを用いた形式である。

セラミックプレートは酸化珪素を主体とした陶磁器 で, 直径 $1 \mathrm{~mm}$ 前後の小孔が多数あけられている。 ガスはプレートの表面から $2 \sim 3 \mathrm{~mm}$ くらい内部に大 つたところで然焼し，その表面を一様に赤熱する。

然焼方式は全一次空気式といわれるもので然焼に必 要な空気は燃焼前に全てガス中に混合される。(図29)

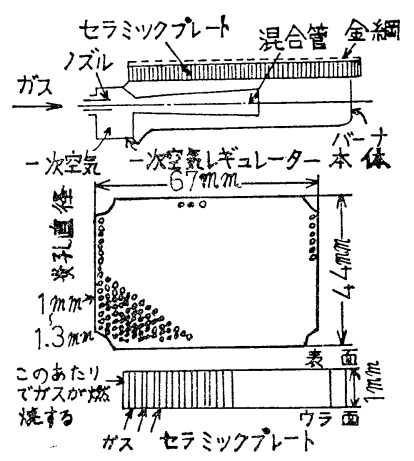

図29 セラミックプレートの構造と原理

(c) 金網式

ガスが然焼し，かつふく射体となる部分に，金網を 用いた形式である。

mesh 数の異なる数枚の超耐熱性金網を重社合せた もので，金網の形状には，ワイド形，チューブ形，丘 状形の 3 種類がある。

燃焼方式は全一次空気式である。なお，この他に， 曽状に織つた超耐熱性金網を円筒状 (一重) に加工し たものもある。(図30)

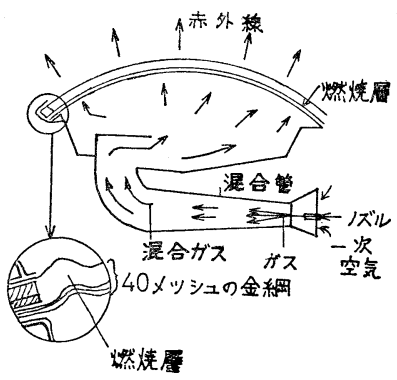

図30 金網式の構造 
（5）サーキュレータ

対流熱によつて室内を暖房する器具である。

（a） 普通型サーキュレータ

燃燒に必要な空気を設置室内からとり，燃燒廃気を 室内または室外に排出するタイプのサーキュレータ で，古くから使用されているタイプである。

構造は, 本体, 熱交換器, バーナその他よりできて いる。なお，排気筒を設置しらる構造になつている。 (図31)

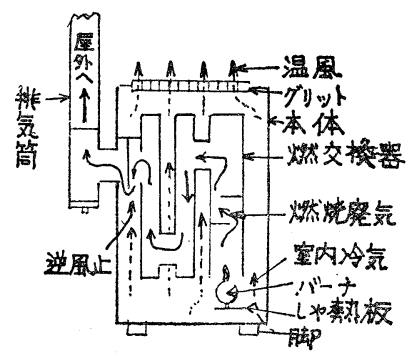

図31 普通型サーキュレーターの構造

バーナで発生した高温の燃燒ガスは, 熱交換器の内 側を通過する間に，それ自体を十分加熱する。一方室 内の冷たい空気は, その外側にはいり, 徐々に加熱さ れ上昇する。

つまり熱交換器で燃焼ガスと室内空気が熱交換され るわけである。

器具を出るときの室内空気はかなり高温となり室内 を循環して部屋全体を暖める。

普通型サーキュレータにはこのような自然対流によ る方式と,ファンを用いて暖められた室内空気を強制 的に循環させる強制対流式の 2 形式がある。(図32)

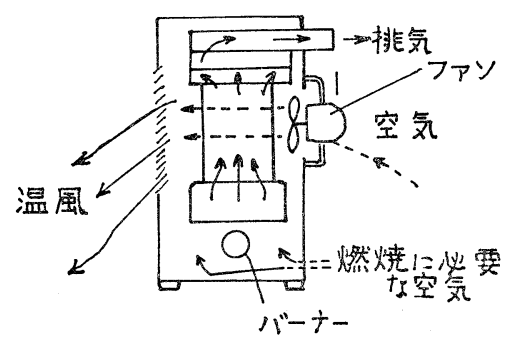

図32 ファン付サーキュレーター

特徽としてはこのように対流により徐々に部屋全体 をほぼ均一に暖房することになる。

したがつての他タイプに比べ器具の設置場所による 暖房効果の違いが少ないといえよう。

サーキュレータには，囲われた燃焼室でガスに点火
するとき, 爆発点火刀危険を防ぐため口火安全装置が 取付けられている。

（b）バランス型サーキュレータ

古くからある普通型サーキュレータに対し, 最近, 新しくできたタイプで，今後，堌々普及されると考え られるものである。(図33)

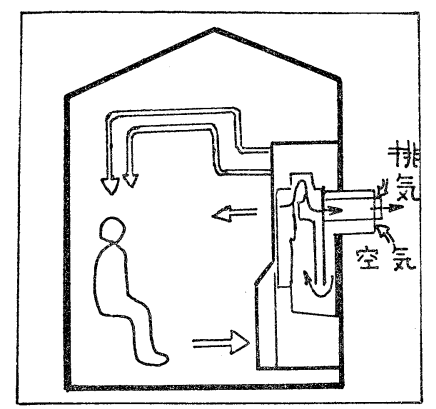

図33 バランス型サーキュレーター

普通型サーキュレータ・と異なり, 燃焼に必要な空気 を屋外からとり入れ，燃焼により生じた排気もまた屋 外に排出する構造である。

つまり, 燃焼に関与する給排気は完全に部屋から隔 絶されるわけである。

したがつて，室内の空気が污れずガス中毒の心配も なく，換気の必要むない。

給排気の機構以外の一般構造は，普通型サーキュレ ータと同じである。

部屋の温度を自動的に一定に保つルームサーモスタ ット付のものもある。

（6） ガスの違いにいる器具の違い

都市ガス，L P ガス，天然ガスと，ガスが違うとそ のガスの発熱量, 比重, 供給圧力, 燃燒性などが異な るため, 器具は同じといらわけにゆかず違ってくる。 器具の違いは，主として燃焼に関係ある部分で， ， ズル径, バーナ，セラミックプレート，金網，接続管 口径などが，それぞれのガスに適合するように作られ る。

\section{（7）注意すべき事項}

(a) 購入に際しては

（i）使用するガス用の器具であること。ガスの 発熱量も合っていること。

(ii）使用する部屋の大きさに合つた能力の器具 であること。

(b) 使用に際しては

（i）ひび割れなどの生じている古いゴム管は使 
わぬこと。また部屋越しに長いゴム管を使用し ないこと。

ゴム管は十分に差し込む。

(ii）スケレトンは正しい位置にのせる。

(iii) ガスの炎が正常の炎になるように 1 次空気 量を調節して使う。

(iv) 器具についている使用説明書をよく読み, それにしたがう。

（v）ときおり手大を行ならこと。特に炎孔部分 の掃除は必要である。
こわれたスケレトンは取りかえる。

(vi）バランス型サーキニレータ以外の器具は使 用中，時々屝や空气開汀て換気をする必要があ る。

(vii）排気筒㻍付可能のサーキュレータは,なるべ く排気筒を取付けて使用するここが望ましい。

III. 6. 電熱による暖房

電熱䲵熱源とする暖房装置としてはストーブ，めん か，こたつ，足温器などがあるが，表35に示すように あんか，こたつ類が圧倒的汇普及している。

\section{表35 暖房用電気器具の生産高*（万個）}

\begin{tabular}{|c|c|c|c|c|c|c|c|}
\hline 歴 年 & ストーブ & $\begin{array}{ll}\text { 市方 } \\
こ た つ\end{array}$ & 足 温 器 & 毛 & 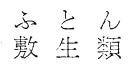 & その他** & 合 \\
\hline 昭和35年 & 37.0 & 541.4 & 19.9 & - & 29.7 & 8.5 & 636.5 \\
\hline 36 & 53.8 & 553.8 & 29.8 & 一 & 39.5 & 30.0 & 706.9 \\
\hline 37 & 21.9 & 448.9 & 24.6 & - & 40.9 & 6.1 & $548 . \frac{4}{x}$ \\
\hline 38 & 20.9 & 409.5 & 20.8 & - & 38.5 & 2.5 & 492.2 \\
\hline 39 & 29.5 & 470.8 & 14.2 & - & 36.2 & 4.6 & 553.3 \\
\hline 40 & 44.7 & 434.8 & 22.1 & 54.2 & 7.9 & 1.4 & 565.1 \\
\hline 41 & 62.2 & 509.2 & 32.9 & 88.6 & 11.3 & 2.4 & 706.63 \\
\hline
\end{tabular}

*機械統計月報

** その他暖房用, 保温用電気用品

\section{（1）電気ストーブ}

電気ストーブの発熱体は一般にニクロム線を用い, これを耐火物で支えているが，家庭用とされているも のは定格消費電力が $1 \mathrm{~kW}$ 以下が普通である。そのほ かにニクロム線を石英管に封入したもの，タングステ ン電球を発熱体としたものもある。また最近では夜間 の余橎電力を利用する蓄熱形電気ストーブも開発され ている。これは定格消費電力が $1.5 \sim 2 \mathrm{~kW}$ 程度で, 夜間の余剩電力を耐火煉瓦などに蓄熱し，昼間にこれ を放熱させるものである。さらに半導体を半熱体と し，ある一定温度以上になると半導体の電気抵抗が増 して放熱量をコントロールできるものも商品化されよ うとしている。

(2)こたつ

一般にシーズ式発熱体（直径 $0.6 \sim 1 \mathrm{~mm}$ のニクロ ム線を引き抜き鋼管または銅管内にマグネシアで絶縁 して封大したるもの）と，これに赤外線を多く照射す るよらに設計されたタングステン電球を併用したもの が多い。またこたつの定格消費電力は一般に 600W， 400W および $200 \mathrm{~W}$ の 3 段階に切り換えられるよう
になつている。

\section{(3) あんか, 定温器}

一般に直径 $0.15 \sim 0.2 \mathrm{~mm}$ 程度のニクロム線を耐 火物のボビンまたは雲母板に巻きつけたものを発熱体 としている。定格消費電力は一般に 100W 以下であ る。なお蓄熱式電気あんかと称するもので, 内部に定 格消費電力 $500 \mathrm{~W}$ 程度の発熱体を備え, 15 20分間 通電してその熱エネルギーをナフタリンに吸収させ, 通電を断つた後に徐々に放出されるナフタリンの凝固 潜熱を利用する方式のものがある。これは短時間の通 電の後は任意の場所で使用できて便利ではあるが，そ の保有熱量が 100 140 kcal で放熱量も少ないせい か，現在ではあまり生産されていない。

\section{IV. 住宅暖房に関する問題点}

\section{1. 火災に刘する安全性}

わが国における暖房用然焼器具による火災は表36に 示すとおりでストーブでは石油を燃料とするものに火 災が多い。また，こたつを使用する家庭も多いためこ 机に原因古火災多多。

しかし火贸予防のた的の規制の設けられた暖房装置 


\section{表 36 全 国火災 統 計*}

$\begin{array}{crrrrrrrrr} & \text { 火災総件数 } & \text { ストーブ } & \text { ガ } & \text { 灯 油 } & \text { 薪 } & \text { 石炭 } & \text { 火 } & \text { 鉢 } & \text { こたつ } \\ \text { 昭和34年 } & 36,913 & 865 & 63 & 221 & 344 & 189 & 331 & - \\ 35 & 43,679 & 1,168 & 77 & 401 & 383 & 240 & 381 & - \\ 36 & 47,106 & 1,621 & 94 & 825 & 446 & 198 & 366 & - \\ 37 & 49,644 & 2,398 & 142 & 1,596 & 391 & 202 & 323 & - \\ 38 & 50,478 & 2,623 & 153 & 1,858 & 367 & 169 & 348 & 1,566 \\ 39 & 49,020 & 2,588 & 149 & 1,788 & 337 & 193 & 298 & 1,603 \\ 40 & 54,157 & 2,722 & 189 & 1,844 & 398 & 117 & 307 & 1,693\end{array}$

* 自治省消防庁統計

としては,

JIS S 2019 石油ストーブ 日本工業規格

JIS S 2039 ポット式石油ストーブ

の 2 つだけである。すなわち JIS S 2019 石油ストー ブの規格では燃燒試験のほか火災予防に必要とする試 験は合計19項目規定されている。また JIS S 2039 ポ ット式石油ストーブでは同じような規定があるが，こ の式のものは移動しないので，火災予防に関する試験 は燃焼試験のほか合計 5 項目である。そのほか LPG を燃料とする暖房装置については近い将来に JIS が 制定されるはずであり，都市ガスを燃料とするものに ついては日本瓦斯協会で自主的に定めた器具検查基準 がある。以上の規格ではいずれもガスまたは燃料油 の漏洩, 発熱部以外の部分の過熱防止に重点が扝か れ，つぎに注発熱部之可燃物の接触防止に考慮が払わ れている。また電気を熱源とする暖房装置には電気用 品取締法に基づく形式認可のための試験があり，この 認可を受けたものは 四マークを付しているが，試験 は感電, 火災, 電波障害の防止などに重点が扔かれて いる。なお，燃焼ガスを直接に室内一排出する暖房装 置では炎と可燃物との接触が火災の原因となることが 多いが，煙突を使用するものでは煙突の過熱による火 災が少なくない。そのため JIS のあるものではそう した点に考慮が払われているが，JIS のないものの実 状の若干例を示すとつぎのとおりである。

(a) 石炭ストーブに煙突を図34亿示すように取り つけ, 表37亿示すようにして石炭を燃焼した場合, 煙 突取付口および煙突取出口である眼鏡石附近の燃焼ガ ス温度の一例は図35に示すとおりである。 つぎは豆炭こたつにおける各部温度の測定例である。

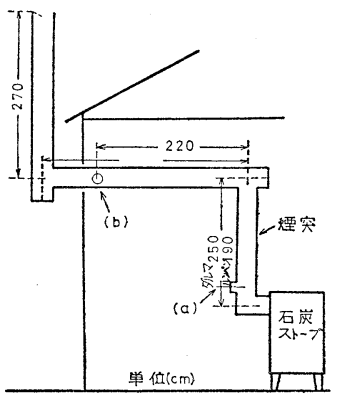

図34 煙突の配置図

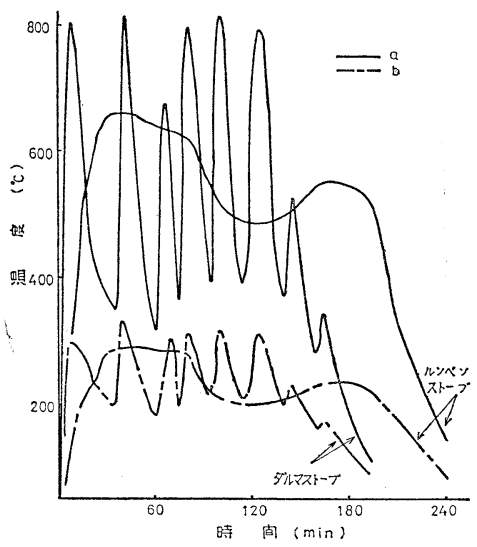

図35石炭ストーブの燃焼ガス温度

\section{表37 石炭ストーブの実験条件}

石炭ストーブ

石炭の $(\mathrm{kcal} / \mathrm{kg})$ 燃 $(\mathrm{kg} / \mathrm{hr})$
$\mathrm{A}$ (鋳物製ルンペン型)
6,190
1.7

$\mathrm{B}("$ ダルマ型)

6,980

2.3 
すなわち図36の亜炭容器に下表に示す組成の豆炭 9 個 を並べ都市ガスのこんろで約10分間加熱して 9 個の豆 炭の下半部が赤熱するのを待つてこたつ内へ装入し豆 炭こたつ内各部の温度を測つたがその結果は図37のと おりである。

\section{水 分 灰 分 揮発分 固定炭素 総発熱量} $4.6 \% \quad 18.8 \% \quad 12.8 \% \quad 63.8 \% \quad 6,200 \mathrm{kcal} / \mathrm{kg}$

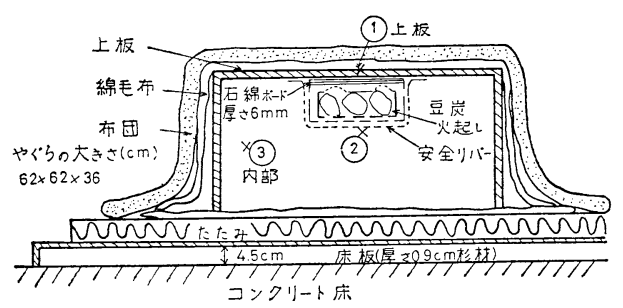

図36 豆炭こたつ

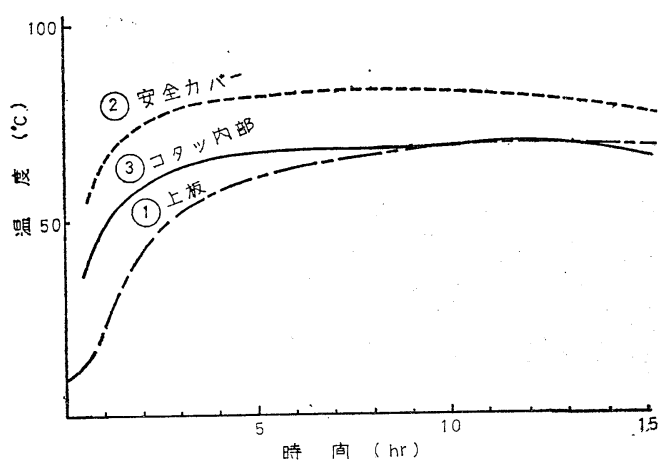

図37豆炭こたつの各部温度
すなわちこの豆炭こたつでは, 燃焼ガスで加熱され る豆炭容器の外ケース (金属製) の上部には厚さ約 $6 \mathrm{~mm}$ の石綿ポードが挿入してあるため, 布団で覆わ れた上板 (ハードボード) 附近の温度は $80^{\circ} \mathrm{C}$ 以下に 押さえられている。

\section{2. 室内空気の污染}

\section{2. 1. 各種有害ガスの許容温度}

燃焼ガスを室内に放出する形式の暖房装置では燃焼 ガスとともに各種の有害ガスが室内空気と混じて人体 に害を与えるおそれがある。死亡事故などをおこす有 害ガスは一酸化炭素であると考号れているが，それ 以外にも害を与える物質がある。

わが国も含めて各国において有害ガスの許容濃度が 定められているが，それを表38亿示す。この表でソ連 のものが著しく低い值を示しているが，これは考え方 の差異によるものであろら。他の諸国の最高許容濃度 は工場などで有害物質の出やす、条件で作業するとき これ以上は危険だといら許容濃度であるのに対し, ソ 連のものは日常生活の上でほとんど害が認められない 濃度を示したものであろら。

住居内は日常生活の場であるから, 許容濃度として はソ連式に近いものを考光た方がよいと思われる。た だし長期にわたる人体への影響を考えた許容濃度はま だよくわかつていないのでその值は確定しない。ここ では住居内の有害ガスの許容濃度として一応表38に示 されたもの (ソ連をのぞく)の $1 / 10$ 程度と考えるこ ヒにする。

なお表に示されたもの以外の燃焼によつて生じる有 害ガス, 不飽和炭化水素, アルデヒド類, 過酸化物, タール質などの許容濃度はよくわかつていない。しか したとえばきわめて微量であっても臭気などの形で人

\section{表 38 有 害物質の許容濃度}

物 質 名

\begin{tabular}{|c|c|c|c|c|c|}
\hline & 許 & 容 & 度 & p.p.m. & \\
\hline$H$ & アメリカ2) & イギリス & 西ドイッ & イタリヤ & 連 ${ }^{4}$ \\
\hline
\end{tabular}

二酸化炭素

-
100
5
5
1

5,000

5,000

一 酸 化炭素

100

50

-

二酸化イオウ

二酸化窒素

5

10

-

$\begin{array}{rr}- & - \\ 100 & 16 \\ 5 & 0.2 \\ - & 0.4 \\ - & 0.03\end{array}$

塩 素

$5 \quad 5$

-

5

1）日本産業衛生協会勧告

2) American Couference of Govermental Industrial Hygienist 委員会勧告

3) Imperial Chemical Industries の勧告值で英国で広く用いられている。

4) Office of Inspection and Technical Control of Gas Purifying Installation in Industrial Plants. 
間に不快感を与えるものも亦るので，この方面の研究 も必要である。

IV. 2. 2. 燃焼ガスによる室内空気組成の変化

第2 章にのべられているよらに暖房に必要な熱量は 換気の加熱と壁を通しての外気一の伝熱量㵒される ものである。両者の比は部屋の密閉度によつて異な る。そして室内温度と外気温度の差が等しいとき, 密 閉度の高、部屋注ど空気中に含まれる燃焼ガスの量が 多くなる。また気温の差が大きいほど燃焼ガスの割合 は大きくなる。これらの関係を炭素燃料（木炭，れん 炭) 灯油, 都市ガスについて求めたものを図 38 図 40 に示す。図中放熱数 $K A / C_{p} G$ と称するものはその值 が大きいほど密閉度が高く, 部屋から外気への伝熱が よいことを示す。またプロパンを燃料とするときは灯 油と都市ガスの中間になる。

なおこの計算注完全燃焼したガスが室内空気と完全 に混合する状態で暖房が行なわれるものとしている。 室内に人がいる場合はその発熱で然料の必要量沙な くなるが，人間も発熱と同時に酸素を消費し炭酸ガス を出すのでこの図にあまり大きな変化はない。ただし 人間から発生する水蒸気の量は 1 人 1 時間当たり 100 ～200 g に達するものでその分だけ水蒸気量が増加す る。

人がいない場合は灯油を燃焼する場合でも室内空気 は乾燥する（相対湿度が低くなる）。水素を多く含む 都市ガスを用いても湿度は少し下る傾向にある。しか

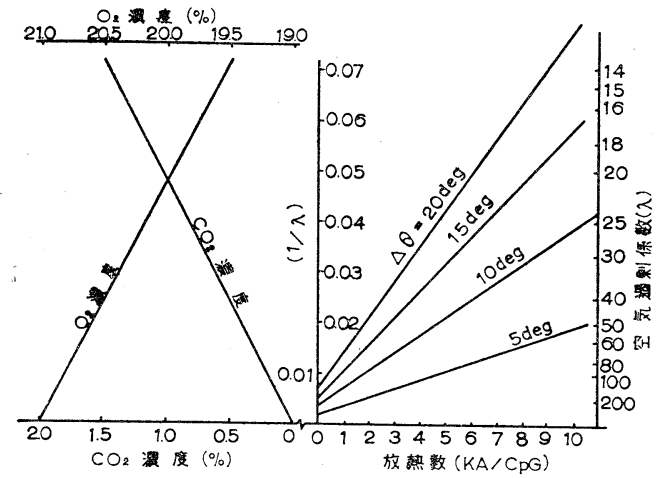

K. 熱通過率 $\left(\mathrm{kcal} / \mathrm{m}^{2}\right.$. hr. deg)

A. 放熱面積 $\left(\mathrm{m}^{2}\right)$

$G$. 換気量 $(\mathrm{kg} / \mathrm{hr})$

$C_{p}$. 空気比熱 $(\mathrm{kcal} / \mathrm{kg} . \mathrm{deg})$

$\Delta \theta$. 室内外温度差 $(\mathrm{deg})$

図38炭素を燃焼して燃焼ガスを放出する形式 の暖房装置による室内ガス濃度計算図表

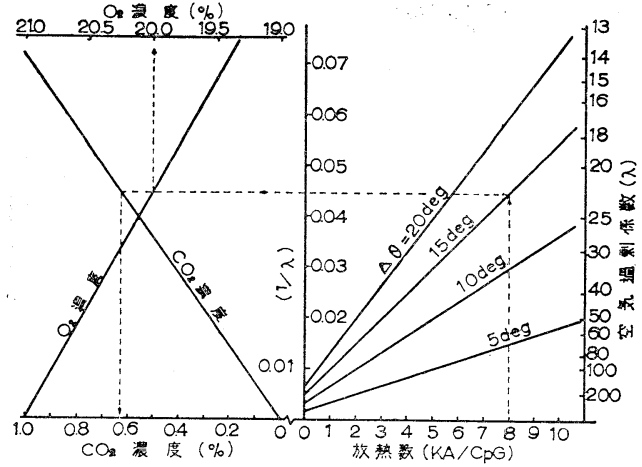

$K$. 熱通過率 $\left(\mathrm{kcal} / \mathrm{m}^{2}\right.$. hr. deg)

A. 放熱面積 $\left(\mathrm{m}^{2}\right)$

$G$. 挨気量 $(\mathrm{kg} / \mathrm{hr})$

$C_{p}$. 空気比熱 $(\mathrm{kcal} / \mathrm{kg}$. deg)

$\Delta \theta$. 室内外温度差 (deg)

図39（a）燃焼ガスを室内に放出する形式のスト ーブで灯油を燃焼するときの室内ガス 濃度計算図表

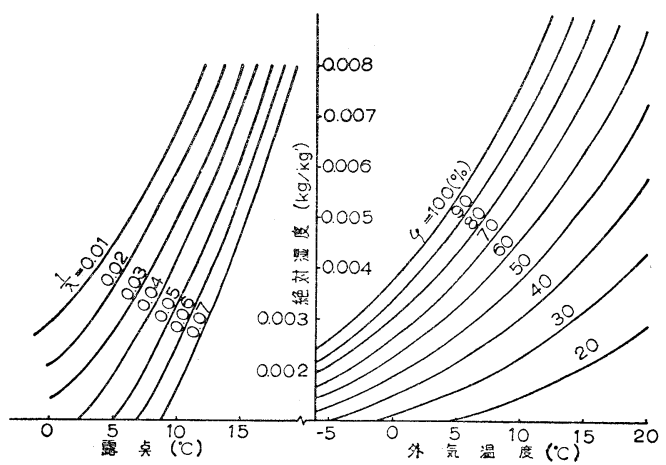

図39(b) 燃焼ガスを室内に放出する形式のスト ーブで灯油を燃焼したときの室内ガス の露点

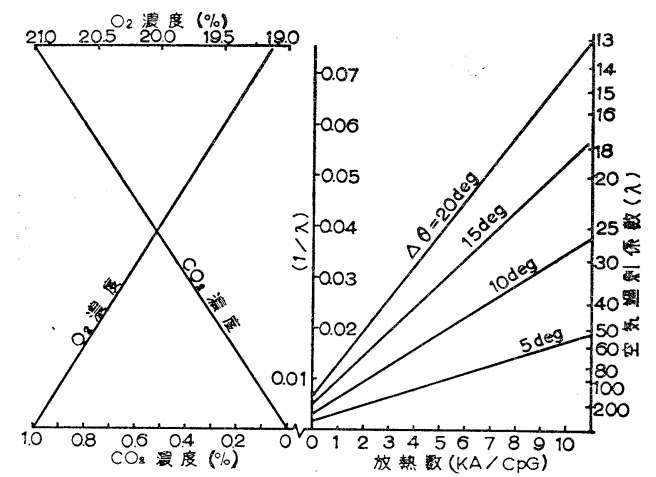

$K$. 熱通過率 $\left(\mathrm{kcal} / \mathrm{m}^{2}\right.$. hr. deg)

A. 放面熱積 $\left(\mathrm{m}^{2}\right)$

$C_{p}$. 空気比熱 (kcal/kg. deg)

$\Delta \theta$. 室内外温度差 (deg)

図40(a) 燃焼ガスを室内に放出する形式のスト 一ブで都市ガスを燃焼する時の室内ガ ス濃度計算図表 


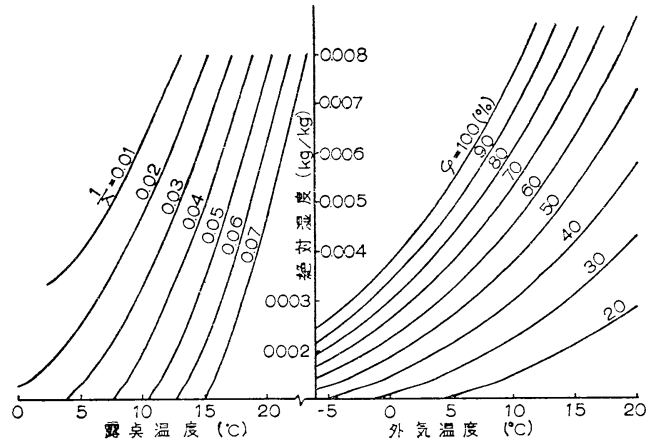

図40(b) 燃焼ガスを空間に放出する形式のストーブ で都市ガスを燃焼した時の室内のガス露点

し暖房によつて結露などの問題がおきることは実際に 経験するところである。これは外気への伝熱のよい空 わくや押入れの中などの温度の低いところへ露を生ず るものであつて，水素の多、燃料はたしかに，結露を おこしやすい。また温度の高い室内に水蒸気の発生源

（たとえば水盤中の水）があるときもこのよらなこと がおこりやすい。

IV. 2. 3. 燃焼器具から発生する有害ガス

図38などに示されるように換気がある程度行なわれ る室内であれば呼吸に影響のあるほどの酸素濃度の低 下はない。炭酸ガスもそれ自体としての毒性はないの で特に先険はない。ただしIV.2.1. で示した許容濃 度以上になることはある。

人体に有害な不完全燃燒生成物は燃焼器具の種類, 操作方法によつてその発生の状況が暴なる。その測定 に際しては有害ガスと炭酸ガスの量比を測定しておけ ば，測定位置のいかんにかかわらず，燃焼量と有害ガ ス量との関係がわかる。現在石油ストーブの燃焼ガス 中の $\mathrm{CO}$ の許容度として $\mathrm{CO} / \mathrm{CO}_{2}=0.003$ という 值が定められている。図39を用いて放熱数，(KA/ $\left.C_{p} G\right)=6$, 温度差 $15 \mathrm{deg}$ とすると $\mathrm{CO}_{2}$ 濃度は 0.4 \% となるから室内空気中の CO の限度は 13 p.p.m. となる。この值は表38の許容濃度の 100 p. p. m. の だいたい $1 / 10$ であるから一応妥当な值である。

一方崇素燃料の例として下つきれん炭火鉢を用いる とすると，その $\mathrm{CO}$ 発生量は $\mathrm{CO} / \mathrm{CO}_{2}=0.1$ 近くの 值となる ${ }^{22)}$ 。前と同様の条件をとると室内空気中の炭 酸ガスは $0.8 \%$ となり, 一酸化炭素の量は 800 p.p.m. になり，きわめて危険な状態となる。

今後各種の暖房用燃焼器具において一酸化炭素排出 の許容度がきめられると思われるが以上の点に十分考
慮がはらわれたものでなければならない。

IV. 2. 4. その他の問題点

石油ストーブなどの燃焼の試験は十分空気が供給さ れる状態で行なわれるが，密閉度の膏い部屋の中で然 焼する場合には空気中の酸素濃度自体分低下し，その 中で然焼が行なわれることもある。この場合どの程度 CO が発生しや寸くなるかについ下は十分应研究がな されていない。しかし白樺湖事件のような事故例（密 閉のよい室内で石油ストーブをつけたまま寝て全員死 亡した事件）も㐫るので今後すみやかに検討すべき問 題である。

木炭，豆炭などを燃料とするこたつは，比較的空気 の供給の悪い状態で然焼が行なわれ，CO を発生しや いと思われる。

事実嘉藤市次郎氏の研究23)によれば布団をかけたこ たつの中で炭素質然料を然焼すると $\mathrm{CO} / \mathrm{CO}_{2}$ は $1 / 10$ 程度であり， $\mathrm{CO}$ の濃度そのものも $0.1 \%$ をこえて いる。こたつの中にもぐつて烀吸すればただちに生命 に危険をおよぼし，こたつから布団と畳の間を通つて 出たガスをその近くで呼吸することす健康に有害であ ろう。

IV. 3. 暖房の効果と室内空気の混合

IV. 3. 1. 暖房の効果

暖房とは, 暖房器具を用いて建物内に熱エネルギー を供給して，居住者に適当な熱的環境を与えることで ある。しかし，与えられた熱エネルギー流，必ずしも 全部この目的に有效に衝いているとは限らない。そこ で，「暖房の效果とは，暖房の結果，居住者に適当な 熱的環境がどの程度有効に与えられているかを示すも のである。という抽象的な定義をすることにする。

居住者に適当な熱的環境を与えるためには, 居住者 に適当な温感を与えることが最も大切である。人の温 感は, 接している空気の温度, 湿度および流速, なら びに暖房器具や周壁, 天井, 床などからの熱放射によ つて左右される。したがつて, 暖房の効果をあげるに は，つぎの点に考慮を払わなければならない。

(a) 暖房器具の発熱量のうちで, 建物内に与えら れる熱量の大小 (暖房器具の熱効率)

(b) 室内の気温の分布がよく, 居住空間の気温が 適当であること。

（c）室内の空気の温度が適当であること。

(d) 室内の気流が適当で，居往空間に強いドラフ トのないこと。

（e）䁔房器具からの熱放射が居住者に当たる量が 適当であること。 
（f）室の周壁，天井，床などからの熱放射が適当 であること。

(g) 適当な換気量が保持されること。

\section{3. 2. 暖房器具の熱効率}

暖房器具に使用される燃料の発熱量のうちで, 建物 内に放散される熱量の割合を暖房器具の熱効率とい い，暖房器具の表には必ず書かれている。すなわち， 電熱器や, 燃焼ガスの室内に出る石油ストーブやガス ストーブ類は，熱効率が $100 \%$ ，煙突つきのストーブ 類では，排ガスとともにいくらかの熱量が逃げるの で，熱効率は 60〜70\%くらいになる。

暖房器具の熱効率は, 暖房の効果としばしば混同さ れていたが，これは暖房の効果の一つの要素にすぎな い。しかし，暖房の効果を考える際に第一に考えるべ き最も重要な要素であるから，この点については十分 に注意を払ら必要がある。

\section{3. 3. 室内の温度分布}

室内が直接に暖房されているときは，室内に対流が 生ずるので, 天井に近い部分の温度が高くなり, 床付 近の温度が低くなる。とくに，周壁や天井の断熱が悪 く, 撸気量が多ければ，上下の温度差は非常に大きく なる。断熱の悪い，換気の多いバラック建築では，天 井と床面付近の温度差が $15^{\circ} \mathrm{C}$ 以上になることは珍ら

\section{しくない。}

これに反し，断熱のよい，換気量の少ない室内では 温度差が小さくなる。菡41は各種の暖房をしたときの 上下温度分布の実測例である。

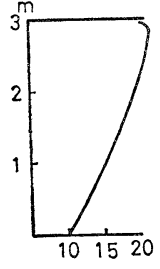

蒸気暖启

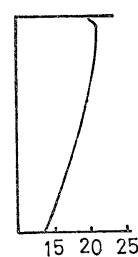

湯暖 房

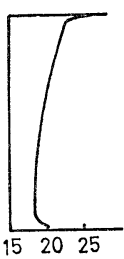

天井子く

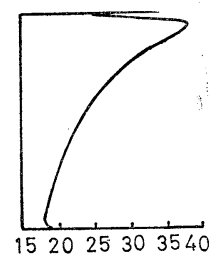

吙暖房

図41室内の荤直温度分布

上下温度分布は，頭部における温度と足部における 温度との差が $1 \sim 1.5^{\circ} \mathrm{C}$ 以内であることが望ましい が，少なくとも $3^{\circ} \mathrm{C}$ 以内にとどむべきである。住宅 などのように天年高が低い室では，天并と床面付近の 温度差は $5^{\circ} \mathrm{C}$ 以下が望ましいが，天井高が約 $4 \sim 5 \mathrm{~m}$ 以上の室では， $5 \mathrm{C}$ 以上の温度差が出ることはやむを 得ない。

水平方向の温度分布は, 暖房器具の種類とその位 置，室の形状，すき間風の侵入などによつて異なる。 この場合も, 建物の保温のよい方が分布は一様に近く なる。

室内の温度の水平分布を一様化するには, 暖房器 は，空下，外壁の下方などに配置するのがよい。

室内の温度分布を一様化する積極的な方法として， ファンを用いて強制対流を行ならことがある。ファン を別につける場合もあるが，多くの場合は暖房器具の 部分にファンをつけて, 熱交換の効率を高めるととも に，強制対流を行ならようになうている。いずれの場 合も，居住者に強い風が当たらないようにしなければ ならない。 $0.2 \mathrm{~m} / \mathrm{sec}$ 以上の気流が居住区域に生じな いよらにしなければならない。

IV. 3. 4. 熱放射

暖房器具または，室の周壁，天井，床などからの熱 放射を利用することは，暖房の効果をあげるのに非常 に有效である。とくに換気量を比較的大きくする必要 のある場合には，熱放射の利用を是非考えなければな らない。

いずれの暖房器具も大なり小なり熱放射のことを考 慮に入れているが，あまり熱放射が強いものは，換気 の少ない室を定常的に暖房するには不向きであり，熱 放射成分の小さい，対流成分の大さい器具がよい。し かし急に身体を暖ためたいときには，熱放射成分の大 きい器具がよい。

室の周壁・天井・床などの温度が低く，熱放射の小 さいときは，底冷えがして不快である。なるべく周 壁・天井・床などの断熱をよくするとともに，表面に 熱容量が小さく断熱のよい枋料を用い，短時閒の暖 房でも，表面温度が速かに上昗するようにすべきであ る。

IV. 3. 5. 喛房時の換気量

室内の空気を採つて燃焼を継続する形式の暖房器具 の場合には，燃焼が完全に行なわれるために，ある程 度の換気が必要である。各種の然料について, 理論的 の燃燒用空気量究求めると表39のようになる。

表39の換気量は, 燃焼器具に直接に供給されるもの であつて，実際の建物の換気がすべて燃焼に使用され るわけではないので，建物の換気量は，表に示した換 気量の約10倍くらい必要であるといわれている。すな わ乞，どの燃料空用いた場合でも，1,000 kcal の発熱 を得るには，約 $10 \mathrm{~m}^{3}$ の空気が必要になる。もし， $5,000 \mathrm{kcal} / \mathrm{hr}$ の暖房器具を用いているときは, 50 $\mathrm{m}^{3} / \mathrm{hr}$ の換気が必要であるが，これは一般の住宅では 


\section{表 39 燃用空気 量}

(総発熱量 $1,000 \mathrm{kcal}$ 当たり)

\begin{tabular}{|c|c|c|c|c|c|c|c|c|}
\hline \multirow{2}{*}{ 燃 } & \multirow{2}{*}{ 料 } & \multirow{2}{*}{$\begin{array}{c}\text { 燃燒用空気 } \\
\left(\mathrm{m}^{3}\right)\end{array}$} & \multirow{2}{*}{$\begin{array}{c}\text { 湿 排 気 } \\
\left(\mathrm{m}^{3}\right)\end{array}$} & \multirow{2}{*}{$\begin{array}{c}\text { 乾 排 気 } \\
\left(\mathrm{m}^{3}\right)\end{array}$} & \multicolumn{2}{|c|}{$\mathrm{H}_{2} \mathrm{O}$} & \multirow{2}{*}{$\begin{array}{l}\mathrm{CO}_{2} \\
\left(\mathrm{~m}^{3}\right)\end{array}$} & \multirow{2}{*}{$\begin{array}{c}\text { 総 発 熱 量 } \\
\text { (kcal) }\end{array}$} \\
\hline & & & & & $\left(\mathrm{m}^{3}\right)$ & $(\mathrm{kg})$ & & \\
\hline & $\mathrm{C}_{3} \mathrm{H}_{8}$ & 1.01 & 1.10 & 0.93 & 0.17 & 0.14 & 0.13 & $11,975 / \mathrm{kg}$ \\
\hline & $\mathrm{C}_{4} \mathrm{H}_{10}$ & 1.02 & 1.10 & 0.94 & 0.16 & 0.13 & 0.13 & $11,772 / \mathrm{kg}$ \\
\hline 灯 & & 1.03 & 1.04 & 0.96 & 0.14 & 0.11 & 0.15 & $11,050 / \mathrm{kg}$ \\
\hline 都 & 市 ガ & 0.85 & 1.02 & 0.82 & 0.20 & 0.16 & 0.11 & $5,000 / \mathrm{m}^{3}$ \\
\hline 木 & & 1.07 & 1.10 & 1.05 & 0.04 & 0.04 & 0.22 & $7,000 / \mathrm{kg}$ \\
\hline 煉 & & 1.08 & 1.11 & 1.07 & 0.04 & 0.04 & 0.21 & $5,400 / \mathrm{kg}$ \\
\hline
\end{tabular}

居住者のために供給する換気量にほぼ見合つたもの

IV. 4. 1. 暖房器具の普及状態

（居住者に対する換気量は $17 \mathrm{~m}^{3} / \mathrm{hr}$. 人 が標準であ （1）一世帯当たりの光熱費

り，居住者が 3 人のときは $51 \mathrm{~m}^{3} / \mathrm{hr}$ となる）である。

IV. 4. 住居暖房に関する消費者側の調查

本節でとりあげた調査資料はほとんど日本電気工業 会資料として調査されたものである。

調査地域は東京都23区および都下 8 市， 5 町村であ り，2 段確率比例抽出法により，1,200 世帯が抽出さ れた, 調查方法は面接調查で回収数 952, 回収率は $79.3 \%$ であつた。

調查実施期間は昭和 41 年 11 月 26 日から 12 月 6 日まで である。

昭和 41 年 10 月総理府「家計調査報告」によると光熱 費の全国平均は一世带 1 ケ月当たり 2,403 円, 人口 5 万 人以上の都市部では 2,411 円となっている。一方「日 本電気工業会資料」の調査を分類すると, 光熱費の月 間支出が 2,000円未満の世帯が全体の $22.7 \% ， 2,000$ 円以上 4,000円未満の世帯が 33.8\%，4,000円を越え るものが $38.5 \%$ になつている。この層の比率が大き い理由は調查に店舗併設住宅が含をれていて家庭用と 業務用の区別ができないためであろう。

（2）暖房器具の普及状態と平均使用時間（表40）

表 40 暖房器具普及率と平均使用時間

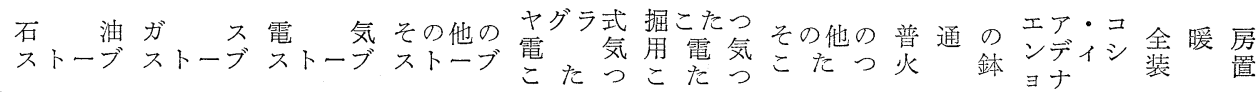

$\begin{array}{rrrrrrrrrrr}\text { 普 及率 } & 53.8 & 33.5 & 24.0 & 2.9 & 80.2 & 7.3 & 15.8 & 28.6 & 0.5 & 0.5 \\ \text { 使用使間 } & 10.30 & 8.00 & 5.00 & 5.30 & 9.30 & 10.00 & 11.00 & 11.30 & 12.00 & 10.30\end{array}$

電

\begin{tabular}{|c|c|c|c|c|c|c|c|c|c|c|}
\hline 及 率 & 33.6 & 10.3 & 9.1 & 1.8 & 0.2 & 0.7 & 0.2 & 0.9 & 0.1 & 0.1 \\
\hline 使用時間 & 6.30 & 7.30 & 3.30 & 5.00 & 4.00 & 6.30 & 9.30 & 5.30 & 0.30 & 3.00 \\
\hline
\end{tabular}

普及率の最高は $80.2 \%$ のヤグラ式の電気こたつ, つぎが石油ストーブの $53.8 \%$, 三位がガスストーブ の $33.5 \%$ となつており, 電気ストーブは $24.0 \%$ で，現在斜陽的燃料といわれている木炭使用の火錸は 電気ストーブを上迴る $28.6 \%$ である。

平均使用時間の多い用具は, 石油ストーブ，こたつ 類, 火鉢, エアコンディショナ, 全暖房装置があげら れる。現在のところエアコンディショナ, 全暖房装置

の普及度はきわめて低いが, 器種の性格として今後生 活様式の伸展変貌にともなつて普及率も高主り使用時 間も当然長くなるものと思われる。ストーブ類では普 及率が最高の石油ストーブが使用時閒も長い。

(3) 家庭条件による器具普及状況

(a) 家族構成によるもの

表41は家族構成による暖房器具の所有率の違いを示 しているが石油ストーブ, ガスストーブは家族構成と 
いうよりもむしろ家族員数により多く関係しているとく所有されている。 思われる。電気毛布と普通火鉢法老人のいる家庭に多

\section{表 41 家族構成による暖房器具普及度}

\begin{tabular}{|c|c|c|c|c|c|c|c|c|c|c|c|c|}
\hline 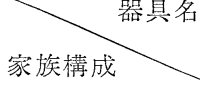 & サンプル数 & $\begin{array}{l}\text { 石油ス } \\
ト \text { トーブ }\end{array}$ & 方スス & $\begin{array}{l}\text { 電気ス } \\
\text { トーブ }\end{array}$ & $\begin{array}{l}\text { のスト } \\
\text { ーブ }\end{array}$ & $\begin{array}{l}\text { 式 } \\
己 7\end{array}$ & & $\begin{array}{l}\text { のこた } \\
\text { つ }\end{array}$ & $\begin{array}{l}\text { 普这 } \\
\text { 火金 }\end{array}$ & $\begin{array}{l}\text { 電 気 } \\
\text { あ九名 }\end{array}$ & 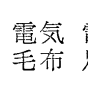 & 温 \\
\hline & $100.0(591)$ & 53.8 & 33.5 & 24.6 & 9 & 80.2 & 7.3 & 8 & 28.6 & 6 & 10.3 & 9.1 \\
\hline 婦 だ & $"$ ( 71) & 26.8 & 25.4 & .3 & 4 & 88.7 & 5.6 & 4.2 & 31.0 & 16.9 & 8.5 & .2 \\
\hline 子供 & " (596) & 53.9 & 32.4 & 23.2 & 3.2 & 81.4 & .5 & 13.3 & 25.2 & 34.1 & 7.0 & 6 \\
\hline 子供 & $"$ (144) & 66.7 & 42.4 & 34.0 & 4.2 & 77.8 & 10.4 & 21.5 & 34.0 & 39.6 & 22.2 & \\
\hline 婦 老 & " (14) & 50.0 & 50.0 & 50.0 & - & 78.6 & 7.1 & 21.4 & 42.9 & 50.0 & 14.3 & \\
\hline . & " (9) & 77.8 & 22.2 & - & - & 55.6 & - & 11.1 & 55.6 & 22.0 & 22.2 & \\
\hline 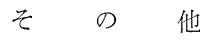 & " (117) & 53.0 & 32.5 & 22.2 & 1.7 & 74.4 & 8.5 & 28.2 & 34.2 & 33.3 & 12.0 & \\
\hline
\end{tabular}

普及度の低いものは分類の意味がないので省略した（以下同様）

(b) 住居条件によるもの

表42で明らかなようにヤグラ式電気こたつはどのグ ループでも大体等しく $80 \%$ 近くあるいはそれを上迴 る所有率を示している。一方ストーブの所有率は石
油, ガス, 電気の順位となつていて, 普及の姿として は個人の住居, 団地, マンションなどに早く普及して いることが調査の結果わかつた。

\section{表 42 住居条件と暖房器具普及度}

器具名 住条件 サンプル数 石油ガス電気他の 只グラ スドードードスト こ式電気
堀こた つ用電その他 こたっ 火鉢
エア・全体暖電 気 電気 電 気 イショ公・㕕んか毛布足温器

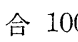

2

3

4

5

6

7
$80.2 \quad 7.3$

$15.8 \quad 28.6$

0.5

0.5

33.610 .3

9.1

" (439) $65.635 .328 .0 \quad 2.5$

75.2

10.5

$22.3 \quad 28.0$

0.5

0.9

39.013 .0

10.9

" ( 96 ( $42.721 .915 .6 \quad 4.2$

82.3

1.0

$13.5 \quad 39.6$

-

- 28.05 .2

4.2

") (166) $34.324 .1 \quad 10.2 \quad 1.8$

84.3

1.2

$9.0 \quad 21.7$

$-$

- 22.34 .8

2.4

" ( 31$) 38.754 .8 \quad 9.7 \quad$ -

$80.6-$

6.516 .1

$85.7-$

$-\quad 7.1$

$-$

$-$

$32.3 \quad 6.5$

6.5

" ( 14) $42.964 .3 \quad 14.3$ -

" (186) $53.839 .834 .9 \quad 5.4$

86.0

10.8

$11.3 \quad 36.0$

1.6

$-$

42.914 .3

7.1

" ( 19) $42.115 .8 \quad 15.8 \quad$ -

89.5
5.321 .1

注）住条 件

1. 住居専用の家屋で 1 戸建。

2. 住居専用の家屋で 2 戸建以上の普通の住宅。

3. 住居專用の家屋で 2 世帯以上入居している木造アパート。

4. 住居専用の家屋で 2 世带以上入居している鉄筋アパート（公団，公社団地アパート）

5. 住居専用の家屋で 2 世带以上入居している鉄筋アパート（その他のアパート，マンションなぼ）

6. 自営の店舗, 工場，事務所などと住宅が同一敷地内か棟続きの家屋。

7. その他（6の自営でない場合など）

(c) 職業条件によるもの

職業と暖房器具保有状況をみると表43の示すように 石油ストーブとヤグラ式電気こたつについてはどの職
業層も比較的高い所有率であるが, ガスおよび電気ス トーブは商工サービスなどの自営業者 4 および 1,2 , 3 層の保有が多い。 
表 43 職業条件と暖房器具普及度

器具名

職業条件
サンプル数

合 $100.0(951)$

石油スガスス電気スその他ヤグラ堀こた のスト式電気気こた

総

" $(35)$
$"(53)$
$"(86)$
$"(259)$
$"(240)$
$"(216)$
$"(61)$
トーブトーブトーブ ーブ 气の他 普 のこた

$\begin{array}{lll}57.9 & 33.3 & 23.8\end{array}$

$\begin{array}{lll}74.3 & 65.7 & 57.1\end{array}$

$2.5 \quad 81.5$

7.3

15.8 火鉢㐫儿か毛布足温器

\section{2}

$\begin{array}{lll}73.6 & 50.9 & 34.0\end{array}$

$2.9 \quad 77.1$

20.0

5.7

28.1

33.6

10.3

9.1

$\begin{array}{lll}80.2 & 52.3 & 34.9\end{array}$

$3.8 \quad 73.6$

15.1

20.8

24.5

34.3

22.9

14.3

$\begin{array}{lll}4.7 & 91.9 & 11.6\end{array}$

15.1

27.9

56.6

22.6

35.8

$\begin{array}{lll}59.5 & 34.0 & 31.3\end{array}$

2.7

83.4

9.3

13.1

29.7

39.0

14.0

16. 3

$\begin{array}{lll}57.5 & 30.4 & 17.9\end{array}$

$2.9 \quad 81.7$

4. 2

16.7

26.3

29.6

13.1

11.6

6

$\begin{array}{ll}42.1 & 19.0\end{array}$

11.1

1. 4

80.6

2.8

15.3

26.9

20.8

4. 6

4.2

$6.5 \quad 27.4$

40.3

27.4

14.5

3.2

注）世帯主職業条件

1. 中企業以上の重役, 大企業の上級幹部, 事務所を持ち, やとい人を置いている弁護士, 公認会計士, 病 院，医院を経営している医師度じの独立專門職の人。

2.中企業以上の管理職, 専門職（部長級）および大学教授，評論家なぞ自由業の人。

3. 中企業以上の監督職 (倸長, 課長級) 一般專門職, 小学, 中学, 高校の先生や, これに類した人。安た 弁護士，会計士の事務所にいる人。

4. やとい人を持っ自営商店主，自営工場主，自営サービス業主（飲食店や理髪店など）の人。

5. 監理職でない一般事務系給料生活者。労務系給料生活者の監督者。技術労務職に㟩る人。

6. 一般労務系給料生活者, 商店やサービス業に勤務している人など。

7. 臨時やといの労務者, 失業中の人, 無職の人など。

（d）収入条件によるもの（表44）

収入形態に扔いても石油ストーブ，ヤグラ式電気こ たつの 2 器種についてはどの階層においてもほとんど 同程度に保有状態を示している。電気めんか，電気毛 布は個人の暖身用具として給料生活者層にその保有が
高いが，5，6，7 この層を含めての階層においてはガ ス，電気ストーブの保有率は非常に低い。

（参考）家族条件，住条件，職業条件，収入形態と 光熱費支出との相関を表 $45 \sim 48$ に示す。

\section{表 44 収入形態条件と暖房器具普及度}

器具名

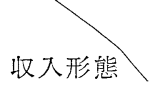

石油スガスス電気スその他中グラ堀こたその他普通電気電気電 気 サンプル数 のスト式電気気こたのこた

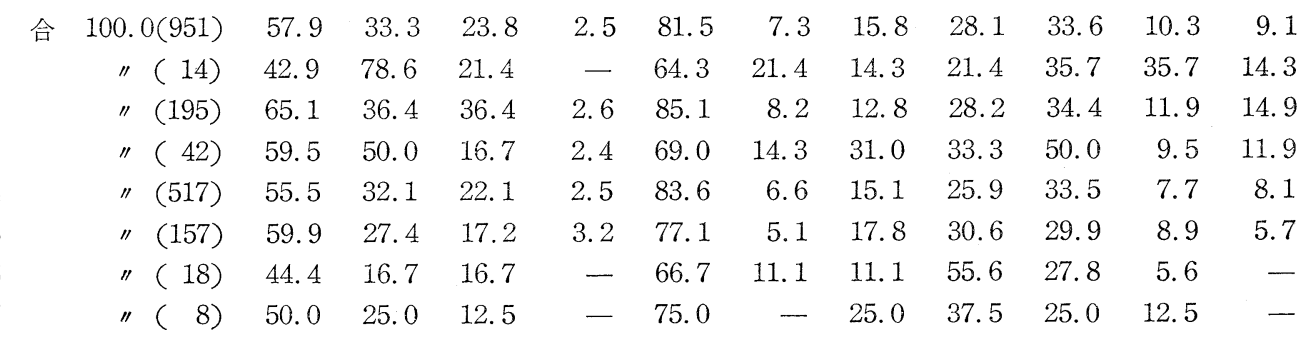

注）収大形態

1. 収入の大半が相続財産によるもの, および投資による利益, または利子収入である場合。

2. 収入の大半が事業収入や独立專門職としての収入がある場合。

3. 給与所得が 5 割以上であるが，その他に少なくとも全収入の 2 割は不動産所得，利子所得，あるいは原 稿料，出演料などの収入がある場合。

4. 給与所得が全部，あるいは大部分（大体 $80 \%$ 以上）である場合。

5. 収入の大半が請負仕事，あるいは販売の手数料などによつている場合。

6. 両親, 親類, 知人などから経済的援助をらけ, 同時にアルバイト, パートタイムの仕事などで一部を補 つている場合。

7. 公的，るるいは私的生活保護をうけている場合。 
表 45 家族条件と光熱費支出の相関

\begin{tabular}{|c|c|c|c|c|c|c|c|c|}
\hline & & & 家 & 条 & 件 & & & \\
\hline & サンプル数 & 夫婦だけ & $\begin{array}{l}\text { 夫螮 } \\
\text { 子供だけ }\end{array}$ & $\begin{array}{l}\text { 夫婦 } \\
\text { 子供 } \cdot \text { 老人 }\end{array}$ & $\begin{array}{l}\text { 夫婦 } \\
\text { 老人だけ }\end{array}$ & 老人だけ & そ & \\
\hline 合 & $100.0(951)$ & 7.0 & 59.7 & 14.5 & 1.4 & 0.9 & & 11.7 \\
\hline $\begin{array}{l}\text { 低 } \\
(2,000 \text { 円 芰泗) }\end{array}$ & "I (205) & 18.0 & 64.9 & 4.9 & 0.5 & 1.5 & & 10.2 \\
\hline $\begin{array}{l}\text { 標 準 芰出層 } \\
(2,000 \sim 4,000 \text { ) }\end{array}$ & " (351) & 4.8 & 67.0 & 10.8 & 1.7 & 1.7 & & 14.0 \\
\hline $\begin{array}{l}\text { 高 支 } \\
(4,000 \text { 以上 })^{\text {層 }}\end{array}$ & " (350) & 3.7 & 57.1 & 25.7 & 1.7 & 0.0 & & 11.7 \\
\hline 明 & $"(45)$ & 8.9 & 62.2 & 13.3 & 2.2 & 0.0 & & 13.3 \\
\hline
\end{tabular}

\section{表 46 住条件と光熱費支出の相関}

\begin{tabular}{|c|c|c|c|c|c|c|c|c|c|}
\hline 総 & & $100.0(951)$ & 46.3 & 10.3 & 17.8 & 3.7 & 2.0 & 20.2 & 2.7 \\
\hline 支出層 & (2,000円未満) & " (205) & 24.4 & 16.6 & 48.8 & 1.5 & 2.4 & 2.0 & 4.4 \\
\hline 淮支出層 & $(2,000 \sim 4,000$ 円 $)$ & (351) & 55.6 & 11.7 & 14.2 & 5.7 & 2.2 & 9.4 & 1.4 \\
\hline 支出 & $(4,000$ 円 以上) & " (350) & 50.3 & 4.9 & 2.6 & 2.6 & 0.6 & 40.0 & 0.0 \\
\hline & & (45) & 40.0 & 8.9 & 15.6 & 4.4 & 0.0 & 20.0 & 11.1 \\
\hline
\end{tabular}

*住条件の分類は表 42 参照

訔 47 職業条件と光熱費支出の相䦥

\begin{tabular}{|c|c|c|c|c|c|c|c|c|c|}
\hline 合 & & $100.0(951)$ & 3.7 & 5.6 & 9.0 & 27.2 & 25.7 & 22.7 & 6.5 \\
\hline 民支出層 & ( 2,000 円未満) & $" \quad(205)$ & 0.5 & 3.8 & 3.9 & 4.4 & 46.9 & 51.8 & 8.3 \\
\hline 隼支出層 & $(2,000 \sim 4,000$ 円 $)$ & " (351) & 1.7 & 3.7 & 11.3 & 19.3 & 35.3 & 21.0 & 7.6 \\
\hline 出詹 & ( 4,000 円以上) & $" \quad(350)$ & 8.3 & 8.8 & 9.7 & 47.7 & 14.0 & 7.2 & 4.3 \\
\hline 明 & & " (45) & 2.2 & 2.2 & 6.7 & 31.1 & 26.7 & 24.4 & 6.7 \\
\hline
\end{tabular}

*職業条件の分類注表 43 参照

表 48 収入形態と光熱費支出の相関

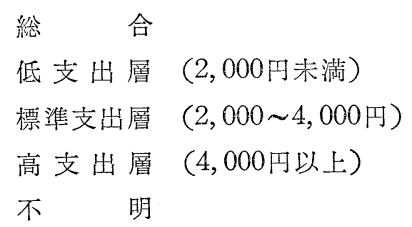

\begin{tabular}{|c|c|c|c|c|c|c|c|}
\hline & 収 & 入 & & 形 & 態* & & \\
\hline サンプル数 & 1 & 2 & 3 & 4 & 5 & 6 & 7 \\
\hline $00.0(951)$ & 1.5 & 20.5 & 4.4 & 54.4 & 16.5 & 1.9 & 0.8 \\
\hline$" \quad(205)$ & 0.5 & 2.4 & 2.0 & 78.5 & 11.2 & 3.4 & 2.0 \\
\hline " (351) & 1.7 & 1.1 & 6.6 & 62.1 & 15.7 & 2.0 & 0.8 \\
\hline$" \quad(350)$ & 1.7 & 40.3 & 4.0 & 32.9 & 20.0 & 0.9 & 0.2 \\
\hline$" \quad(45)$ & 2.2 & 22.2 & 2.2 & 51.1 & 20.0 & 2.2 & \\
\hline
\end{tabular}

*収入形態の分類は表 44 参照 
IV. 4. 2 暖房器具使用実態

(1) 暖房器具の定置および移動使用

従来室内暖房器具はほとんどが部屋に固定して使用 されていたが, 最近の生活様式の変化と新製品の出廻

\section{表49 暖房器具固定使用・移動使用}

器具名
石使用態様
ガ ス
ス
サンプル数 固 定 移 動 $(\%) \quad(\%) \quad(\%)$ . $0(796)$ " (394) $75.6 \quad 24.4$ " (240) $67.9 \quad 32.8$ " ( 24$) \quad 87.5 \quad 12.5$ " (858) $\quad 89.8 \quad 10.2$ " ( $\begin{array}{lll}56 & 98.2 & 98.8\end{array}$ " (135) $97.2 \quad 2.2$ " (148) $68.2 \quad 31.8$ "(5) 100.0 " ( 5) 100.0 -
りとによつて移動使用される器種もふなりある。コン セントさえあれば電気ストーブ，特にヤグラ式霞気こ たつは移動が可能である。それにもかかわらず表49の 示すように電気こたつの移動使用度は電気ストーブに 比して約 $22 \%$ 少ないということはこたつを置く部屋 が各家庭ではこれまで慣習的にほとんざ定まつている からであろう。コンセントもまた配管も必要としない 石油ストーブが種々問題点を持らながら移動使用され ている世帯数はその $1 / 3$ 以上 $33.5 \%$ におよんでい る。

\section{（2）暖房器種と使用の場所（表50）}

暖房はストーブに限らずすべてが居䦔での使用率が 高いのは当然であるが, 特に霆気ストーブは清絜, 衛 生的，かつ安全性の面から子供部屋での使用度が35.4 \%と他の器種にくらべて著しく高い。こたつ類活 とんどが居間で，それは固定使用であり，ストーブが 各部屋に普遍的に使用されるのに対して和宣の採暖と しての特巽性を持つものといえよう。

\section{表 50 暖 房器具の使用場所}

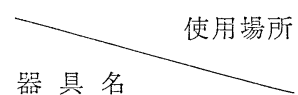
サンブル数 居 間 書 斉 部 屋

(\%)

(\%)

石油ストーブ

100.0(796)

60.4

1. 9

(\%) 応接間

"I (394)

53.4

5.1

17.1

(\%)

寝 室

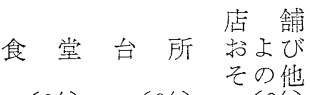

ガスストーブ

" (240)

42.9

4.2

10.9

12.1

(\%)

(\%)

$(\%)$

$(\%)$

電 気 ストーブ

" (24)

54.2

35. 4

16.5

5.2

10.2

4. 3

19.6

その伍のストーブ

-

4.2

15.8

7.6

13.5

4. 6

11.9

" (858)

87.1

0.2

16.7

11.7

2.9

1.7

7. 1

ヤグラ式電気こたつ

9.7

2.7

4.2

8.3

20.8

" ( 56) 91.0

1.8

$-$

2.9

1. 4

0.1

2.3

" (135)

74.1

0.7

1.8

3.6

$-$

1.8

その他のこたつ

" (148)

0.7

6.1

12.8

20.1

2.2

0.7

2.2

4.1

3.4

3.4

8.1

（3）一日の生活と暖房器種

われわれの生活と住暖房使用の形態をみよらとした ものが表51である。

朝食時の暖房は $91.5 \%$ とそのほとんどが暖房して いるのに対し, 起床時, 炊事時の暖房はわずかであ る。使用器具としては石油ストーブが最高で $50 \%$ 前 後であり, 器種の性格上電気採暖は $20 \%$ そ下䞟つて いる。ガスストーブは石油ストーブについで $30 \%$ 前 後の使用度である。

昼閒の暖房については食事時と日中はほぼ等しく， 暖房有りが $80 \%$ で, 器具はヤグラ式電気こたつが最 高で 50\%を上廻り，かつ食時中は連続使用である。 日中は連続使用と点滅使用が相半ばしている。

夜閒の炊事時は朝や昼と同様に少ないが，食事時と 家族団らん時注とんどが暖房をしている。その場合 の使用器具はヤグラ式電気こたつが最も多く,ついで 石油，ガスストーブの順位になつている。

睡眠中はその約 $1 / 2$ が何らかの直接暖房身器具を用 いている。こ礼付対して就寝前に部屋を暖めておくと いつた習慣は全体の $15 \%$ 程度で，ふとんの中を暖め ておくといら暖房習慣がまだまだ中心になつているよ らである。また主人の仕事部屋の暖房では石油ストー ブが $58 \%$ で最高を示し，しかも連続使用が $84.2 \%$ にも達する。ガスストーブも同様の使用形態である が，使用度注石油の約半分の $26.1 \%$ である。

来客時の暖房は“無”が $75.2 \%$, “有”が $24.8 \%$ 


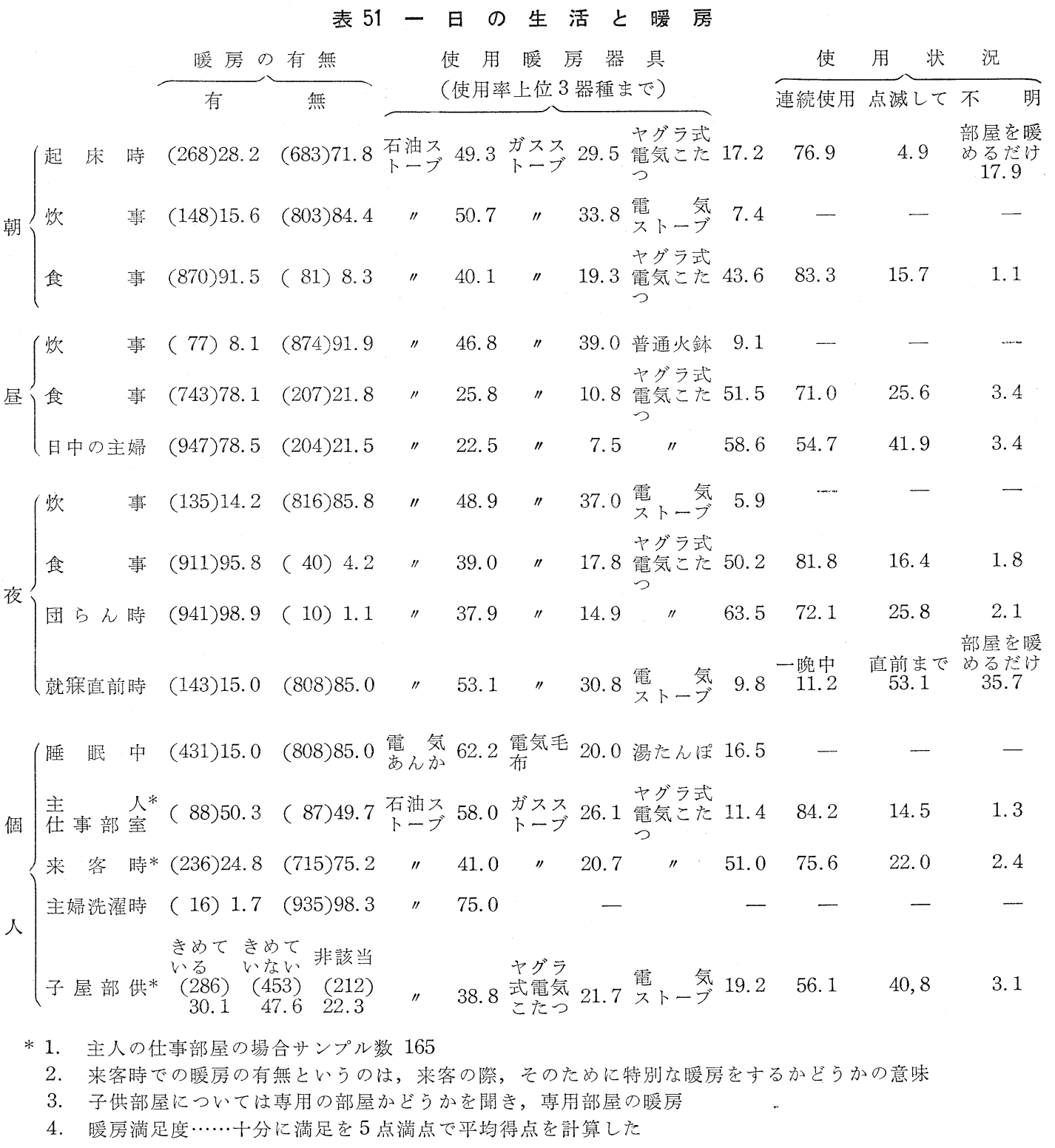

で使用器具はヤグラ式電気こたつ，石油ストーブが多 い。子供部屋の場合は電気ストーブが $19.2 \%$ ，ヤグラ 式電気こたつが $21.7 \%$ であわせて電気暖房が 40.9 \%，石油ストーブが $38.8 \%$ と集計されている。

このよらに一日の生活と暖房器具の相関を検討寸る と, 夕食後の家族団らん時は各自の家庭にとつて最も 妥当な暖房がなされているとみてよからう。こうした 見地からその団らん時に $60 \%$ 以上の使用率を持つて いる「ヤグラ式電気こたつ」は，東北，北海道といつ た寒泠地域を除けば，現在におけるわが国の典型的な
採暖様式を示すもののようである。

IV. 4. 3. 暖房様式 (器具) 選定の基準

（1）暖房エネルギの種類に対する消費者の評価 表52，表53は家庭暖房エネルギ（ガス，電気，石 油）についての消費者の評価である。その結果におい てはほとんど格差がなかつたが，暖房を冬期の必須条 件にしている北海道地区の評価では，長年月それのみ に依存していた石炭と最近出趈つた石油の評価が非常 に高いことがわかる。 
表52 家庭エネルギ（ガス，電気，石油）

消費評者価

\begin{tabular}{|c|c|c|}
\hline \multirow[t]{3}{*}{ 組合せ } & サンプル数と \% & $\begin{array}{l}100.0 \\
(951)\end{array}$ \\
\hline & 電気の方がずつと良い & 15.8 \\
\hline & 電気の方がやや良い & 24.0 \\
\hline \multirow[t]{5}{*}{ 電気とガス } & どちらでも同じ & 14.6 \\
\hline & ガスの方がやや良い & 32.2 \\
\hline & ガスの方がずっと良い & 13.5 \\
\hline & ガスの方がずっと良い & 18.7 \\
\hline & ガスの方がやや良い & 26.6 \\
\hline \multirow[t]{5}{*}{ ガスと石油 } & どちらでも同じ & 8.8 \\
\hline & 石油の方がやや良い & 32.4 \\
\hline & 石油の方がずつと良い & 13.5 \\
\hline & 石油の方がずっと良い & 21.2 \\
\hline & 石油の方がやや良い & 27.3 \\
\hline \multirow{3}{*}{ 石油と電気 } & どちらでも同じ & 9.6 \\
\hline & 電気の方がやや良い & 26.1 \\
\hline & 電気の方がずっと良い & 15. \\
\hline
\end{tabular}

\section{（2）暖房器具選定の 7 要因の解析}

表 54 によると暖房器具選定に当たつては 7 要因中 まず安全性を，ついで経済性と便利性を要求してい る。

熱の強さ，スマートさ，合理性といつた因子は二次 的要因となつている。もちろん北海道地区では熱の強 さに多くのウェイトが認められるのは当然と考えられ る。

さらにこの基準条件因子は各家庭の個性にもより， 経済性を一位にあげる階層もある。

しかし火災が一家を破滅におとしいれることもしば しばあることを消費者はよく知つて，石油ストーブが 非常に普及した現在安全性を第一に考えるようになつ たものと思われる。

一方生活様式が変化し，合理的な生活という考えが ゆきわたつたこと，共働き家庭が増したこと，など により便利性を重んずるようになつたものと思われ る。

表 53 暖房燃料の比較（経費, 安全性, 便利性・衛生性)

北海 道 地 域

$$
\frac{\text { 電気 }}{\text { ずっと良い }} \underbrace{\text { 方 }}_{\text {やや良い }}
$$

どちらも同じ

$$
\begin{array}{llll}
7.4 & 10 & 18.5 \quad 25
\end{array}
$$

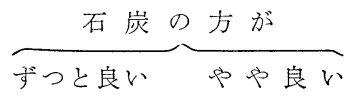

石炭と石油

$$
\begin{array}{llll}
16.3 & 22 \quad 22.2 \quad 30
\end{array}
$$

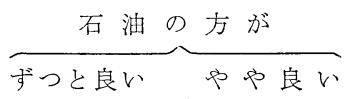

石油とガス
9.613
42.257

$\overbrace{\text { ずつと良い }}^{\text {ガス方が }}$ ガスと電 気

$$
7.4 \quad 10
$$

40.855

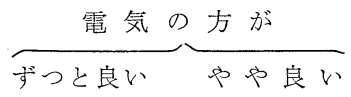

電気と石油

$\begin{array}{llll}5.9 & 8 & 19.3 \quad 26\end{array}$

$\overbrace{\text { ずっと良い }}^{\text {石炭 }} \underbrace{\text { 良い }}_{\text {や方が }}$

石孷とガス
31.142
$37.0 \quad 50$

どちらも同じ

\section{3. $0 \quad 4$}

どちらも同じ

8.512

どちらも同じ

13. 318

ぞちらも同じ

$29.6 \quad 40$

3. $7 \quad 5$

どちらも同じ

$8.9 \quad 12$

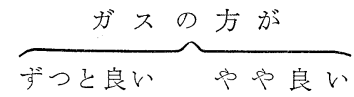

$\begin{array}{llll}19.3 & 26 & 3.7 & 5\end{array}$

$\begin{array}{llll}19.3 & 26 & 3.7 & 5\end{array}$ $\overbrace{\text { ずつと良い }}^{\text {電気 }} \underbrace{}_{\text {や方い゙ }}$

$20.7 \quad 28 \quad 1.5 \quad 2$

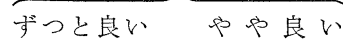

$\begin{array}{llll}56.3 & 76 & 14.8 \quad 20\end{array}$

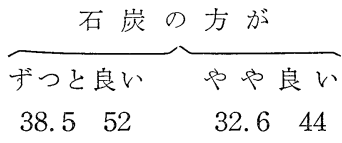

$\overbrace{\text { ずつと良い }}^{\text {石油 }} \underbrace{\text { 良い }}_{\text {や方が }}$

$\begin{array}{llll}44.5 & 60 & 8.1 & 11\end{array}$




\section{表 54 暖 房 器 具 選 定 理 由}

\section{A. 家 族 条 件}

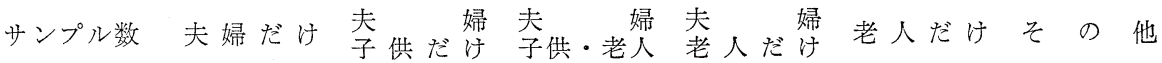

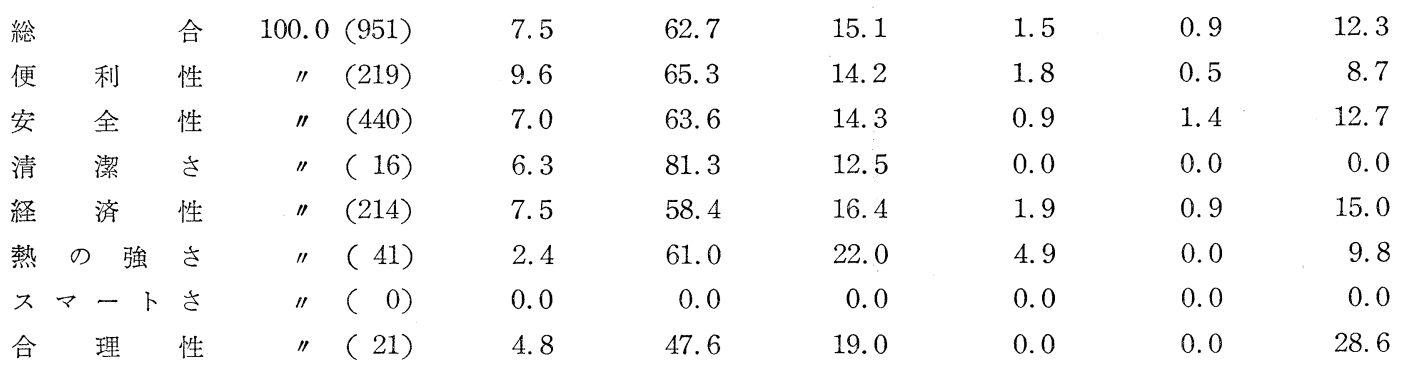

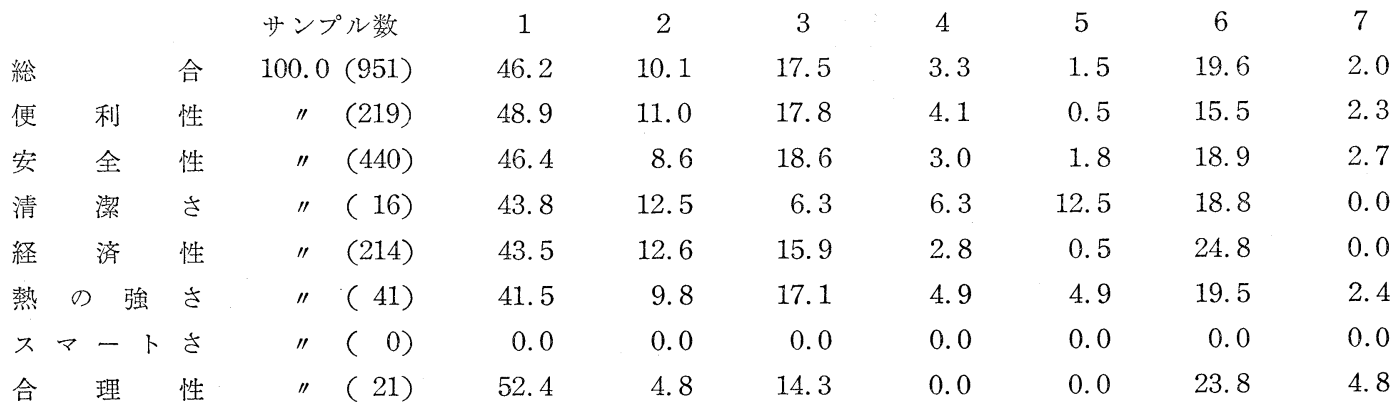

* 条件 $(1 \sim 7)$ は表 42 参照

C、世带主職業別条件*

\begin{tabular}{|c|c|c|c|c|c|c|c|c|c|}
\hline & & サンプル数 & 1 & 2 & 3 & 4 & 5 & 6 & 7 \\
\hline 総 & 合 & 100.0 (951) & 3.7 & 5.6 & 9.0 & 27.2 & 25.2 & 22.7 & 6.5 \\
\hline 利 & 性 & " (219) & 3.7 & 8.2 & 12.8 & 25.6 & 22.8 & 23.3 & 3.7 \\
\hline 全 & 性 & $(440)$ & 3.0 & 5.0 & 9.1 & 27.0 & 27.0 & 22.3 & 6.6 \\
\hline 潔 & さ & $"$ (16) & 一 & - & 12.5 & 25.0 & 25.0 & 37.5 & - \\
\hline 済 & 性 & " (214) & 4.2 & 2.8 & 5.6 & 28.0 & 25.2 & 23.8 & 10.3 \\
\hline 熱 の 強 & さ & $"(41)$ & 9.8 & 9.8 & 9.8 & 34.1 & 19,5 & 14.6 & 2.4 \\
\hline ス $>-1$ & さ & $"(0)$ & - & - & - & - & - & - & \\
\hline 合 理 & 性 & $"$ (21) & 4.8 & 14.3 & - & 28.6 & 23.8 & 19.0 & 9.5 \\
\hline
\end{tabular}

* 条件 (1〜7) は43表参照

D. 収入形態別条件*

\begin{tabular}{|c|c|c|c|c|c|c|c|c|}
\hline & & サンプル数 & 1 & 2 & 3 & 4 & 5 & 6 \\
\hline 総 & 合 & 100.0 (951) & 1.5 & 20.5 & 4.4 & 54.4 & 16,5 & 1.9 \\
\hline 利 & 性 & " (291) & 1.8 & 18.3 & 2.7 & 60.3 & 14.2 & 1.8 \\
\hline 全 & 性 & $" \quad(440)$ & 0.9 & 20.9 & 5.0 & 54.3 & 15.9 & 2.3 \\
\hline 潔 & さ & $" \quad(16)$ & - & 12.5 & 6.3 & 75.0 & 6.3 & - \\
\hline 済 & 性 & $" \quad(214)$ & 2.3 & 21.5 & 2.8 & 48.6 & 21.5 & 1.9 \\
\hline 熱 の 強 & さ & " (41) & - & 20.0 & 12.2 & 48.8 & 17.1 & - \\
\hline スマート & さ & $" \quad(0)$ & - & 一 & - & - & - & - \\
\hline 合理 & 性 & $" \quad(31)$ & 4.8 & 28.6 & 9.5 & 47.6 & 9.5 & - \\
\hline
\end{tabular}




\section{V.あとがき}

燃料協会燃焼部会ではその事業の一つして家庭燃料 の燃燒に関する小委員会が設けられた。

昭和 41 年 7 月 27 日にこの小委員会の第 1 回の会合が ひらかれた。その席上での討議の結果, 小委員会の仕 事としてはこの分野に関しての調查研究を行なうこと とし, 第一のテーマとして, 家庭燃料の燃焼の中でも とくに多様性を持ち, 問題点も多い家庭 (住居) 暖房 をとりあげることとした。

昭和 42 年 8 月 25 日に至るまで 9 回の小委員会をひら き, 各委員の提出した資料にもとづてて調查結果の分 析ならびに討議を行なつた。本報告はその結果をもと にして各委員がその専門分野についてまとめたものの 集成である。

調查に当たつては住居暖房燃料の消費量など十分に 把握できない部分す多く，また今後の住居暖房の動向 の予想といらこともほとんどなし得なかつた。

このように当初の目標からみれ涪不満な点もある が，その内容は委員の方々の非常な努力によつてまと められたものであり，少なくとも現在の段階としては 最も妥当な現状調査報告であると考えられる。また委 員会の討議を通じて今後なすべき調查研究の方向が認 識された点も大きな収穫であつた。

小委員会の構成はつぎのとおりである。

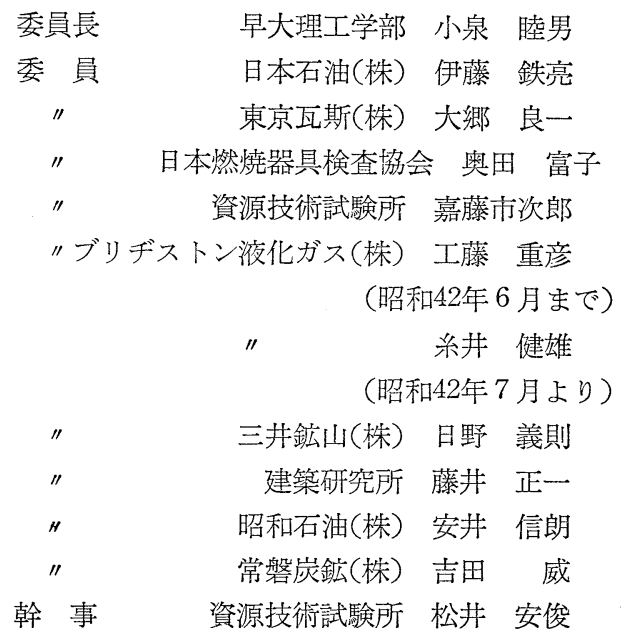

\section{文献}

1) 日野，熱と経営，北海道熱管理 (1963)

2) 石油学会(編), 石油事典, p. 516. 朝倉書店(1966)

3) A.D. Oliver, Modern Petroleum Technology, 3rd. Ed. p. 600 612 (1962)

4) D. G. Tompkins and G. F. J. Murray, J. Inst. of Petrolem, 42, 389, 129 147 (1956)

5) R. L. Weeks et al, Proceeding of 5th World Petroleum Congress, Sec IV/25 (1959)

6) J. K. P. Sloos et al, Liqurid Fuels (Domestic Utilization), Session IV of the Future of Fuel Technology (1963)

7) J. A. Bolt and D. W. Locklin, PD 30-No. 2 of the 7th world petroleum Congress (1967)

8) 嘉藤市次郎, 家庭然料の動向, 燃拹誌, 昭和各年

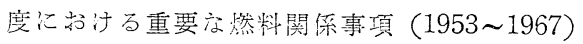

9) 日本燃焼器具検查協会資料, 石油燃燒器具 (1966)

10）安井信朗，昭石技報，3，2，57７9（1959）

11）同上, 燃協誌，44，455，133１47 (1965)

12）石油連盟，石油資料月報，12，4，251 (1967), 11，3，197 (1966)

13) 同上, 10, No. 3, p. 36 (1965)

14）鉱山局資料, 石油製品出荷性状表

15) 経済企画庁, 消費動向予測調查(1967年 2 月)

16) JIS S 2019-1965 解説

17）広瀬，織田，日本特許公告 41-10007

18） JIS S 2039-1964 解説

19) 北海道消費者協会, 家庭用暖房調查報告書 (1967 年 3 月)

20) F. W. Rakowsky et al, Conbustion and flame, 10, 2, 182 (1966)

21) 空調衛生工学会, 暧房空調 ポケットブック, p. 299 (1965)：田熊汽缶カタログ

22）嘉藤市次郎，燃協誌，44，455，p. 159

23）嘉藤市次郎, 未発表論文 